\title{
HYDROLOGY AND WATER QUALITY OF THE \\ EDWARDS AQUIFER ASSOCIATED WITH \\ BARTON SPRINGS IN THE AUSTIN AREA, TEXAS
}

By Raymond M. Slade, Jr., Michael E. Dorsey, and Sheree L. Stewart

U.S. GEOLOGICAL SURVEY

Water-Resources Investigations Report 86-4036

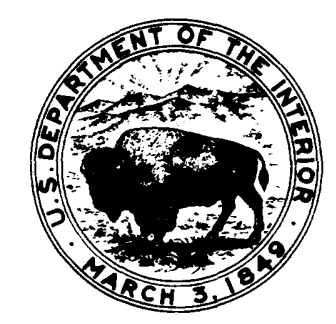

Prepared in cooperation with the CITY OF AUSTIN 


\title{
UNITED STATES DEPARTMENT OF THE INTERIOR
}

DONALD PAUL HODEL, Secretary

\author{
GEOLOGICAL SURVEY
}

Dallas L. Peck, Director

For additional information write to:

District Chief

U.S. Geological Survey

649 Federal Building

300 E. Eighth Street

Austin, TX 78701
For sale by:

Open-File Services Section Western Distribution Branch U.S. Geological Survey Box 25425, Federal Center Denver, CO 80225 


\section{CONTENTS}

Page

Abstract--1-1-1-1

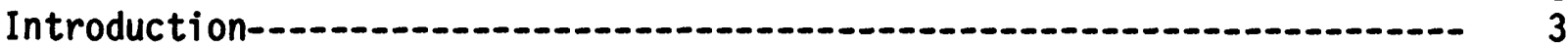

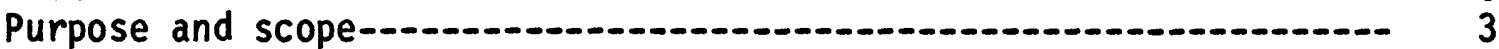

Location and extent of the study area-.............................. 5

Previous investigations-_-_. 5

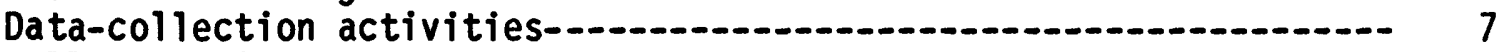

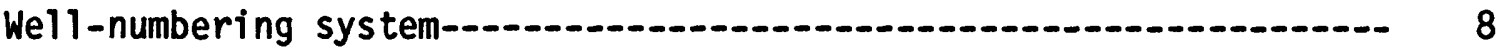

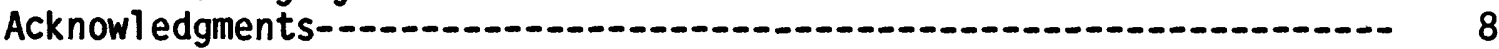

Hydrologeologic framework of the Edwards aquifer-........................ 8

Areal occurrence and thickness-....................................... 12

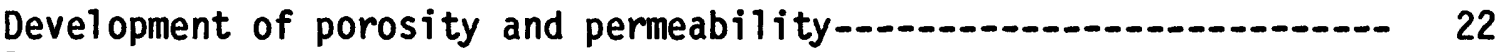

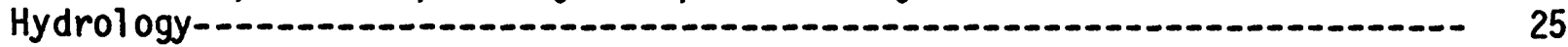

Ground-water flow system--..-...- 25

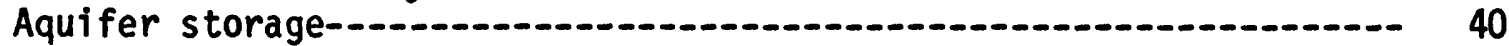

Specific yield-_._. 40

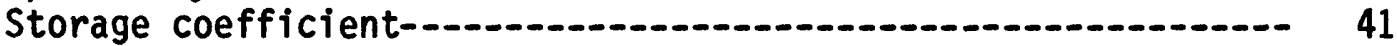

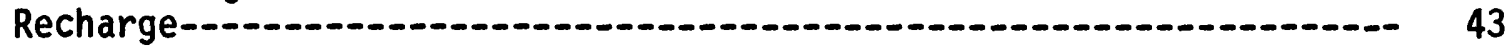

Surface recharge--............. 43

Rates and volumes-.......... 45

Potential recharge enhancement-_-_. 54

Subsurface recharge-............................................. 57

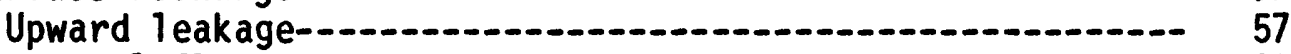

Lateral flow-...-.... 61

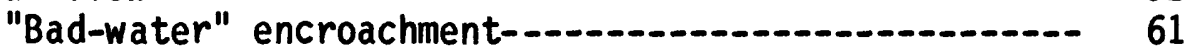

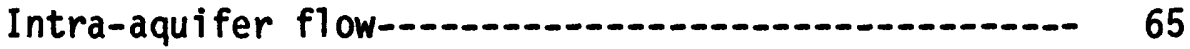

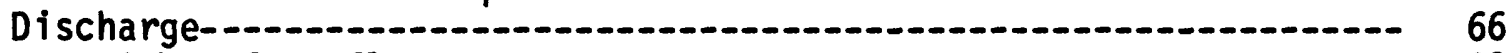

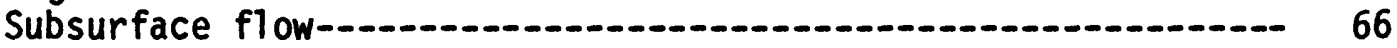

Springflow--_-_. 66

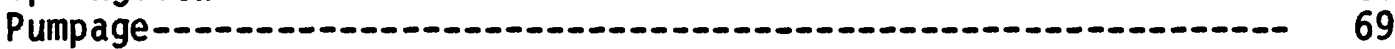

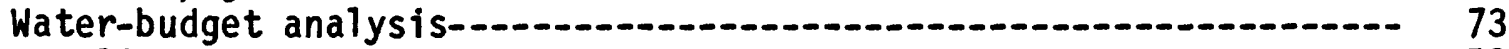

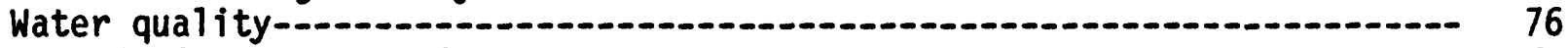

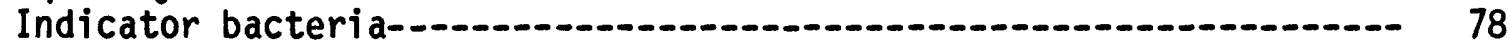

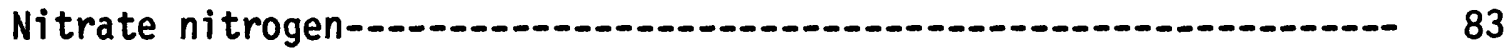

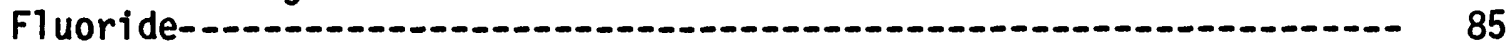

Relation of water quality of Barton Creek to water quality of

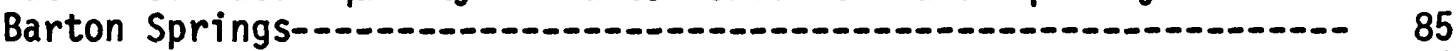

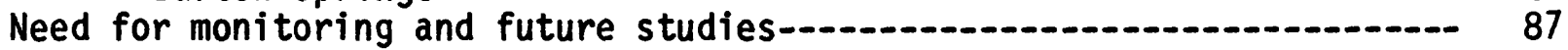

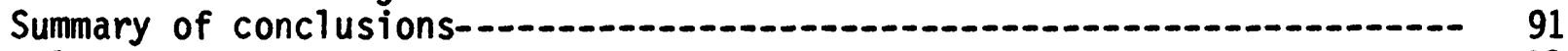

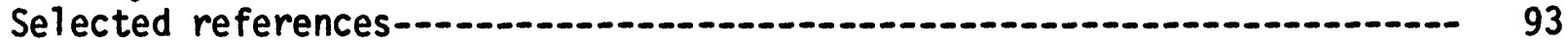

Glossary-..._.

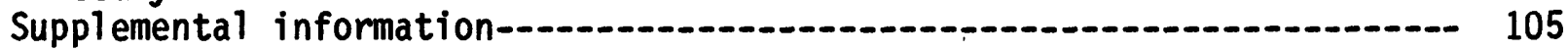


Figure 1. Photographs showing a century of devel opment of Barton

Springs, 1880's to 1980 4

2-7. Maps showing:

2. Location of the Edwards aquifer in the study area-...-..-- 6

3. Depositional province of the rocks forming the

Edwards aquifer-.--.-.--.-- 9

4. Outcrop area of the Edwards aquifer-................... 13

5. Al titude of top of Edwards aquifer...................... 16

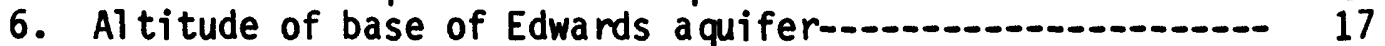

7. Thickness of Edwards aquifer-......................... 18

8-10. Hydrogeologic section of Edwards aquifer al ong:

8. Strike, A-A' -....- 19

9. Dip in Hays County, B-B'

10. Dip in Travis County, $C-C^{\prime}-\ldots$

11. Photograph of typical occurrence of 1 ateral joints and

vertical fractures in the Edwards aquifer-..-..-..-..- 23

12. Photograph of typical porous limestone comprising

the Edwards aquifer-........ 24

13. Conceptual cross section of the Edwards aquifer

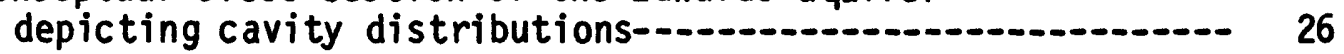

14. Map showing location of wells where water-level measurements and geologic data have been collected-_.......- 27

15. Hydrographs of water levels in wells and discharge of Barton Springs, 1979-82-_.......... 29

16. Graph showing water levels for three wells and corresponding discharges for Barton Springs-....-...-...-... 30

17-20. Maps showing potentiometric surface of the Edwards aquifer:

17. During drought of 1956

18. During low-flow conditions for Barton Springs, August

19. During average-fl ow conditions for Barton Springs, $1978-\ldots$

20. During high-fl ow conditions for Barton Springs, June 1979-_..... 34

21. Hydrographs for Barton Springs pool and four nearby well s for July 26-27, 1982

22. Map showing location of wells used to monitor the effects of changing the water 1 evel in Barton Springs pool-......... 23-25. Graphs showing:

23. Water level s for Barton Creek at Loop 360 and well YD-58-50-217 for storm of June 23, 1982

24. Precipitation, surface recharge, Barton Springs discharge, and water-level changes for well YD-58-50-216 during high-recharge period of

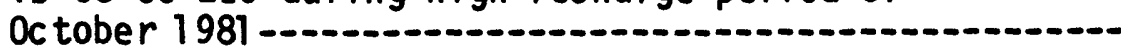

25. Relationship between Barton Springs discharge and aquifer storage-...- 


\section{ILLUSTRATIONS--Continued}

Page

Figures 26-28. Maps showing:

26. Streamflow losses in recharge area of the

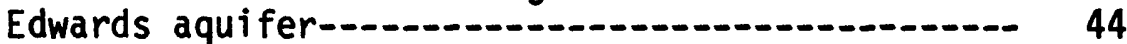

27. Surface recharge area for the Edwards aquifer-....-. 46

28. Location of streamflow-gaging stations, precipitation gages, and surface-water quality

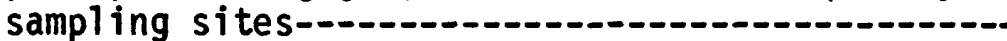

29-31. Graphs of daily precipitation, Barton Springs

discharge, and surface recharge:

29. August 1979-January 1980-_-_-_.-_ 48

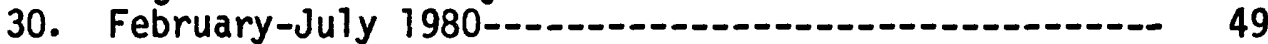

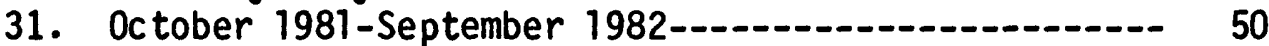

32. Graph of daily-mean values of runoff from the recharge area and surface recharge to the aquifer, May 1982-.....-. 56

33. Map showing ground-water levels in the Edwards and Trinity aquifers-

34. Map showing inorganic anions for selected wells in the Edwards and underlying aquifers-................. 60

35. Trilinear diagrams showing inorganic chemical characteristics of selected samples for Barton Springs and selected wells near the "bad-water" line for various

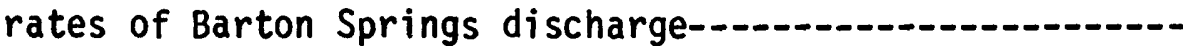
36-38. Graphs showing:

36. Relationship between water levels in well YD-58-42-903 and Barton Springs discharge--------- 68

37. Flow-duration curve for Barton Springs discharge--- 70

38. Cumulative recharge and discharge for the Edwards aquifer- location of wells where water-qual ity samples

39. Map showing location of wells where water-quality samples

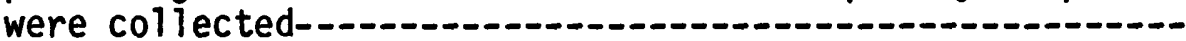

40. Graph showing fecal-coliform values with respect to precipitation for water-quality samples from Barton

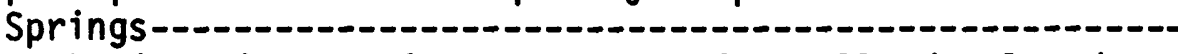

41. Map showing nitrate nitrogen values for wells developed in the Edwards aquifer-

42. Map showing fluoride values for wells developed in the Edwards aquifer

43. Graph showing turbidity of Barton Springs water following storm of May 8, 1980

44. Graph showing relation of specific conductance and discharge of water from Barton Springs to specific conductance and discharge of Barton Creek-.--.--.--.--- 
Table 1. Data-collection activities, frequency, and period of record for hydrologic investigations of Barton Springs and assoc iated Edwards aquifer-.......................... 10

2. Summary of lithology of geologic units

3. Records of wells, test holes, and springs in the Edwards

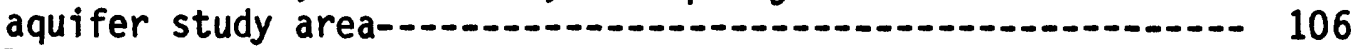

4. Calculated monthly recharge by watersheds and Barton Springs discharge for the Edwards aquifer, July 1979-

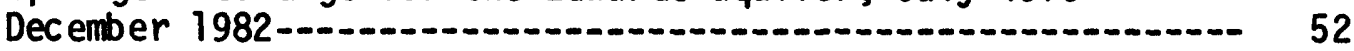

5. Dissolved-solids concentrations for water-quality samples from Barton Springs and wells near the "bad-water" line-.-.- 64

6. Monthly - and annual-mean discharges for Barton Springs, 1917-82 - Water-qual analyses for Barton Springs prior to the

7. Water-quality analyses for Barton Springs prior to
beginning of the U.S. Geological Survey sampling program in 1978-.... 79

8. Summary of standards for selected water-quality constituents and properties for public water systems-.......- 80

9. Source and significance of selected constituents and properties commonly reported in water analyses................ 114

\section{METRIC CONVERSIONS}

For readers preferring to use metric units (International System) rather than U.S. customary units, conversion factors and abbreviations for terms are listed below:

\begin{tabular}{|c|c|c|}
\hline From & Multiply by & To obtain \\
\hline $\begin{array}{l}\text { acre-foot (acre-ft) } \\
\text { cubic foot per second }\left(\mathrm{ft}^{3} / \mathrm{s}\right) \\
\text { degree Fahrenheit }\left({ }^{\circ} \mathrm{F}\right) \\
\text { foot }(\mathrm{ft}) \\
\text { foot squared per day }\left(\mathrm{ft}^{2} / \mathrm{d}\right) \\
\text { gallon per minute }\left(\mathrm{gal} / \mathrm{min}^{2}\right. \\
\text { inch (in.) } \\
\text { mile (mi) } \\
\text { pound per cubic foot }\left(1 \mathrm{~b} / \mathrm{ft}^{3}\right) \\
\text { square foot per pound }\left(\mathrm{ft}^{2} / \mathrm{lb}\right) \\
\text { square mile (mi2) }\end{array}$ & $\begin{array}{c}1,233 \\
0.02832 \\
5 / 9\left({ }^{\circ} \mathrm{F}-32\right) \\
0.3048 \\
0.09290 \\
0.06308 \\
25.40 \\
1.609 \\
16.02 \\
0.204816 \\
2.590\end{array}$ & $\begin{array}{l}\text { cubic meter } \\
\text { cubic meter per second } \\
\text { degree Celsius } \\
\text { meter } \\
\text { meter squared per day } \\
\text { liter per second } \\
\text { millimeter } \\
\text { kilometer } \\
\text { kilogram per cubic meter } \\
\text { meter squared per kilogram } \\
\text { square kilometer }\end{array}$ \\
\hline
\end{tabular}




\section{HYDROLOGY AND WATER QUALITY OF THE \\ EDWARDS AQUIFER ASSOCIATED WITH \\ BARTON SPRINGS IN THE AUSTIN AREA, TEXAS}

By

Raymond M. Slade, Jr., Michael E. Dorsey, and Sheree L. Stewart

\section{ABSTRACT}

Urban development over the Edwards aquifer in the Austin, Texas, area has caused concerns about the availability and quality of ter in the aquifer. The study area, the Edwards aquifer that discharges to Barton Springs, includes parts of Travis and Hays Counties and extends from the city of Kyle to the Colorado River. A large part of the aquifer lies within the Austin metropolitan area--one of the fastest growing areas in the Nation. As of 1985 , only about 30,000 people used water from the aquifer, however, according to recent official city of Austin population projections, about 86,000 more people will be living in the study area by the year 2000, many of whom will depend upon the aquifer for water. Barton Springs, which discharges from the aquifer, serves as a supplemental source of drinking water for Austin and as a major recreational attraction.

The aquifer is a karst system composed of limestone and dolomite of Cretaceous age. The water occurs in solution channels in the Edwards and Georgetoun Limestones. Yields of adjacent wells often differ by as much as four orders of magnitude. Storage within the aquifer is about 306,000 acre-feet, of which about 31,000 acre-feet is within the "transient" part of storage--the change in volume occurring between high flow and the lowest known flow of Barton Springs. The average specific yield of the aquifer is 0.017 .

Within the study area, the Edwards aquifer covers 155 square miles, of which about 151 square miles discharge to Barton Springs, and the remaining 4 square miles discharge to Cold and Deep Eddy Springs. The westernmost 79 percent of the aquifer is under water-table conditions, and the remaining 21 percent is under confined conditions. Three geologic sections are presented in the report, as well as maps showing the altitudes of the base and the top of the Edwards aquifer.

Recharge occurs predominantly along faults and fractures crossing six creeks in the recharge area, which covers the westernmost 90 square miles of the aquifer. Leakage probably occurs into the Edwards aquifer from the underlying upper Trinity aquifer. A small amount of subsurface recharge also occurs as "bad-water" encroachment during low-flow periods. Monthly values for water levels, total surface-water recharge, and total discharge (springflow and pumpage) for the aquifer are available for 4 years. Water-budget analyses show that surface recharge and ground-water discharge (springflow and pumpage) are reasonably balanced, suggesting that the ground-water system is in dynamic equilibrium. 
Based on 65 years of measurements, Barton Springs has a long-term mean discharge of 50 cubic feet per second and a minimum and maximum discharge of 10 and 166 cubic feet per second. As of 1982, the estimated total ground-water pumpage of about 3,800 acre-feet per year represented just over 10 percent of the average annual discharge of 36,000 acre-feet to Barton Springs. Increased pumpage associated with future ground-water development could reduce the discharge at Barton Springs and reduce ground-water availability. Substantial pumpage increases could cause increased subsurface flow into the aquifer in the form of "bad-water" encroachment, leakage from underlying aquifers, or both.

Water-quality data for 1979-83 are available for each creek that recharges the aquifer, from Barton Springs, and for 38 wells. Water quality from Barton Springs and the wells is better than the creeks providing surface recharge, which have fecal-bacteria values as high as 100,000 colonies per 100 milliliters. Significant densities of fecal bacteria have been found in water from Barton Springs. Significant concentrations of nitrate nitrogen, fecal-group bacteria, and fluoride have been identified in samples from wells. Fluoride originates in the aquifers that underlie the Edwards aquifer. Nitrate nitrogen and fecal-group bacteria originate in residential developments and cattle ranches located in the area. 


\section{INTRODUCTION}

Much of the area over the Edwards aquifer which discharges to Barton Springs is becoming urbanized rapidly. As of 1985 , about 30,000 people used the aquifer as their water supply; however, according to official city of Austin projections, about 86,000 more people will be living in the aquifer area by the year 2000, many of whom will depend on the aquifer for water. Barton Springs is located in Zilker Park near the center of Austin, and is not only a major recreational attraction for the city, but also provides water to Town Lake--a source of drinking water for the city of Austin. Depending upon the extent to which future population growth will rely on the aquifer as a wer supply, the resulting increase in ground-water pumpage could reduce the availability of ground water and could reduce or cease the discharge of Barton Springs. Much of the study area lies within the recharge area of the Edwards aquifer. Land development in the watersheds wich contribute to recharge could degrade the ter quality of the aquifer to such an extent as to limit the usefulness of the water or require chemical or physical treatment prior to use.

Barton Springs, currently the fourth largest spring in the State, has served as a source of drinking water, water power, and recreation for at least 250 years. Brune $(1975,1981)$ has documented much historical information regarding the Barton Springs area. Three Spanish missions were located by the springs during 1730 to 1731 , and a fort was established at the springs early in the 1880's. Shortly thereafter, a number of saw and grist mills and icemaking machines were constructed and used the water power of the springs (fig. 1A). In the early 1900's, Mr. A. J. Zilker purchased the 1 and around the springs and, in 1917, gave the property to the city of Austin for use as a park. Construction of a dam and sidewalks soon commenced which made the springs a popular tourist attraction (fig. 1B). Presently, Barton Springs serves as a swimming and recreational area attracting over 300,000 paid visitors annually (fig. 1C).

\section{Purpose and Scope}

The U.S. Geological Survey, in cooperation with the Texas Department of Water Resources, began hydrologic studies in the Austin area in 1954. In cooperation with the city of Austin, the program was expanded in 1975 to include an urban-hydrology study that investigated the magnitude and frequency of flood peaks, the effect of urban development and watershed characteristics on flood peaks, and the water quality of selected watersheds under urban development.

In 1978 the program was expanded further to include the study of the Edwards aquifer that discharges to Barton Springs. The general objectives of the ground-water study are to quantitatively appraise the ground-water resources of the Edwards aquifer, wich discharges to Barton Springs, and to examine and describe effects of urbanization on the quality and quantity of water in the aquifer. Four reports will address the objectives of the ground-water study. The first report described some of the effects of storm runoff on the quality of water in the Edwards aquifer and in Barton Springs (Andrews and others, 1984).

The second report concerns the hydraulic properties of the aquifer (S1ade and others, 1985). Synthesis and analysis of the hydraulic properties were 


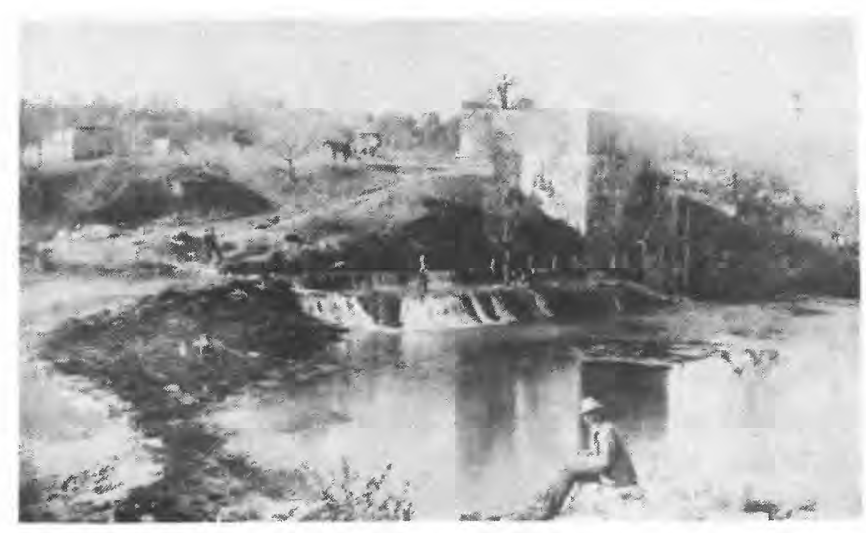

A. Mill located at Barton Springs in the 1880 decade.

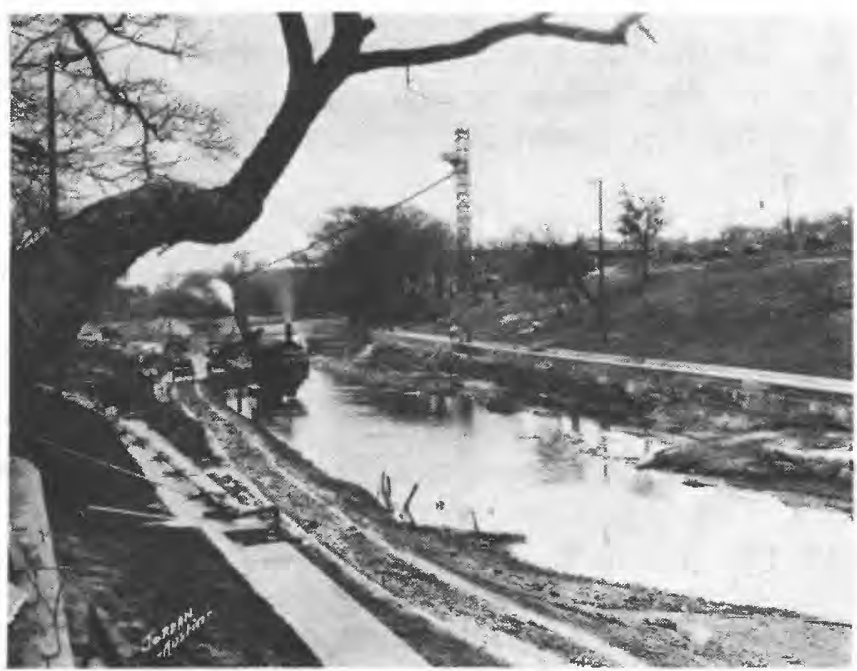

B. Construction of dam and sidewalks at Barton Springs pool in the late 1910 decade:

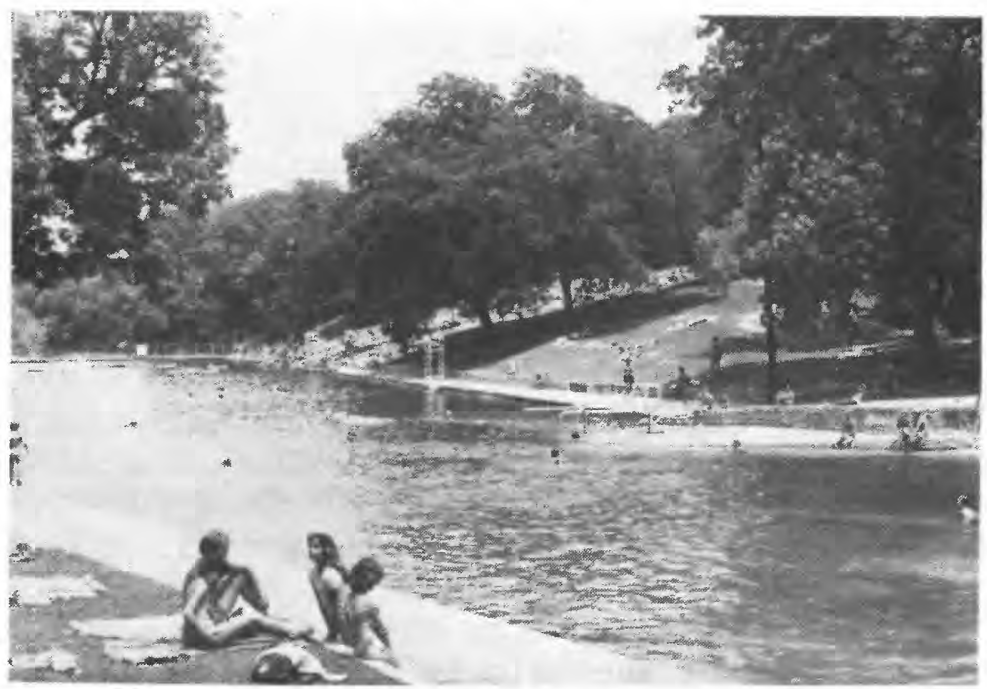

C. Barton Springs swimming pool in 1983.

Figure 1.--A century of development of Barton Springs, 1880's to 1980. Photographs A and B coutesy of Austin-Travis County Collection of Austin Public Library 
performed using a computer-simulation model of the flow in the aquifer. Simulations of present and projected water levels in the aquifer are presented in that report.

The purpose of this, the third report, is to address the following objectives for the Edwards aquifer that discharges to Barton Springs:

1. To present and evaluate the data collected to date.

2. To present the hydrogeologic framework of the Edwards aquifer.

3. To determine the boundaries of the aquifer and approximate boundaries of the recharge area.

4. To determine the quantity and quality of recharge and aquifer water.

5. To determine the quantity and quality of outflow (springflow and pumpage) from the aquifer.

6. To quantify the potential effectiveness of recharge enhancement of the aquifer.

The fourth report, which is now in preparation, will present a map of the areal extent of the recharge area in the Edwards aquifer study area. The boundaries of the recharge area are being determined by field investigations of the hydrogeologic features which influence recharge.

\section{Location and Extent of the Study Area}

The Edwards aquifer supplies at least 10 counties in central and southern Texas with water. The study area (fig. 2) includes that part of the aquifer extending from Kyle to the Colorado River. Most of the Edwards aquifer within the study area discharges to Barton Springs. The study area includes about 155 $\mathrm{mi}$ 2. The northern boundary of the study area is the Colorado River (Town Lake); the western boundary is the westernmost extent of the aquifer; the southern boundary adjoins the northern extent of the "San Antonio area" of the Edwards aquifer as designated by early ground-water investigators (Petitt and George, 1956, p. 3); and the eastern boundary is the divide between those parts of the aquifer containing water with less than and more than $1,000 \mathrm{mg} / \mathrm{L}$ (milligrams per liter) of dissolved solids. This boundary is referred to as the "bad-water" line in this report, and the area east of this line is referred to as the "bad-water" zone. West of this line, water moves readily from recharge areas to Barton Springs, and east of this line, circulation to the springs is greatly reduced.

\section{Previous Investigations}

Water-resources data in the Austin area have been gathered by the U.S. Geological Survey, the Texas Department of Water Resources, and the University of Texas at Austin, as well as other governmental agencies and engineering consulting firms during regional, county-wide, or local investigations over the past several decades.

A report by George and others (1941) contains records of wells and springs in Travis County for 1937-40. This inventory was updated by Arnow (1957), who presented additional data collected up to 1955. Brune and Duffin (1983) prepared a data and interpretive report on the occurrence, availability, and quality of ground water in Travis County, which includes updated information on wells and springs. 


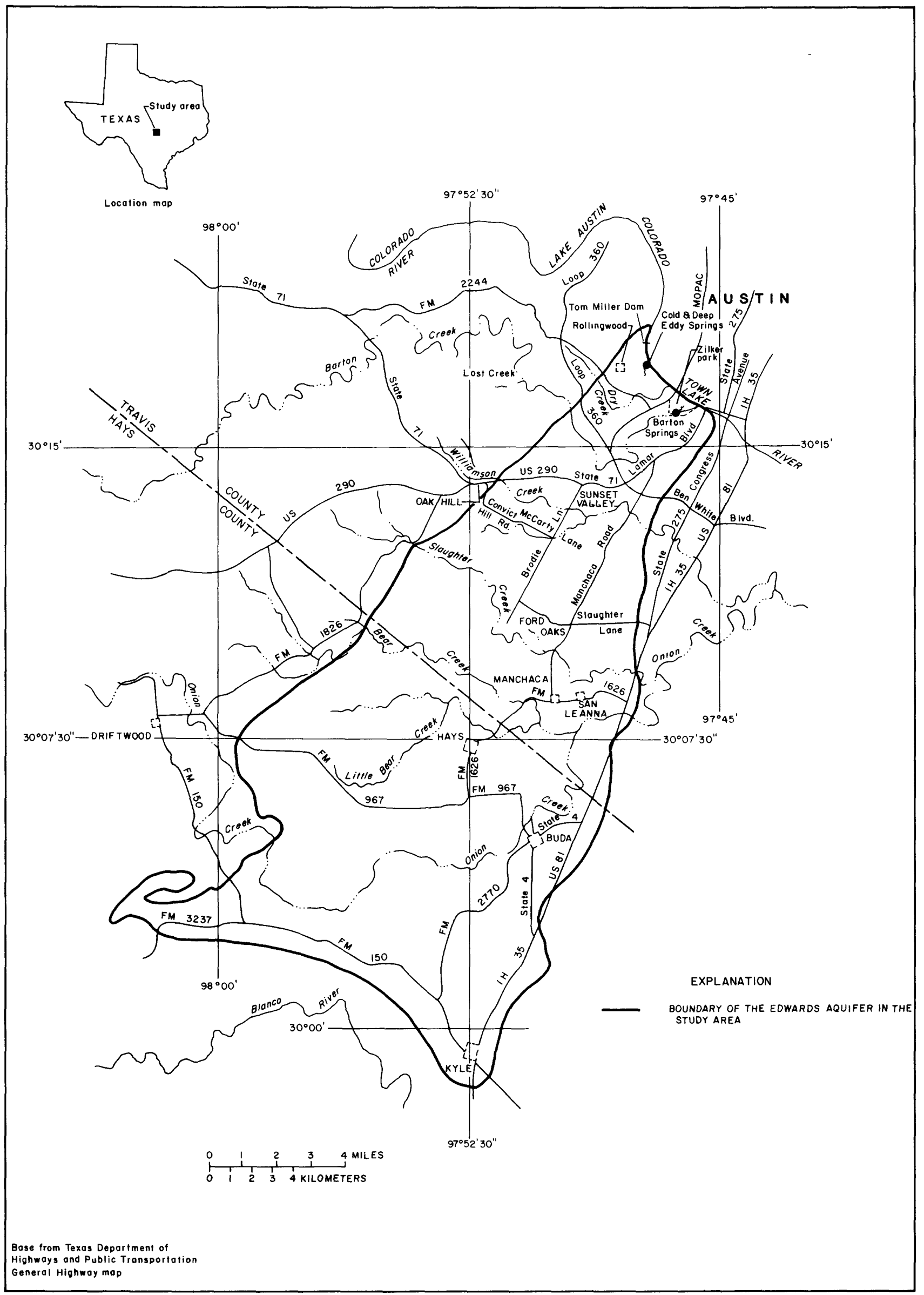

Figure 2.--Location of the Edwards aquifer in the study area. 
Barnes (1938) presented records of wells and springs collected in 1937 and 1938 in Hays County. DeCook and Doyel (1955) presented similar and supplementary data collected between 1938 and 1954. A discussion of ground water in the Edwards aquifer in the San Antonio area included data for parts of eastern Hays County (Petitt and George, 1956). DeCook (1960, 1963) presented a detailed investigation conducted from 1954 to 1956 of the geology and groundwater resources of Hays County. Ashworth (1983) presented information concerning ground-water availability of the Lower Cretaceous formations (which includes the Edwards aquifer) in Hays and other counties.

In 1978, the Geological Survey and Texas Department of Water Resources began a cooperative study of the Edwards aquifer between the cities of Kyle and Belton. Belton is about $60 \mathrm{mi}$ north of Austin. Baker and others (1986) presented a general description of the hydrologic and geologic framework of the Edwards aquifer within that study area. The report contains geologic sections and structure and thickness maps of the aquifer. Also presented in the report are the extent of water use, the potentiometric surface in January 1981 and changes in potentiometric levels, the quality of water throughout the Edwards aquifer, and interrelationships of streamflow with the aquifer. Another report from that study, now in preparation, concerns the hydraulic properties of that part of the Edwards aquifer north of the Colorado River. A steady-state simulation of the water levels, used to estimate transmissivities, will be presented in that report.

\section{Data-Collection Activities}

In order to meet the objectives of this study, an intensive data-collection program was begun in 1978. Geologic, hydrologic, water use, and water-quality data were collected and analyzed for this study and compiled from other studies. The type of data gathered for this study includes the following:

1. Geologic studies of the area were used along with drillers' logs and geophysical logs to determine the hydrogeologic framework of the aquifer.

2. Precipitation was determined from gages installed in the watersheds of the major creeks that recharge the aquifer and were used in runoff and recharge computations.

3. Streamflow-losses were determined along the creeks in order to define the distribution of recharge within the reaches.

4. Streamflow-gaging stations were located upstream and downstream from the recharge area on the major streams that overlje the aquifer, so that quantities of recharge could be determined.

5. A streamflow gage was located at Barton Springs to measure ground-water discharge, and inventories of ground-water pumpage al so were conducted.

6. Periodic water-level measurements were made in many wells and test holes in order to define ground-water level trends. Historic water levels were obtained from published reports.

7. Water samples were collected and analyzed from the major creeks that recharge the aquifer. Samples from Barton Springs and 38 wells also were collected and analyzed. Analyses of water from wells and Barton Springs were compiled from published reports.

All of the hydrologic and water-quality data collected by the Geological Survey for this program have been presented in the report series by S1ade and others $(1980,1981,1982,1983,1984)$ and Gordon and others (1985). A general 
explanation of data-collection activities, including the frequency of measurement and period of record, for the hydrologic investigations of this program are presented in table 1.

\section{Well-Numbering System}

The well-numbering system that is used in this report was developed by the Texas Department of Water Resources for use throughout the State. It is based on latitude and longitude and consists of a two-letter county-designation prefix plus a seven-digit well number. The two-letter prefix for Travis County is YD and for Hays County is LR.

Each 1-degree quadrangle in the State is given a number consisting of two digits from 01 through 89. These are the first two digits of the well number. Each 1-degree quadrangle is divided into 7-1/2-minute quadrangles which are given two-digit numbers from 01 through 64. These are the third and fourth digits of the well number. Each 7-1/2-minute quadrangle is divided into 2-1/2minute quadrangles which are given a single-digit number from 1 through 9. This is the fifth digit of the well number. Each well or spring that is located within a 2-1/2-minute quadrangle is given a two-digit number beginning with 01 , according to the order in which it was inventoried. These are the last two digits of the numbering system.

Only the last three digits of the well-numbering system are shown on the maps of the well, spring, and test-hole sites; the second two digits are shown in or near the northwest corner of each 7-1/2-minute quadrangle; and the first two digits are shown by large block numbers. For example, a well near Barton Springs that is designated $Y D-58-42-903$ is shown in figure 14 with the number 903 beside the well symbol in the 7-1/2-minute quadrangle that bears the number 42. The 1arge block number 58 designates the 1-degree quadrangle. Except for the extreme southwestern and southeastern tip, the entire study area is within this 1-degree quadrangle.

\section{Acknowledgments}

The authors are indebted to the many property owners who supplied information about their water wells and permitted access to their property. The Texas Department of Water Resources furnished numerous records of wells and ground-water pumpage information. The Public Works Department and Environmental Resource Management Department of the City of Austin provided valuable help as well as funding for this study.

\section{HYDROGEOLOGIC FRAMEWORK OF THE EDWARDS AQUIFER}

The Edwards aquifer occurs in parts of 10 counties from Kinney, in the southwest, through Uvalde, Medina, Bexar, Comal, Guadalupe, Hays, Travis, Williamson, and Bell, to the northeast. The aquifer generaliy parallels the trend of and includes the Balcones fault zone. The depositional provinces of the rocks forming the Edwards aquifer are shown in figure 3. 


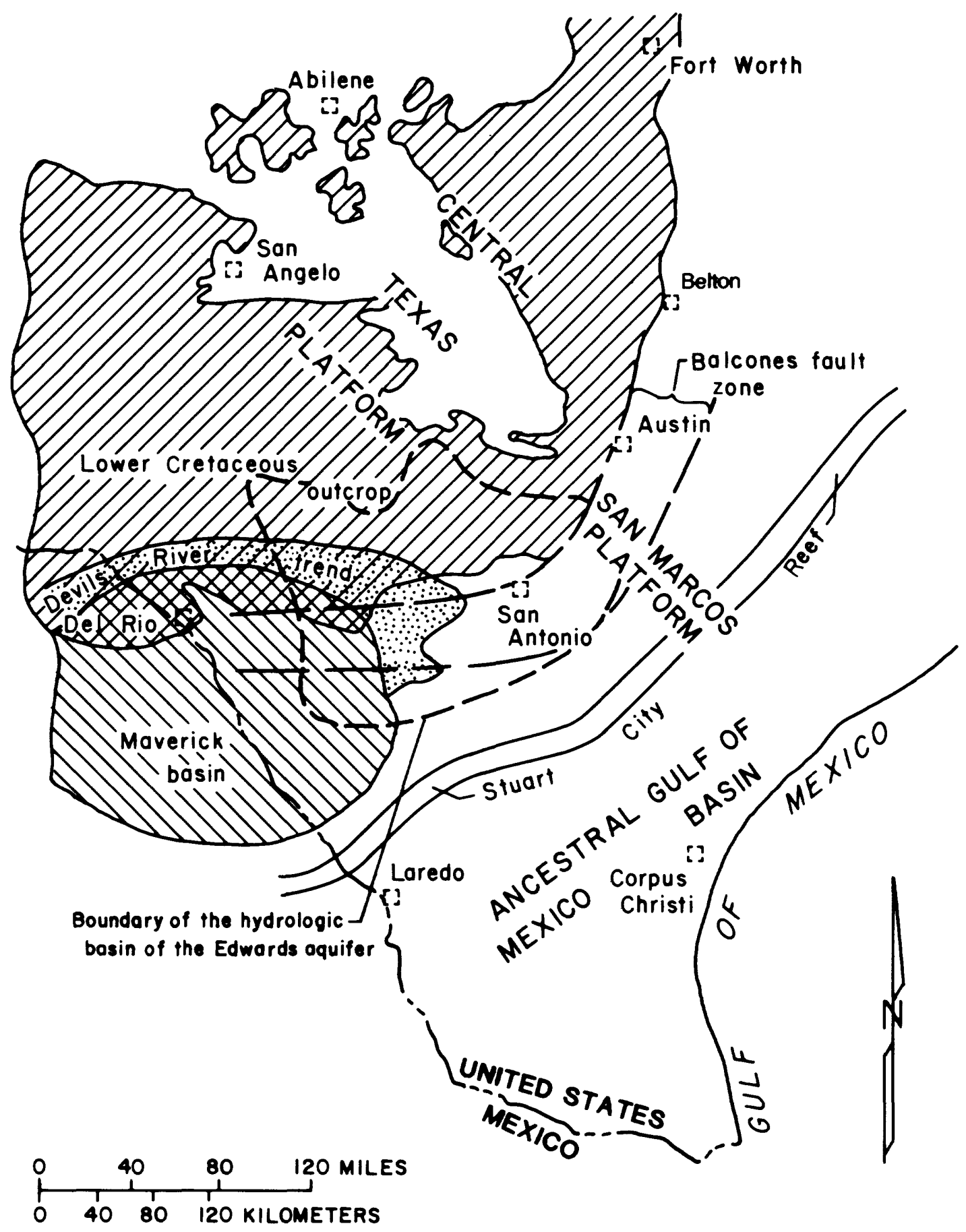

Modified from Rose (1972)

Figure 3.--Depositional province of the rocks forming the Edwards aquifer. 
Table 1.--Data-collection activities, frequency, and period of record for hydrologic investigations of Barton Springs and assoc iated Edwards aquifer

\begin{tabular}{lll}
\hline Hydrologic & Explanation & Period of record \\
investigation & $1 / 3$ \\
\hline
\end{tabular}

Recharge

quantity

Recharge quality

Rainfall records

Ground-water elevations

Ground-water quality

Ground-water pumpage

Springfiow quantity
Watersheds of six creeks provide almost all recharge. Streamflowgaging stations located upstream and downstream from the recharge zone provide quantities of recharge. Recharge period of record by watershed:
Mar. 1978 -

Jan. 1978 -

Feb. 1978 -

July 1979 -

July 1979 - Sept. 1983

July 1979 -

Jan. 1975 -

Jan. 1974 -

Jan. 1979 -

Mar. 1978 -

Nov. 1978 - Sept. 1983

Jan. 1974 -

oct. 1975 -

Oct. 1975 -

Mar. 1978 -

May 1979 -

June 1979 - Sept. 1983

May 1979 -

Water levels measured at Edwards aquifer observation wells for following number of sites and frequency:

\begin{tabular}{lc} 
Measurement frequency & Number of wells \\
\cline { 2 - 2 } Once per year (Jan.) & 72 \\
Three times per year & 57 \\
Once per month & 19 \\
Once per month & 24 \\
Hourly (recorder) & 1 \\
Hourly (recorder) & 2 \\
Hourly (recorder) & 1 \\
Hourly (recorder) & 1 \\
following constituents, number of
\end{tabular}

Ground-water samples for the following constituents, number of samples, and number of wells:

Constituent
Inorganic chemical
Bacteria, nutrients
12 minor elements
28 pesticides
Radio-chemical analysis
Radio-chemical analysis
Bacteria, nutrients, 12 minor elements
Bacteria, nutrients, 12 minor elements

\begin{tabular}{c}
$\begin{array}{l}\text { Number of } \\
\text { samples per year }\end{array}$ \\
\hline 1 \\
1 \\
1 \\
1 \\
1 \\
1 \\
3 \\
4
\end{tabular}

Number of wells

35
38
13
13
8
2
3
2

1978-83

$1978-83$

$1978,1979,1981$

$1978,1979,1981,1982$

1980

$1981-83$

1982

1982

1978-82

Jan. 1979 - Nov. 1982

Dec. 1982 - Oct. 1983

Apr. 1981 - Nov. 1981

Apr. 1981 - Sept. 1983

Apr. 1983 - Sept. 1983

Mar. 1978 -

Inventory of annual ground-water pumpage from Edwards aquifer wells reported to the Texas Department of Water Resources (TDWR) by major public supply, industrial, and irrigation users. Domestic and livestock pumpage estimated by TDWR.

$1979-82$

Discharge measurements of Barton Springs for following periods: Number of measurements

76
728
Daily-mean discharge (recorder)
Hourly and daily-mean discharges (recorder)

$1894-1910$

$1916-78$

May 1917 - Sept. 1918

Mar. 1978 - 
Table 1.--Data-collection activities, frequency, and period of record for hydrologic investigations of Barton Springs and assoc tated Edwards aquifer--Coni nued

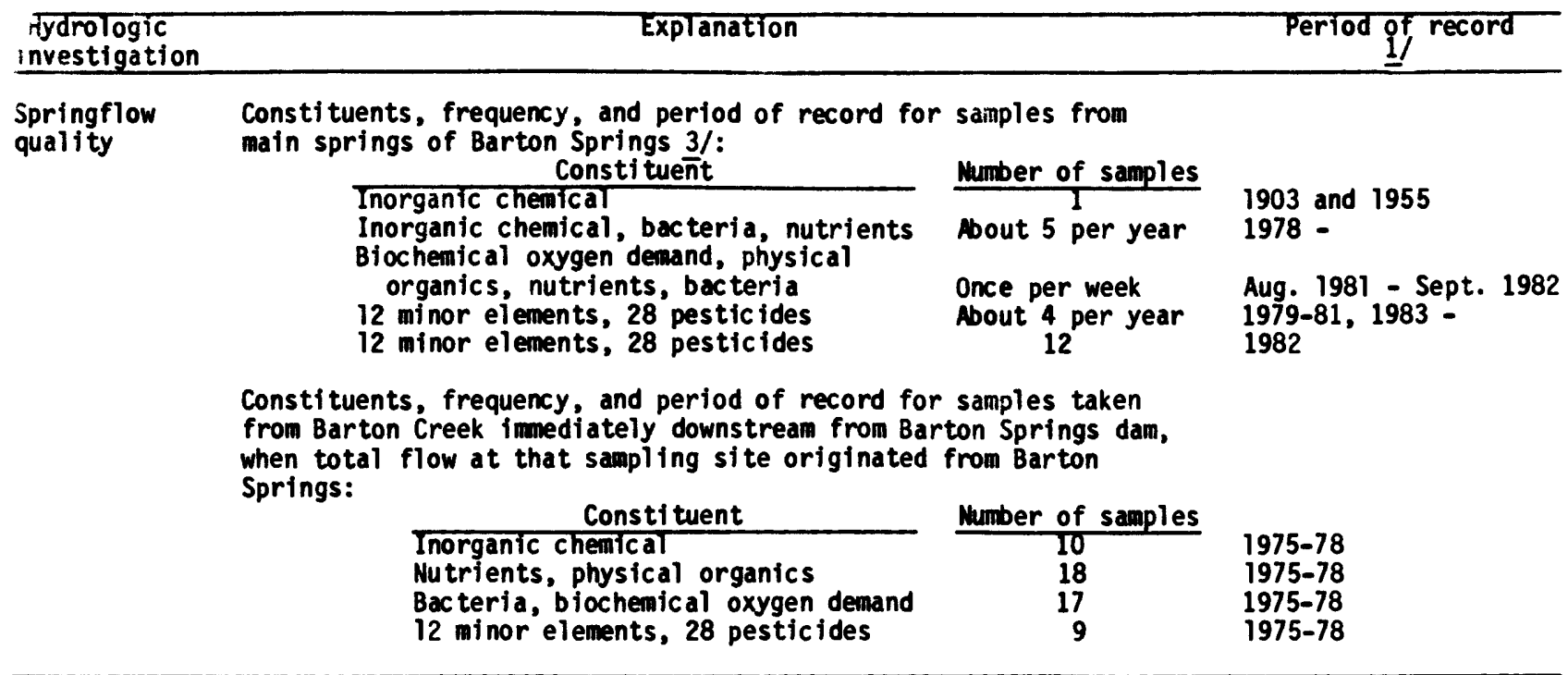

NOTE: Data frequency and period of record are generalized for this table. Except for ground-water pumpage, all data investigations listed above were collected and analyzed by the U.S. Geological Survey. This table does not include data from other sources.

$1 /$ If no ending date is given, data are still being collected.

2/ Periodic discharge measurements were made of Onion Creek at the location of tre two streamflow-gaging stations from 1961 to 1979.

3/ Water-quality analyses for Barton Springs prior to 1978 are given in table 7. 
These rocks ware deposited during the Cretaceous Period of the Mesozoic Era. The history of the Cretaceous in Texas is generally one of a gradual, intermittent encroachment of the sea wich filled the Gulf of Mexico geosyncline to the southeast. The Lower Cretaceous Edwards Limestone of the Fredericksburg Group was deposited on the Comanche Shelf. The seaward margin of this shelf was the long, narrow belt that extended northeast from Mexico to Texas and is known as the Stuart City Reef trend. The Comanche Shelf was shallow with broad depressions and swells that greatly influenced the thickness and lithology of the Lower Cretaceous units. The two most dominant depressions were the Maverick basin in the southwest and the Tyler basin in the north-northeast. The central Texas Platform separated these two depressions as a broad elongate swell bearing southeasterly from San Angelo across the Llano uplift to the Stuart City Reef. The southeastern end of this platform is known as the San Marcos Platform (Rose, 1972).

After a period of nondeposition, the marine shale and limestones of the Washita Group were deposited on top of the Edwards Limestone, followed by a period of terrigenous deposition making up the Eagle Ford Group. Carbonate deposition returned with the deposition of the Austin Group. The calcareous clay of the Taylor Group was deposited next, and finally the deposition of the marine marl and carbonaceous shale of the Navarro Group marked the close of the Cretaceous Period.

The Cenozoic Era was predominately a time of gradual withdrawal of the sea to the presert shoreline position. The Miocene Epoch is believed to be the beginning of the major movement of the Balcones fault zone. On the upthrom (northwestern) side of the fault zone, the lower part of the Edwards Limestone is the youngest unit exposed as a result of continual erosion. On the doundropped side of the fault zone, units younger than the Edwards Limestone have been preserved. The most recent geologic processes have resulted in stream dissection of the upthrom side and deposition of fluvial terraces on the downthrom side.

\section{Areal Occurrence and Thickness}

The discussion of the Edwards aquifer in the study area is limited to an evaluation of the hydrogeologic framework of the aquifer. 0ther geologic and hydrologic units that overlie and underlie the Edwards are referred to collectively as formations younger or older than those of the Edwards aquifer. Table 2 shows the formations associated with the Edwards aquifer and presents brief Iithologic descriptions of them. The stratigraphic nomenclature used in this report was taken from Rodda and others (1970), Garner and Young (1976), and Brune and Duffin (1983). The division of the lower part of the Travis Peak Formation and the Walnut Formation does not follow the usage of the U.S. Geological Survey.

The location of the outcrop of the geologic formations comprising the Edwards aquifer within the study area is shom in figure 4. The outcrop includes the Edwards Limestone and the overlying Georgetom Limestone. The rocks generally strike northward and dip gently to the east except where dip angle may be highly variable because of faulting. 


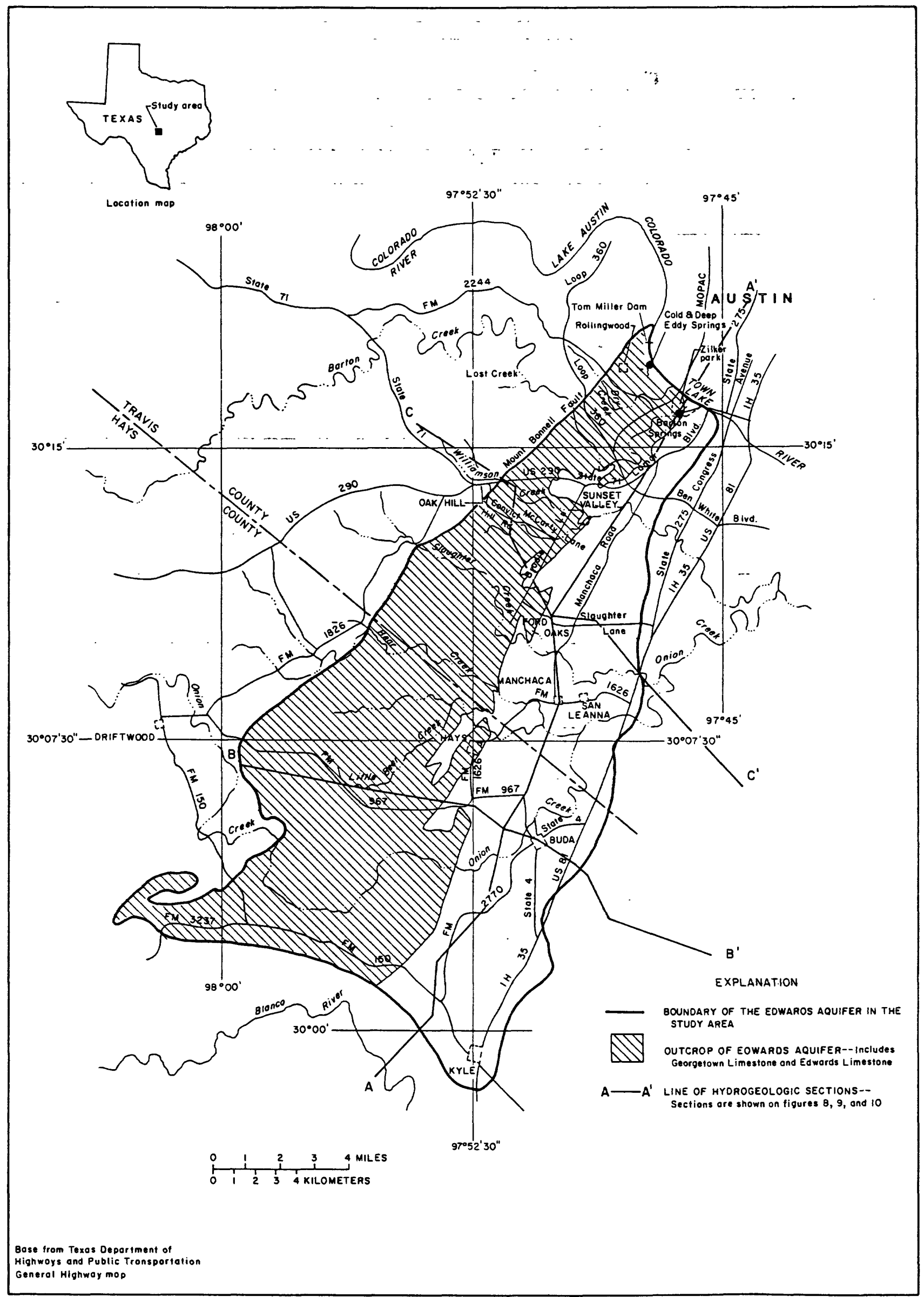

Figure 4.--Outcrop area of the Edwards aquifer. 
Table 2.--Summary of 1ithology of geologic units

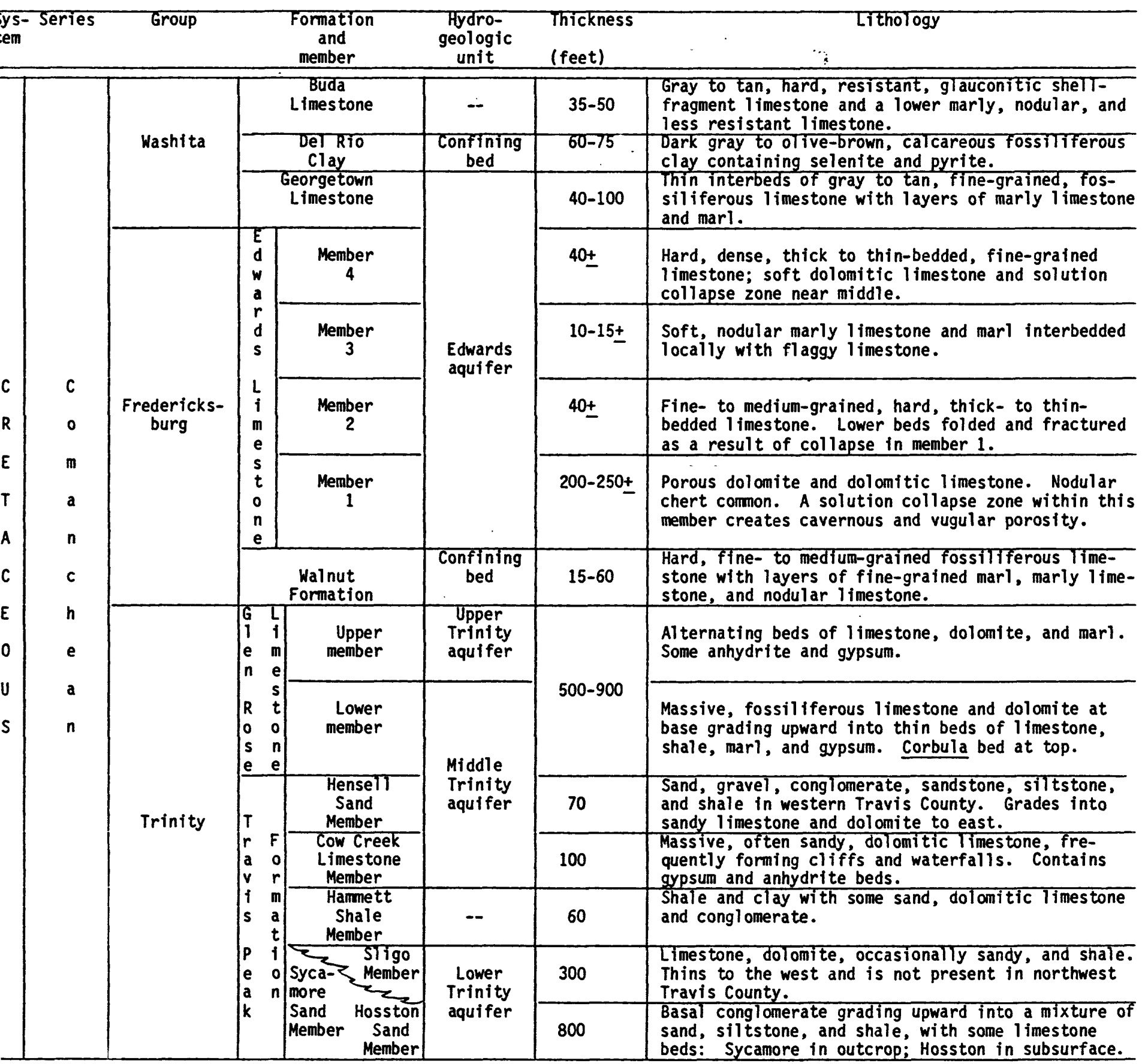

dapted from Brune and Duffin (1983, table 1), and Young (1977). 
The Edwards aquifer is underlain and bordered on the west by Cretaceous rocks older than those of the aquifer. These older rocks include from youngest to oldest, the Walnut Formation, the Glen Rose Limestone with its associated members, and the Travis Peak Formation with its associated members (table 2). All of these rocks yield relatively little water compared to the Edwards aquifer, and the water generally is more saline than water from the Edwards.

Cretaceous rocks younger than the Edwards aquifer overlie it and extend eastward on the surface. These rocks include from older to younger, the Del Rio Clay and Buda Limestone. The Del Rio Clay is relatively impermeable and forms an upper confining layer of the Edwards aquifer. Neither the Del Rio Clay nor the Buda Limestone is known to yield water in the study area.

Soils that typically are dark brown, grayish brown, silty to clayey loams have formed on the outcrop of the Edwards aquifer. These soils have developed on the underlying limestone and marl that comprise the aquifer and range in thickness from a few inches to several feet. In some places, however, soil is absent, especially on the steep slopes and where the bedrock is exposed.

Faulting associated with the Balcones fault zone can change the depth to the top of the aquifer in very short distances. The depth to the aquifer given in this report is based on interpretation of drillers' logs, lithologic descriptions, and geophysical well logs. The aquifer dips in an easterly direction as shom by the al titude of its top (fig. 5). In areas where logs are not available, the depth to the top was estimated from the altitude of the land surface at a given spot and the thickness of the geologic formations overlying the aquifer (table 2). The eroded top of the aquifer is exposed as outcrop (fig. 4). In the subsurface, the top is distinguishable on logs by a distinct change in the rock type from clay of the Del Rio to limestone of the Georgetomn.

The base of the aquifer is shown in figure 6 . The base, like the top of the aquifer, is cut by many faults. These faults cause vertical offsets along fault $\mathrm{pl}$ anes and break the continuity of the base. The offsets may be a few feet to several hundred feet and may extend laterally for miles. The base of the aquifer extends from about $100 \mathrm{ft}$ below the land surface on the western edge of the outcrop to hundreds of feet deep east of the outcrop. The base of the aquifer is less easily distinguished on the drillers' logs and geophysical well logs because the changes in lithology are not as distinct as at the top.

The thickness of the Edwards aquifer where not eroded, increases from north to south (fig. 7). The thickness varies from about $400 \mathrm{ft}$ in the northeast part of the study area to about $450 \mathrm{ft}$ in eastern Hays County. Along the eroded outcrop of the aquifer, the thickness ranges from about 100 to about 450 ft. Faulting and the extent of the erosion on the outcrop affect the thickness from place to place.

Three hydrogeologic sections are presented for the study area based on interpretation of drillers' logs, geophysical well logs, and the surface geology. The static water levels in wells during January-February 1981 al so are shown on the sections. The strike section (fig. 8) approximately follows the outcrop of the aquifer and extends from the $B 1$ anco River near Kyle in Hays County, to just north of the Colorado River in Travis County. The dip sections (figs. 9 and 10), across Hays and Travis Counties, show the position of the Edwards aquifer from its outcrop on the west doundip 12 to $15 \mathrm{mi}$ to the south- 


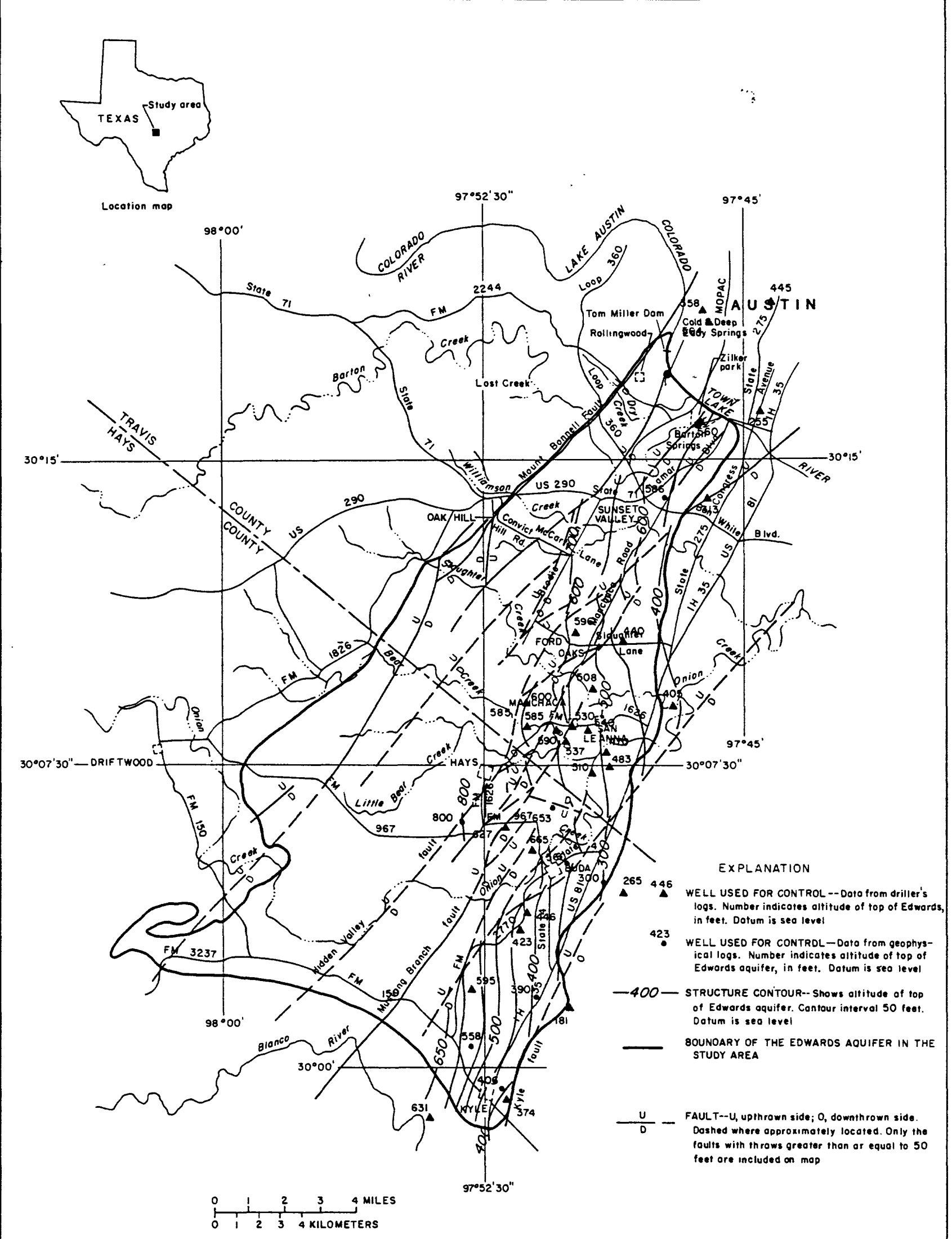

8ose from Texos Deportment of

Highwoys and Public Tronsportation

General Highway map

Faulte trom Garner and Young (1976), De Cook (1960), and Rodda and othera (1970)

Figure 5.--Altitude of top of Edwards aquifer. 


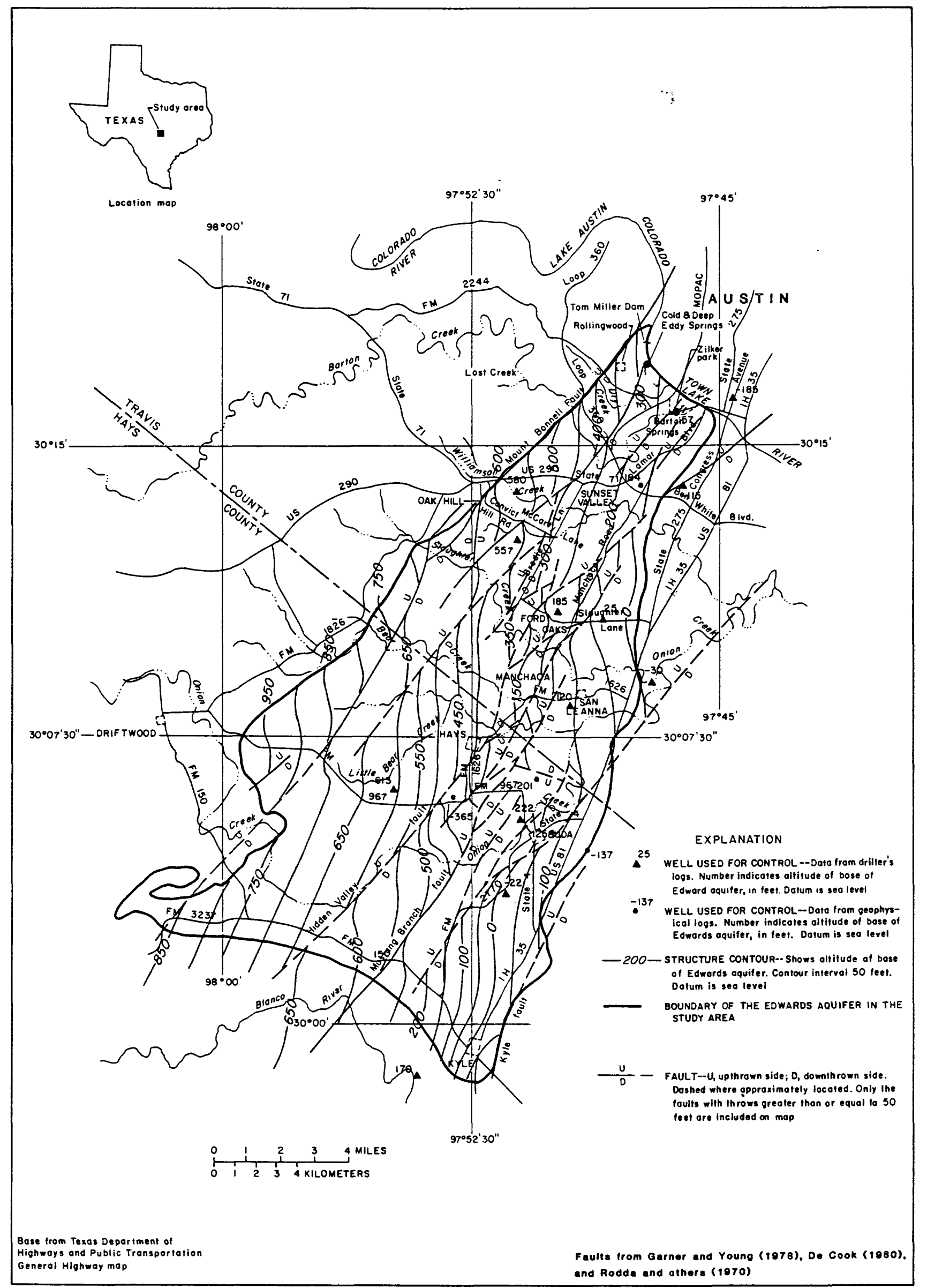

Figure 6.--Altitude of base of Edwards aquifer. 


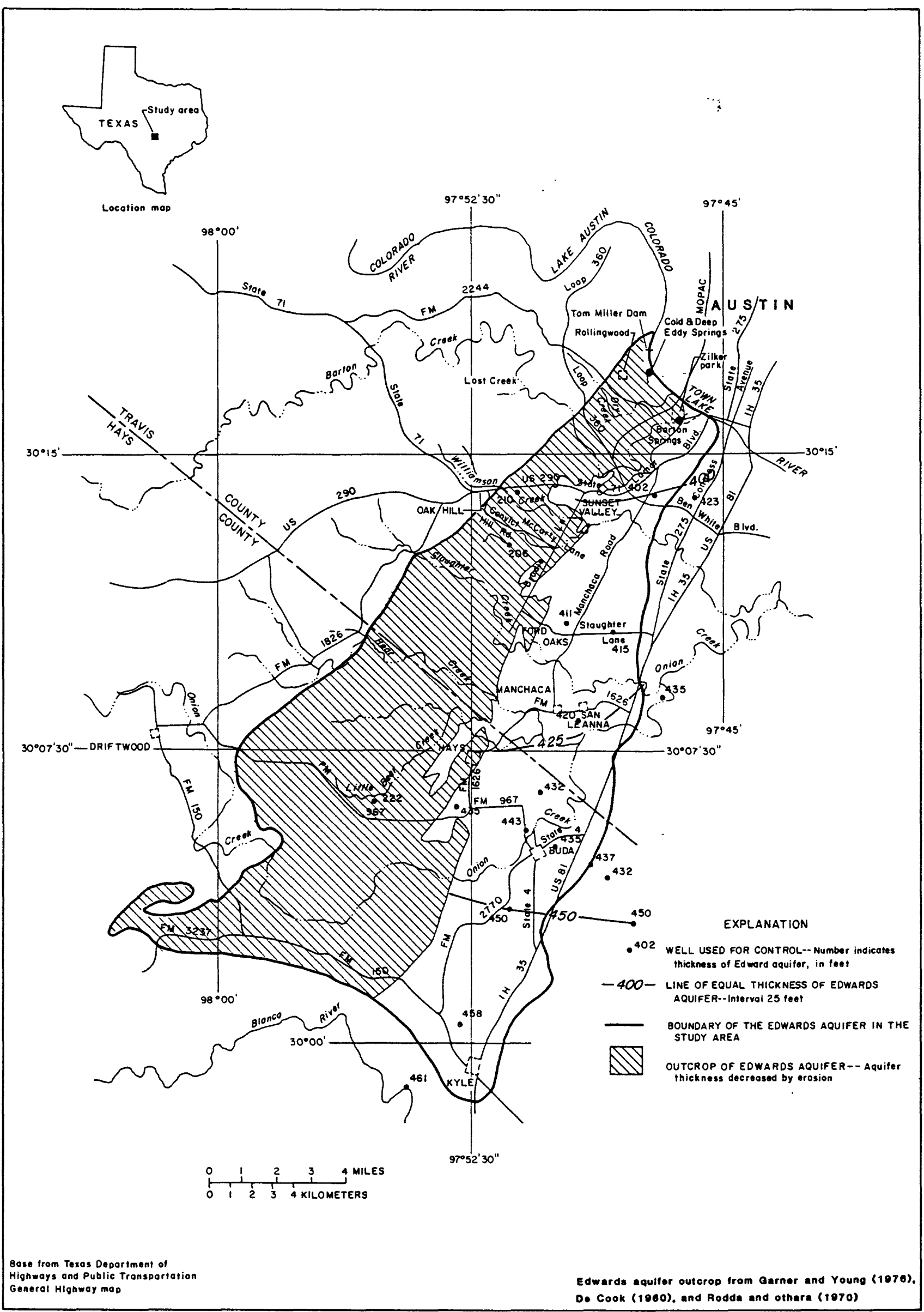

Figure 7.--Thickness of Edwards aquifer. 


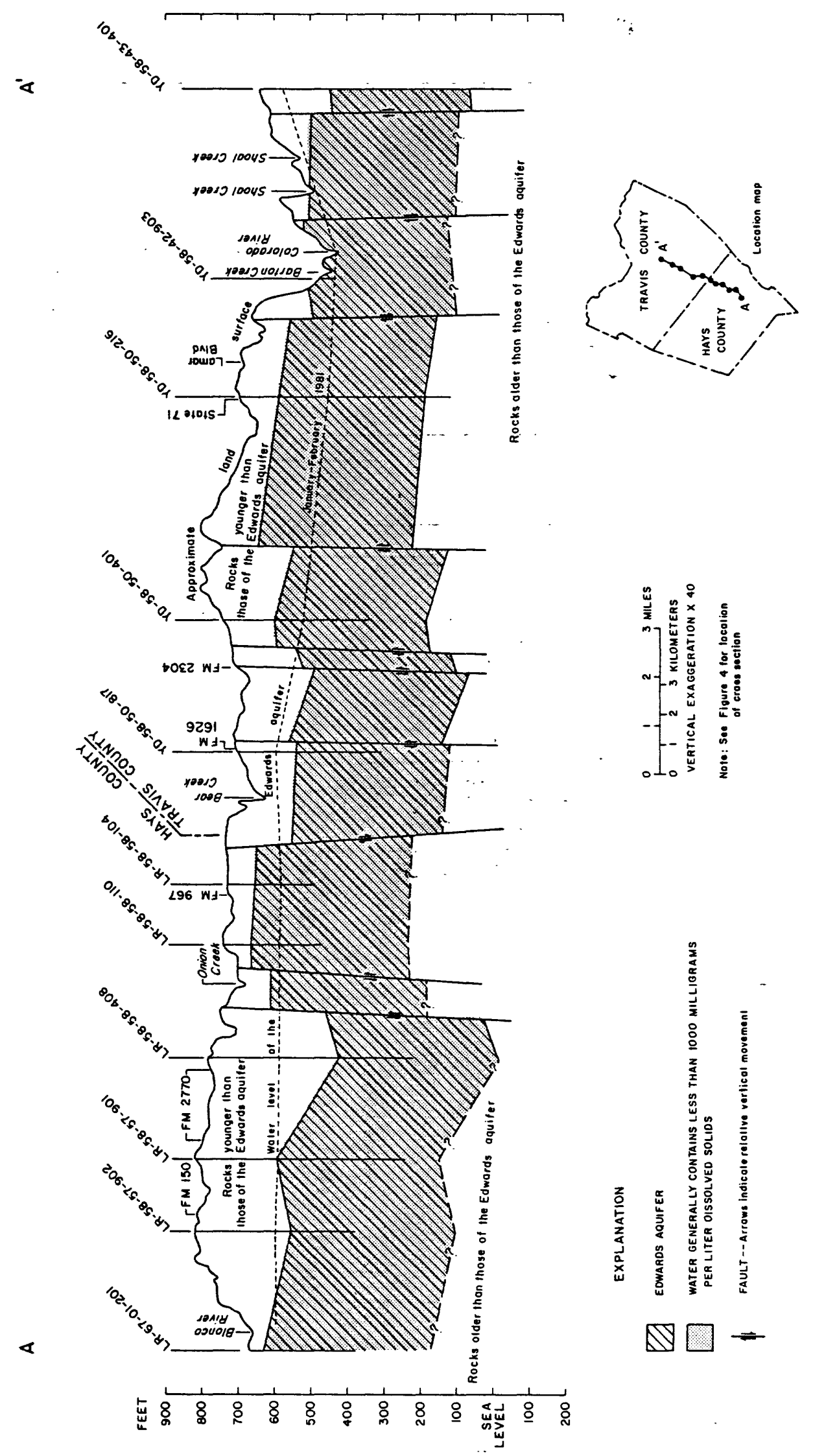




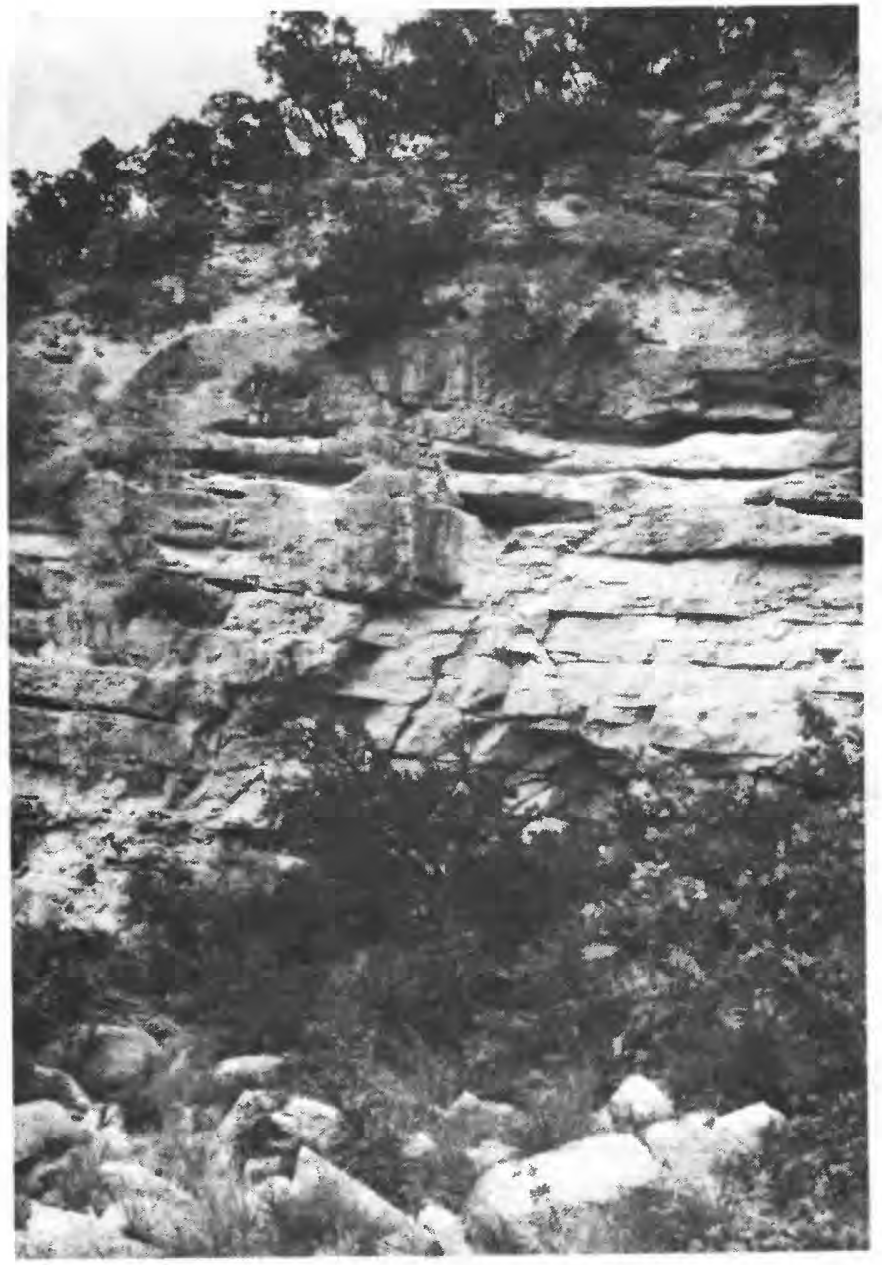

Figure 11.-Typical occurrence of lateral joints and vertical fractures in the Edwards aquifer 


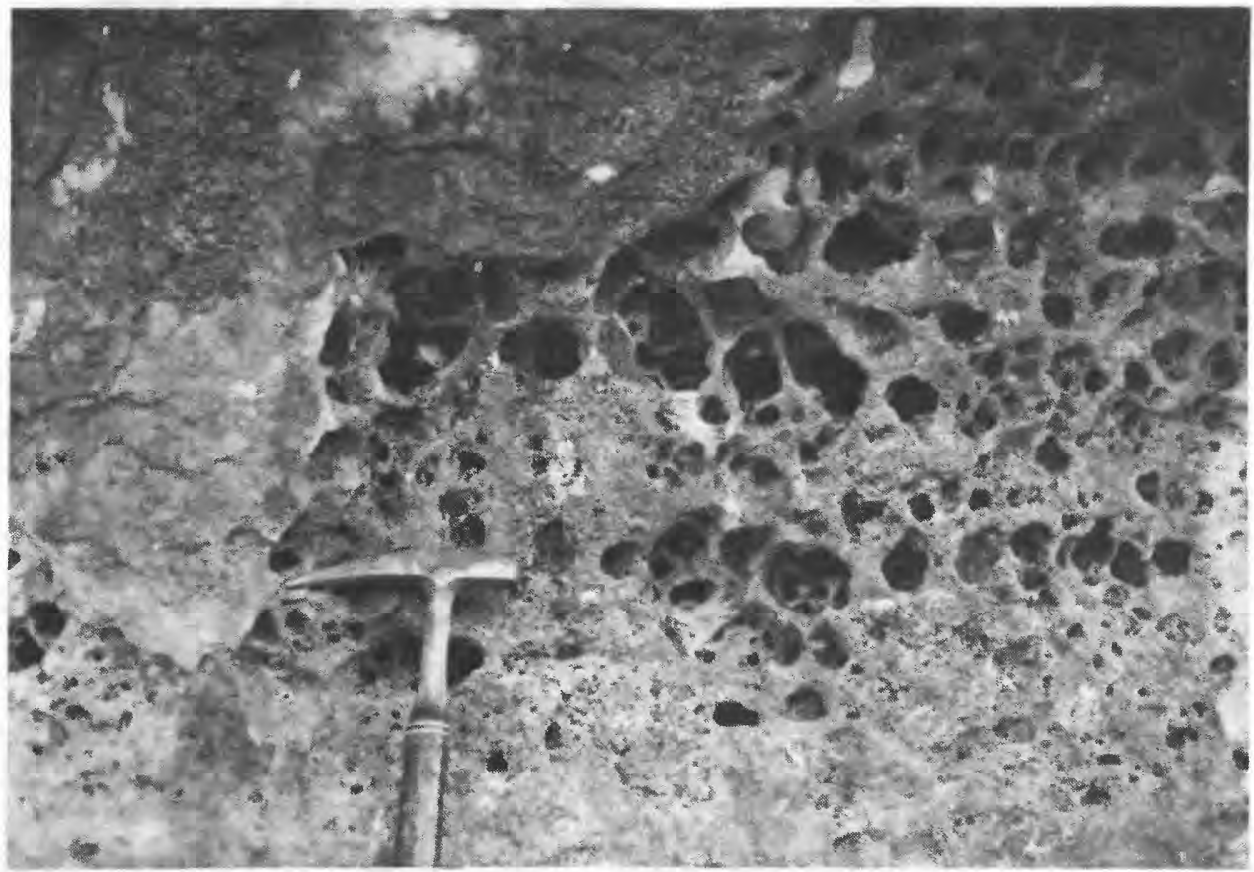

Figure 12.-Typlcal porous limestone comprising the Edwards aquifer. 


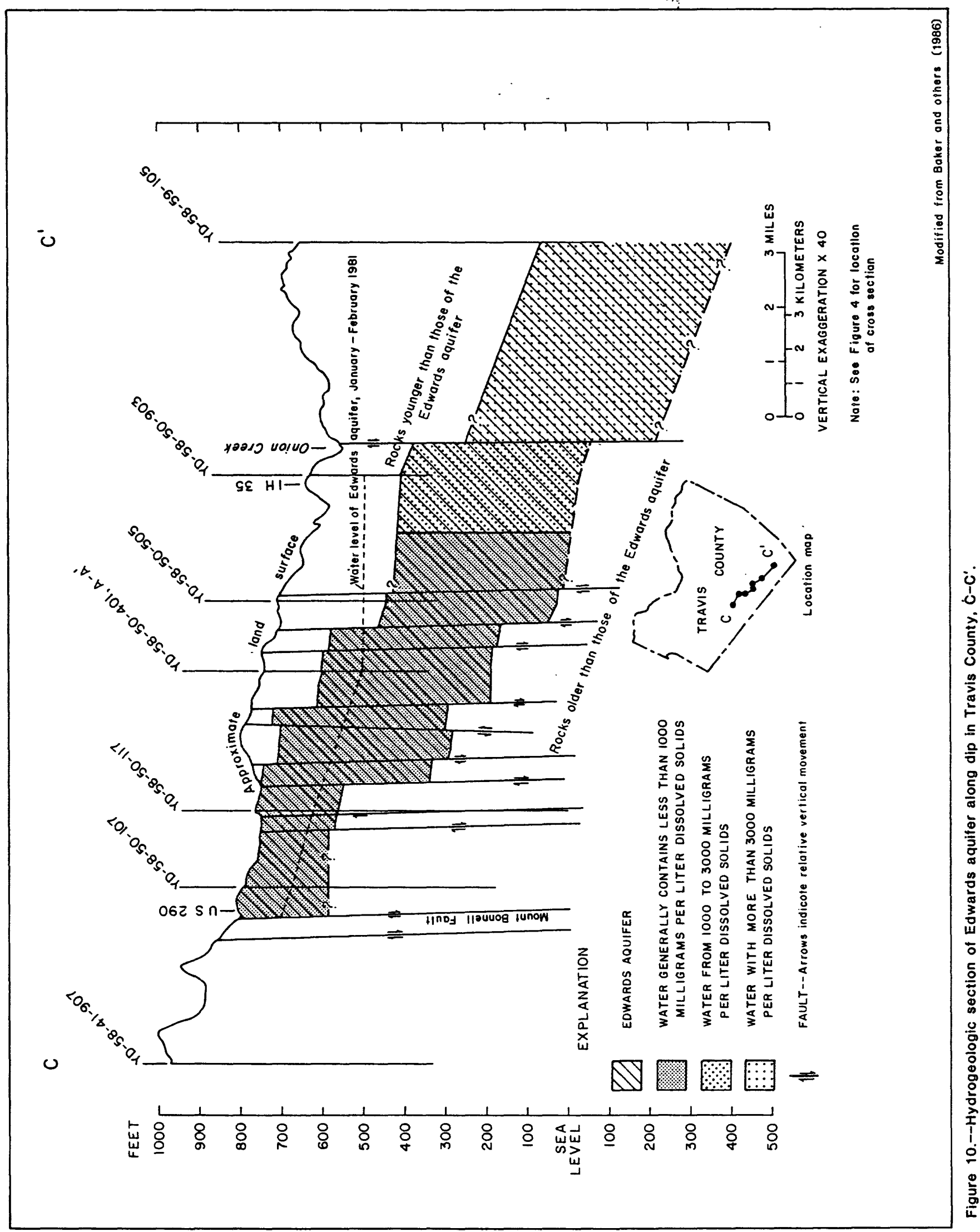

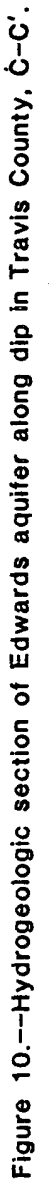


east. The dip sections show the intensity of faulting that is associated with the Balcones fault zone, which covers most of the outcrop area of the aquifer. This faulting affects the flow within the aquifer.

\section{Development of Porosity and Permeability}

Knowledge of the history and the physical and chemical changes that have occurred in the formations which now constitute the Edwards aquifer is essential to identify and describe the hydraulic characteristics. The hydraulic properties of the aquifer are greatly influenced by porosity and permeability caused by dissolution of the limestones. The processes leading to this permeability can be described by distinguishing between lateral (along bedding) and vertical (fracture) permeability. Significant lateral permeability was created through dissolution by meteoric water during an interval of exposure at the close of the Edwards Limestone deposition (Abbott, 1976). This lateral permeability is frequently coincident with zones of collapse. High-angle normal faulting, wich began during the Miocene Epoch, has affected the lateral and vertical permeability. Flow barriers are formed normal to fault traces, because lateral beds of high permeability often are separated by vertical displacement along the faults (Maclay and Sma11, 1984, p. 33). High 1ateral permeability, however, often exists along fault traces. Ground water undersaturated with respect to calcite and dolomite dissolved and increased the lateral and vertical permeability, a process wich still occurs. The vertical permeability along the faulting in the outcrop also allows surface water to enter and move through the unsaturated zone to the water table; thus, recharge to the aquifer, as well as the hydraulic characteristics, are affected by faulting and dissolution.

The creation of cavities has been enhanced by the presence of carbon dioxide $\left(\mathrm{CO}_{2}\right)$ in water (Marek, 1981). This gas combines readily with water $\left(\mathrm{H}_{2} \mathrm{O}\right)$ to form carbonic acid $\left(\mathrm{H}_{2} \mathrm{CO}_{3}\right)$, a weak acid that has the ability to dissolve limestone $\left(\mathrm{CaCO}_{3}\right)$ easily. The reaction for this process is:

$$
\mathrm{H}_{2} \mathrm{O}+\mathrm{CO}_{2} \longrightarrow \cdot \mathrm{H}_{2} \mathrm{CO}_{3}
$$

water carbon dioxide carbonic acid

Dissolving 1 imestone produces calcium ions $\left(\mathrm{Ca}_{++}\right)$and bicarbonate ions $\left(\mathrm{HCO}_{3-}\right)$. The formula for this process is:

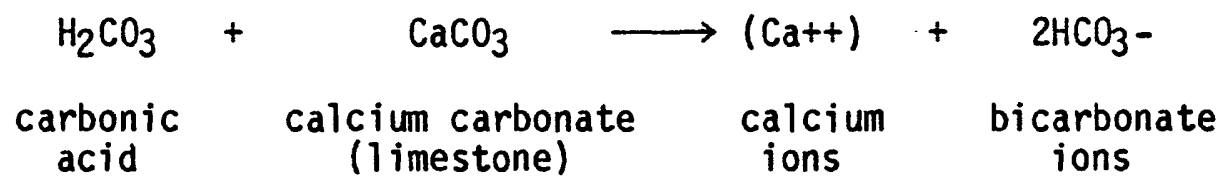

Flow in the aquifer is primarily through the cavities and caves associated with faults, fractures, and joints, and secondarily through porous media within the limestone. Examples of a fracture system and a porous system are shown in figures 11 and 12, respectively. These two illustrations are photographs of the banks of Barton Creek, taken about $0.5 \mathrm{mi}$ and 0.75 mi upstream from Barton Springs.

Analyses were made of caliper logs and drillers' logs for 79 wells in the study area. The logs for 49 of the 79 wells showed at least one cave or cavity 
to be present within the saturated zone of the aquifer. Over one-half of these 49 wells were drilled very close to known faults. Of the $30^{\circ}$ wells for which no cavities were found, only 8 were close to known faults. This evidence, while not conclusive, supports the theory that many of the cavities within the aquifer are associated with faults that are prevalent in the study area. The cavities noted in this study were analyzed with reference to four factors: the altitude of the cavities; the cavity depths below land surface; the vertical position of the cavities with respect to the base of the aquifer; and the depth to the cavities below the potentiometric surface of the aquifer. No significant correlations of the cavities with respect to those four factors could be defined, implying that stratigraphic control of the cavities was not significant.

A concept of how water occurs in the Edwards aquifer is presented in figure 13. Water from the land surface enters the aquifer at faults, fractures, and associated cavities that intersect streams where the Edwards aquifer is exposed at the surface, and moves through the aquifer through distinct vertical and lateral channels that vary in size. The permeability is not uniformly distributed throughout the aquifer, and thus wells that penetrate the caves and cavities in the aquifer generaliy produce large yields of water, while wells that do not penetrate the large cavities tend to have small yields. The difference in yields between nearby wells may vary by several orders of magnitude. Transmissivity values, calculated from specific-capacity determinations of 60 wells, range from 3 to about $47,000 \mathrm{ft} / \mathrm{d}$ (S1ade and others, 1985).

\section{HYDROLOGY}

The hydrologic and water-use data that were collected or compiled from other studies were used to determine and evaluate the hydrologic characteristics of the Edwards aquifer in the study area. Information concerning the ground-water flow system, aquifer storage, recharge, and discharge from the aquifer are presented in this section. The hydraulic properties of the Edwards aquifer in the study area are presented by Slade and others (1985). Values for transmissivity, hydraulic conductivity, and specific yield, determined for grid cells representing the study area, are presented in that report. These hydraulic properties were determined by using ground-water levels, recharge, and discharge to calibrate a mathematical model that simulates flow in the aquifer.

\section{Ground-Water Flow System}

Potentiometric maps indicate the general direction of ground-water movement and, together. with hydrologic properties, provide a measure of the amount of water in storage. Altitudes of ground-water levels were determined for the study area by measuring the depth of water levels in wells throughout the aquifer and relating them to sea level. The altitude of the land surface at each well was taken from topographic maps published by the U.S. Geological Survey. Beginning in 1979, about 19 wells in the Edwards aquifer were measured monthly, and beginning December 1982, 24 wells were measured monthly. The monthiy measurements were discontinued in 0ctober 1983. About 72 wells were measured once a year, usually in January, from 1978 to 1982 . All the water-level measurements from these wells are published each year in the annual report series by Siade and others $(1980,1981,1982,1983,1984)$ and Gordon and others (1985), and the locations of these wells are shown in figure 14. Also shown in this illustra- 


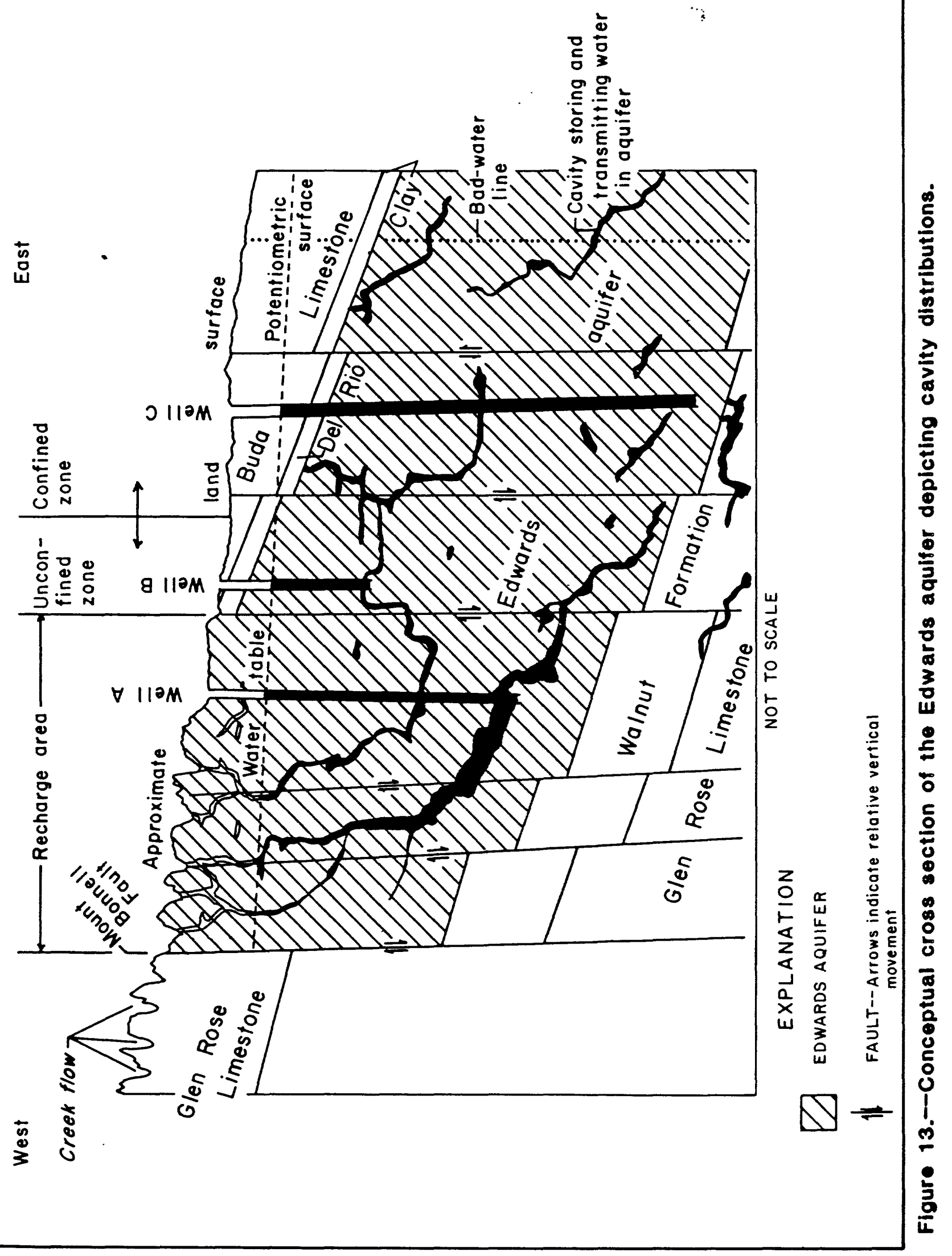




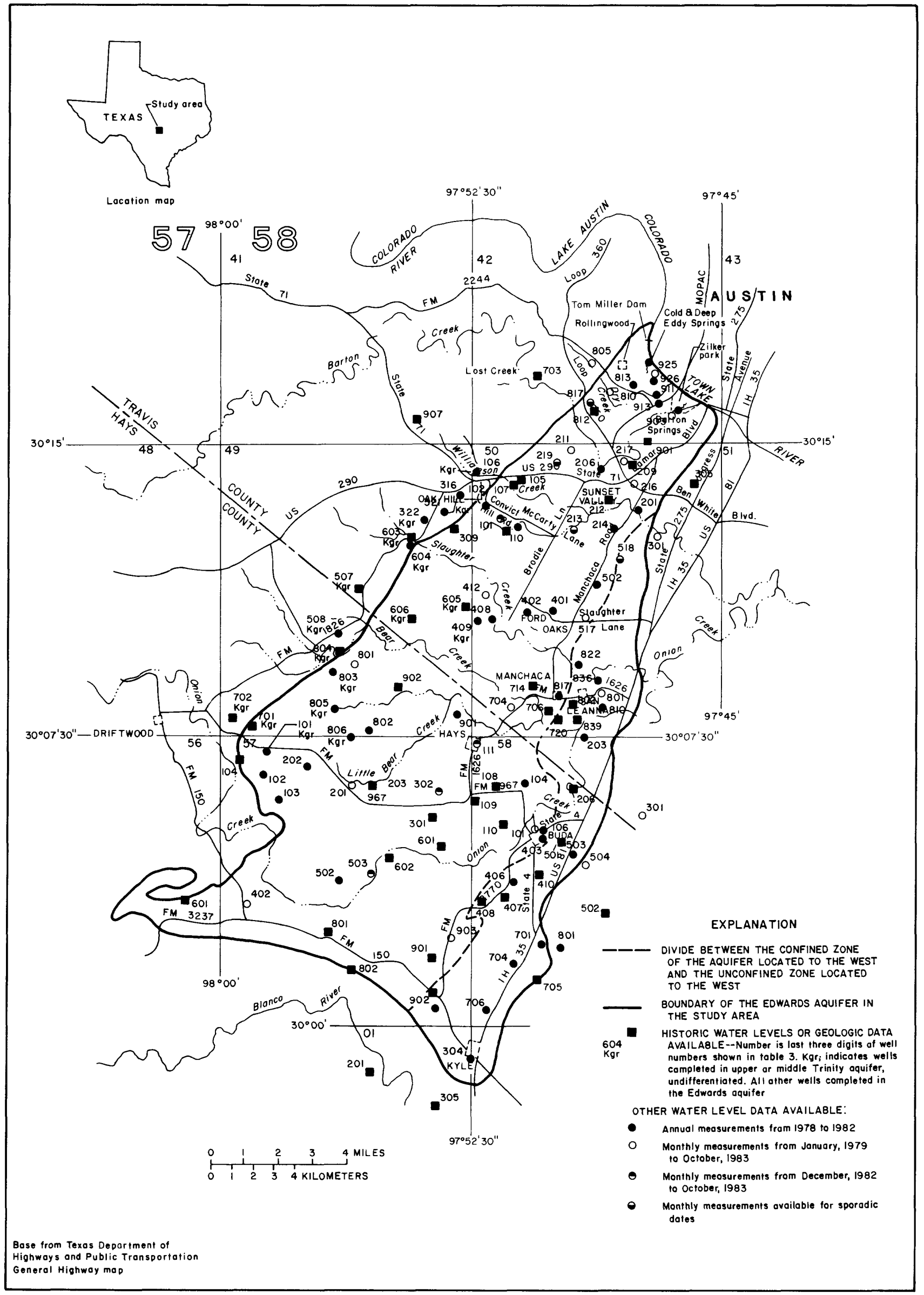

Figure 14.--Location of wells where water-level measurements and geologic data have been collected. 
tion are the areas characterized by confined and unconfined conditions in the aquifer. Other wells in the study area that have provided historic water-level data and geologic information also are shown in figure 14. Selected information for these and other wells in the study area are presented in table 3 (supplemental information).

Hourly water-level recorders were installed on several wells to document ground-water fluctuations during high-recharge periods. A recorder has been installed on well YD-58-42-903 since March 1978. Recorders on four other wells have provided records of hourly water levels for periods ranging from a few weeks to about 2 years. The wells include YD-58-42-915, YD-58-50-216, $Y D-58-50-217$, and $Y D-58-50-518$ (fig. 14). Water levels from some of these wells are presented in this section.

Water-level hydrographs for three of the monthly observation wells and the discharge hydrograph for Barton Springs are presented in figure 15 . The three wells, LR-58-57-903, YD-58-50-704, and YD-58-50-216, are located in the southern, central, and northern parts of the study area (fig. 14). The relationship between the monthly water levels for the three wells, as presented in figure 15, and the corresponding discharge at Barton Springs at the time of the measurements is shown in figure 16. As these two illustrations show, the trends of water levels throughout most of the aquifer are very similar and correlate directly with discharges for Barton Springs.

Potentiometric surfaces for the Edwards aquifer during drought, lowdischarge, average-discharge, and high-discharge conditions are shown in figures 17 to 20, respectively. Aquifer conditions during a severe drought in 1956, when Barton Springs was discharging $10 \mathrm{ft}^{3} / \mathrm{s}$ (the minimum observed discharge since 1894), are shown in figure 17. Aquifer conditions in August 1978, when the discharge of Barton Springs was about $22 \mathrm{ft}^{3} / \mathrm{s}$, a flow that is exceeded about 84 percent of the time, are shown in figure 18. The discharge at Barton Springs in January 1981 was approximately equal to the long-term mean discharge of $50 \mathrm{ft}^{3} / \mathrm{s}$. The potentiometric surface of the aquifer at this time is shown in figure 19. The potentiometric surface, as shown in figure 20 , represents conditions in June 1979, when the discharge of Barton Springs was $105 \mathrm{ft}^{3} / \mathrm{s}$, a flow exceeded only about 3 percent of the time. Comparing ground-water altitudes for these four conditions shows that the greatest water-level fluctuations occur in the eastern part of the aquifer, where it is confined.

As of 1982, no trends of ground-water declines had been identified because of pumpage increases, thus the fluctuations identified in this report are believed to be caused by variations in recharge only. Generally, water-level fluctuations between high- and low-flow conditions increase from the western to the eastern part of the study area. They are about 2 to $15 \mathrm{ft}$ (except near Barton (reek where the range is greater) in the western part of the study area, 10 to $50 \mathrm{ft}$ in the central part, and 40 to $90 \mathrm{ft}$ in the eastern part. Maximum water-level fluctuations for selected wells developed in the Edwards aquifer are presented by Slade and others (1985, fig. 4). Lines perpendicular to the potentiometric contours indicate general directions of ground-water movement. Ground water flows toward Barton Springs by moving initially to the east and then north to the springs. Ground water from recharge throughout most of the aquifer converges to the common discharge point at Barton Springs. 


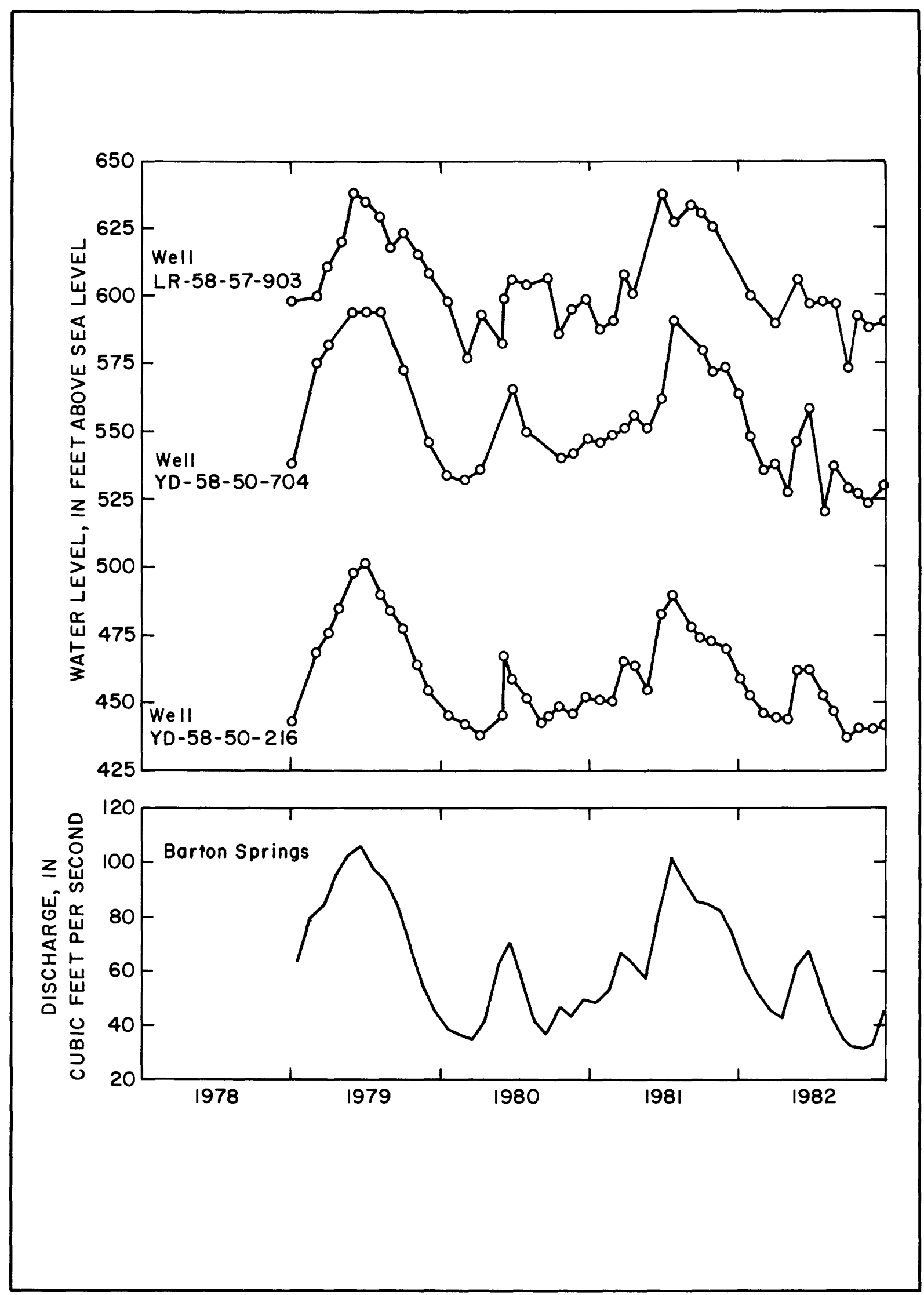

Figure 15.--Hydrographs of water level in wells and discharge of Barton Springs, 1979-82. 


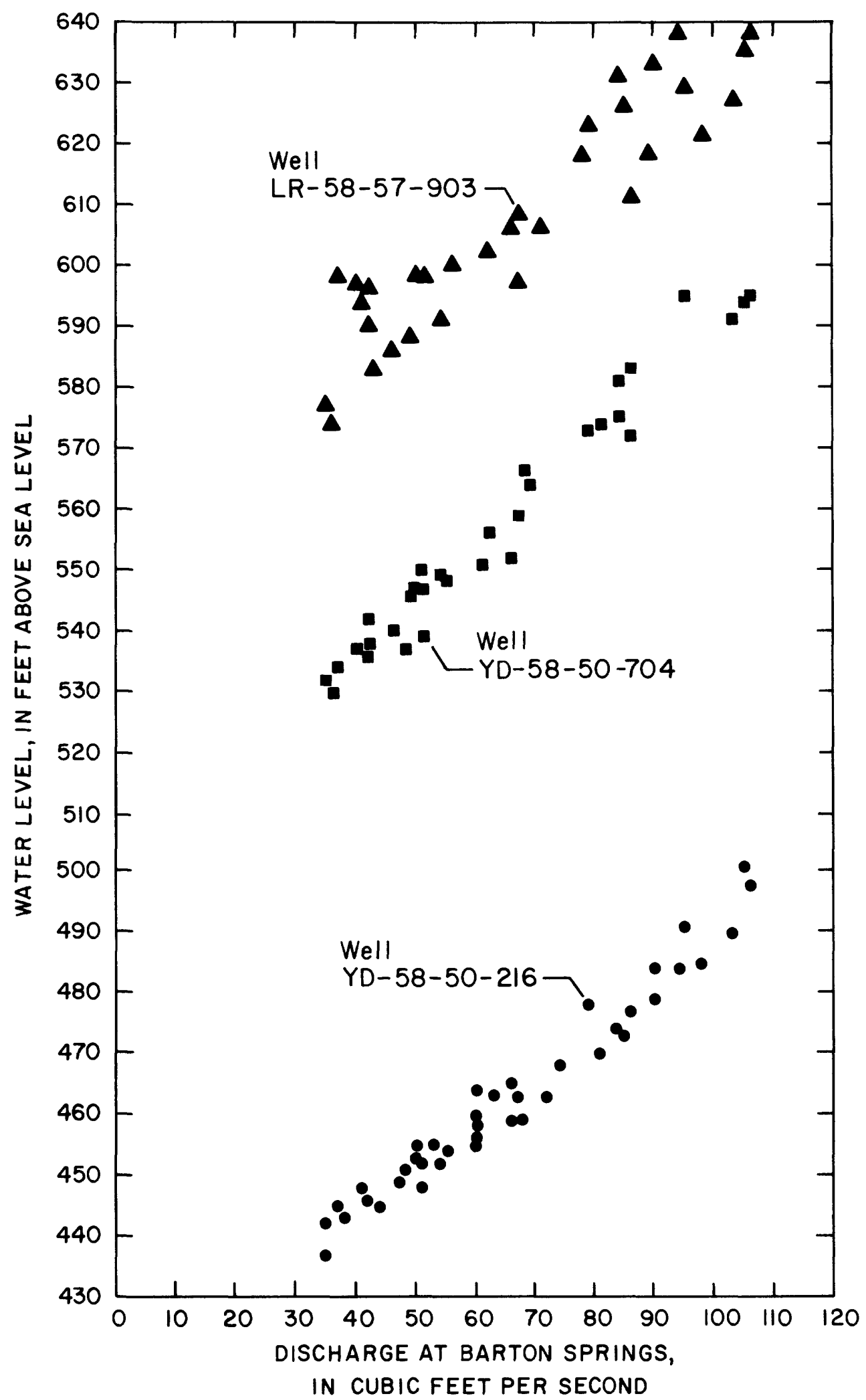

Figure 16.--Water levels for three wells and corresponding discharges for Barton Springs. 


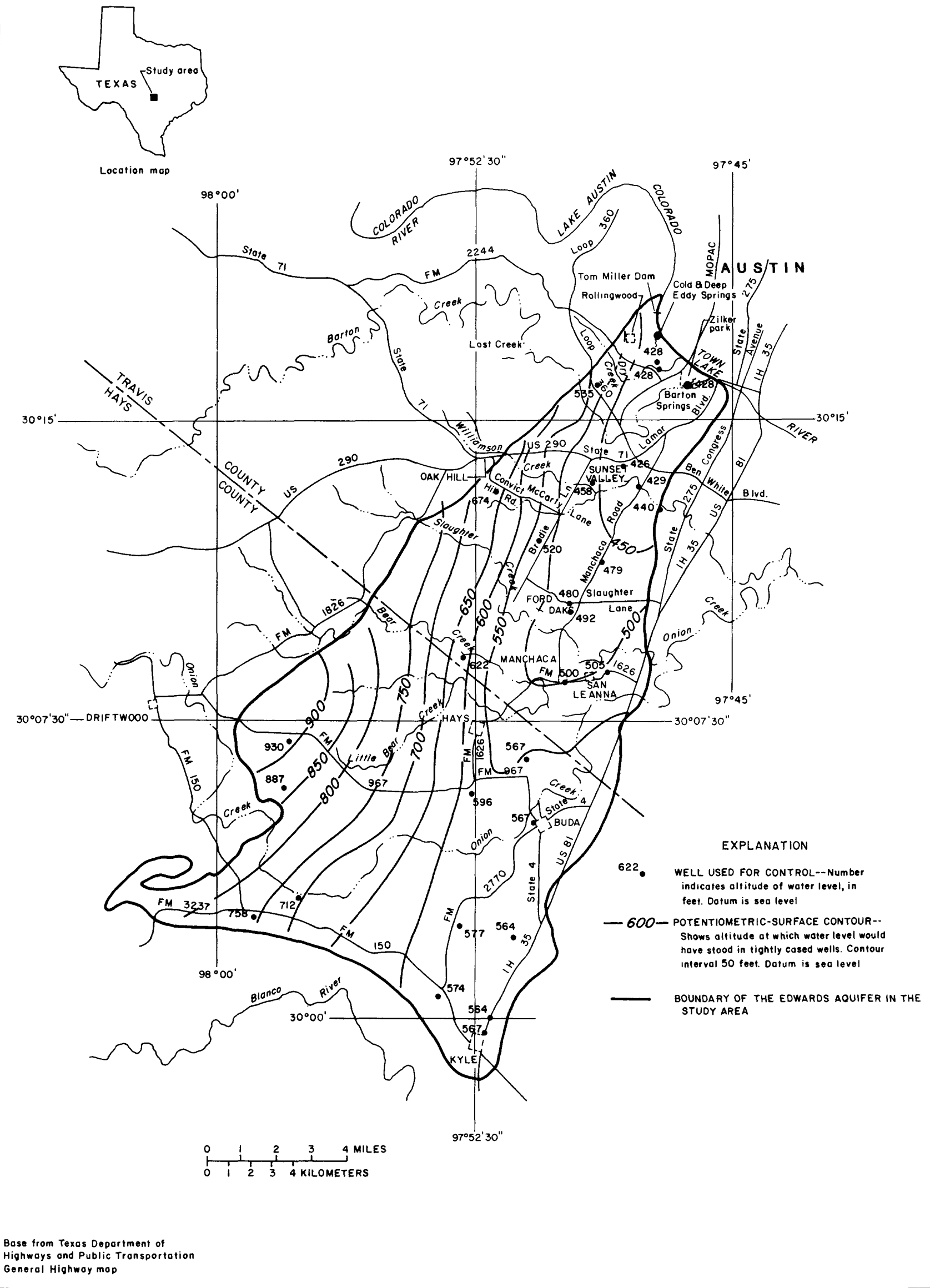

Figure 17.--Potentiometric surface of the Edwards aquifer during drought of 1956. 


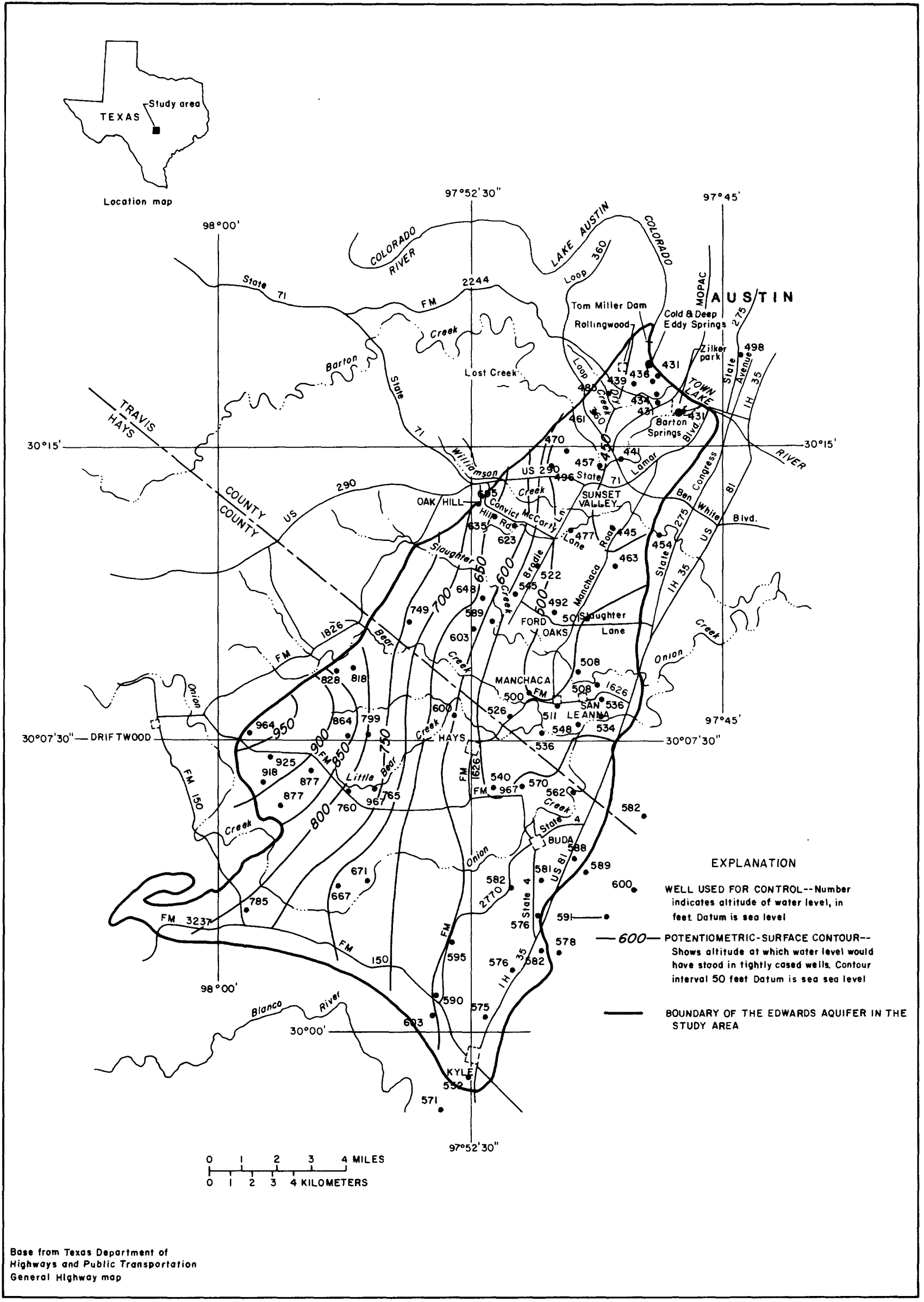

Figure 18.--Potentiometric surface of the Edwards aquifer during low-fiow conditions for Barton Springs, August 1978. 


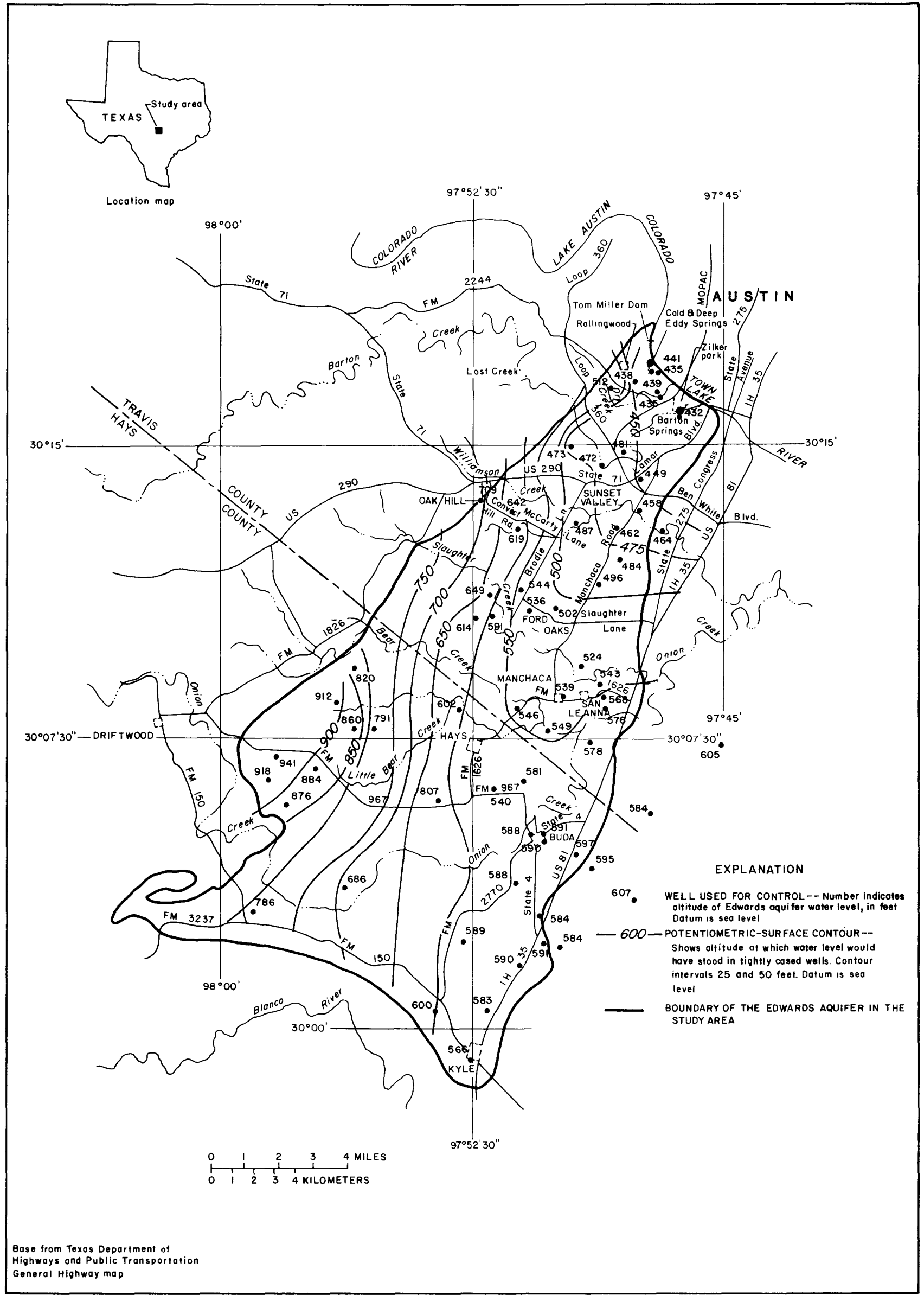

Figure 19.--Potentiometric surface of the Edwards aquifer during average-flow conditions for Barton Springs, January 1981. 


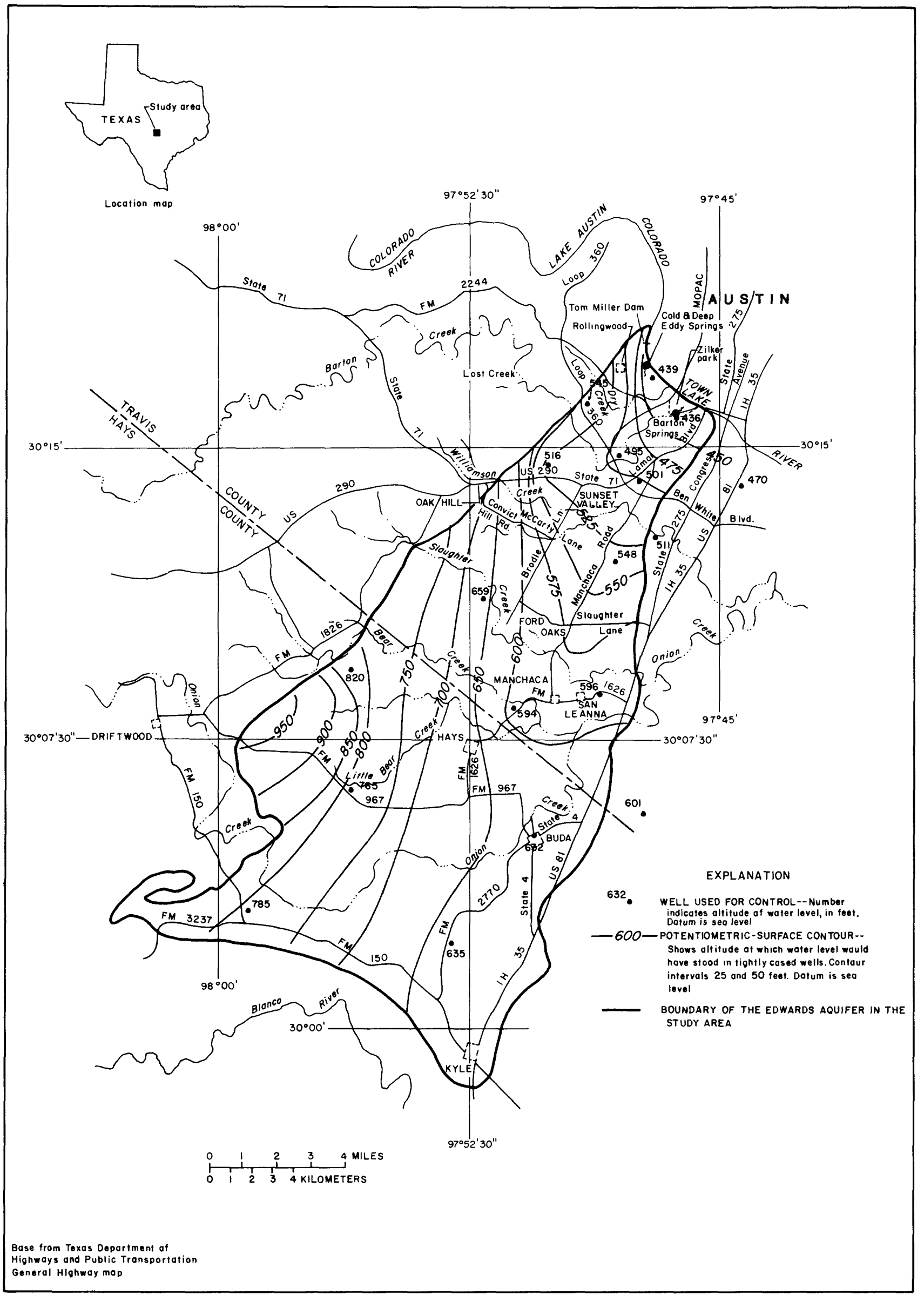

Figure 20.--Potentiometric surface of the Edwards aquifer during high-flow conditions for Barton Springs, June 1979. 
Water-level measurements for wells in the Rollingwood area (fig. 2), when compared with the fluctuations of water levels in the Barton Springs area, indicate that these areas are hydraulically independent. This was determined by reviewing changes in ground-water levels caused by fluctuating surface-water stages at a dam dounstream from Barton Springs. This dam creates a water surface that is about $8 \mathrm{ft}$ higher than the main-spring elevation. This dam al so creates "back-water" that affects ground-water al titudes proximate to Barton Springs. Periodically, the pool level is lowered about $4 \mathrm{ft}$ so that cleaning and maintenance can be performed in the pool.

Water levels in wells YD-58-42-903, YD-58-42-915, and YD-58-50-216 consistently show declines of varying magnitudes each time the pool is lowered (fig. 21). The water level for well YD-58-42-913, located in the Rollingwood area about $0.5 \mathrm{mi}$ west of the springs, shows no change during the period. Additional water-level measurements in other wells in the Rollingwood area, including YD-58-42-813, YD-58-42-911, and YD-58-42-925, have all consistently shown no effect from changing the pool levels. All of the Rollingwood area wells that were monitored are between 0.5 and $0.75 \mathrm{mi}$ west of Barton Springs. Water levels in wells that were monitored south of Barton Springs, including YD-58-50-216 located $2.5 \mathrm{mi}$ south of the springs, consistently display effects from the pool being lowered. The location of the wells proximate to Barton Springs is shown in figure 22.

Senger (1983) identified a difference in chemical quality between Barton Springs and wells in the Rollingwood area wich further suggests the lack of hydraulic connection between this area and Barton Springs. He also noted that water levels in wells in the Rollingwood area showed no correlation with the discharge of Barton Springs, even though water levels in wells south of Barton Springs do correlate well with flow of Barton Springs. The fault traces in this area are shown in figure 22. These faults probably create barriers to ground-water flow moving to the east, so that water movement in the Rollingwood area cannot discharge to Barton Springs. Ground-water flow in the area probably moves along the fault traces to discharge at Cold and Deep Eddy Springs (fig. 22).

Runoff flowing across the recharge area recharges the aquifer along fractures and other openings that cross the creeks. The water reaches the water table very quickly as indicated by water levels in wells close to creeks in the recharge area. Figure 23 shows water levels for Barton Creek at Loop 360 and for well YD-58-50-217, about $500 \mathrm{ft}$ south of the creek (fig. 22), during and after the storm of June 23, 1982. The water level in the well began rising within 1 hour after the water level began to rise in the creek. The bottom of this well is about $75 \mathrm{ft} l$ lower than the channel of Barton Creek near the well. The water level in the aquifer is often below the bottom of the well at the mell site, and has been as high as $8 \mathrm{ft}$ below the creek channel, a range of at least $67 \mathrm{ft}$.

Water-level changes for well YD-58-50-216 after the storm of 0ctober 6 , 1981, are shown in figure 24. The location of this well is shown in figure 22. Geophysical logs show that the water level in this well is al ways below the top of the Edwards aquifer, thus the well is clearly in the unconfined area. As shown at the top of figure 24, the water level began rising within an hour of the beginning of precipitation. Even though the well is not near a creek, water levels in this well and in the other four wells which had water-level 


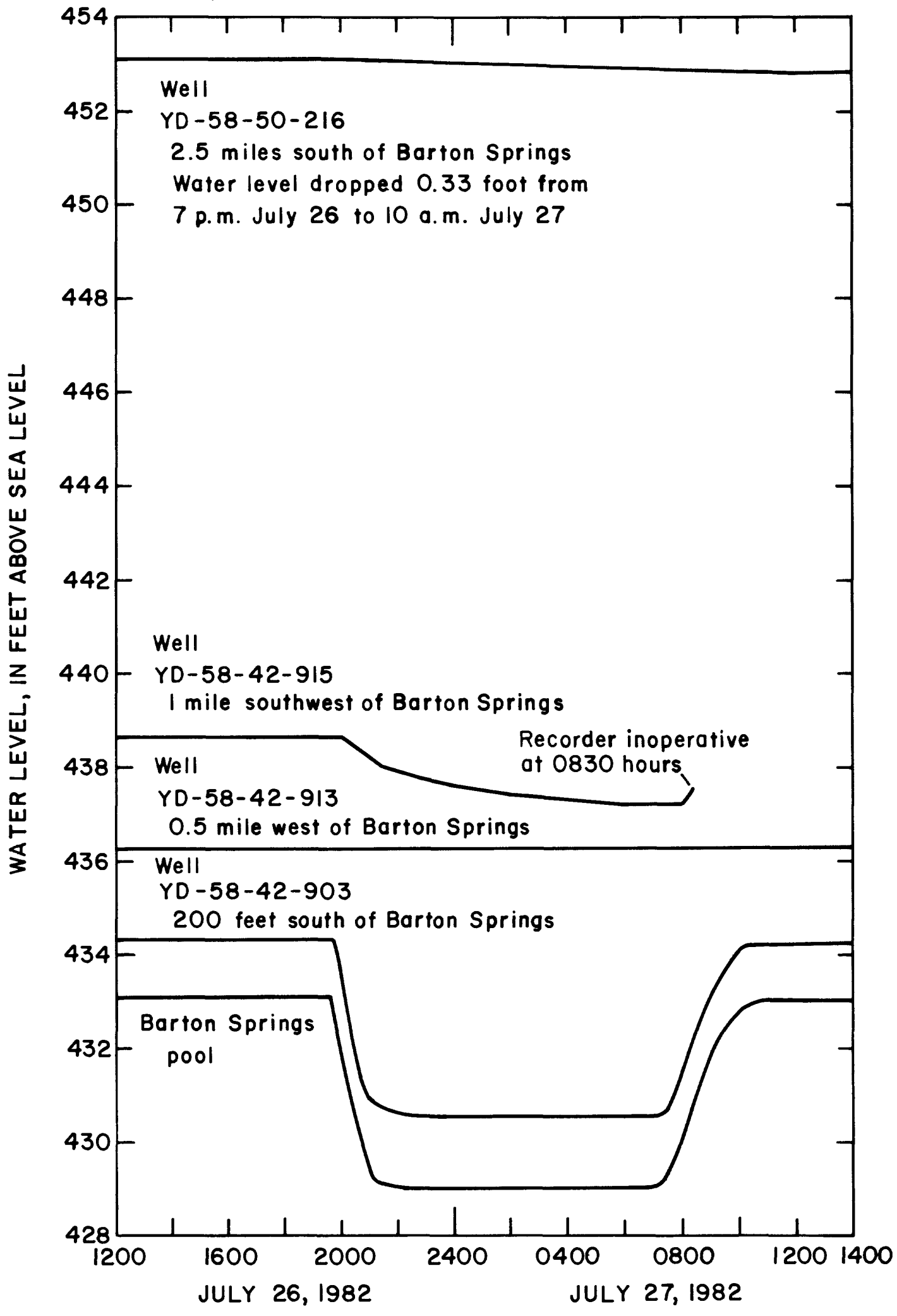

Figure 21.--Hydrographs for Barton Springs pool and four nearby wells for July 26-27, 1982. 


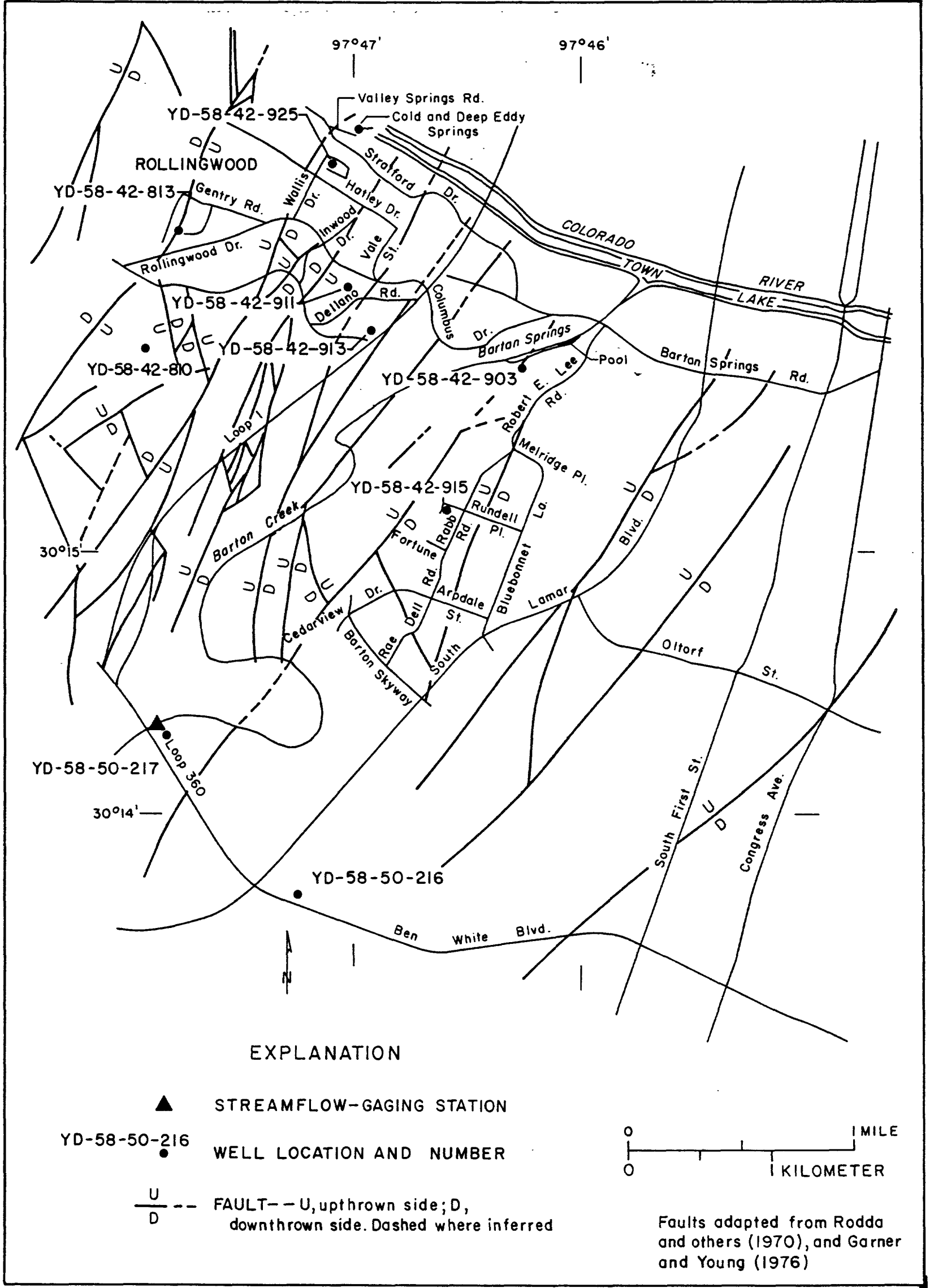

Figure 22.--Location of wells used to monitor the effects of changing the water level in Barton Springs pool. 


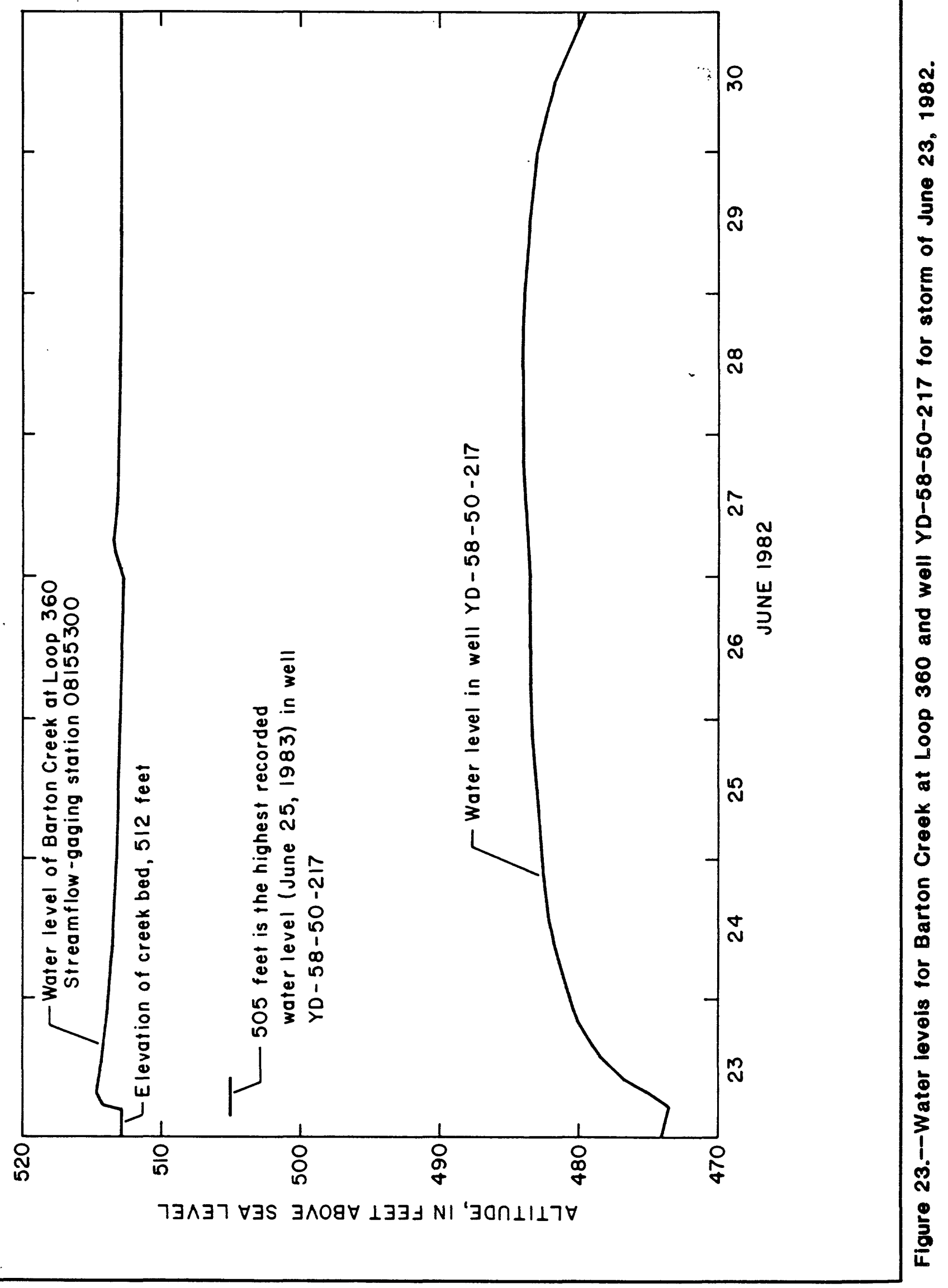



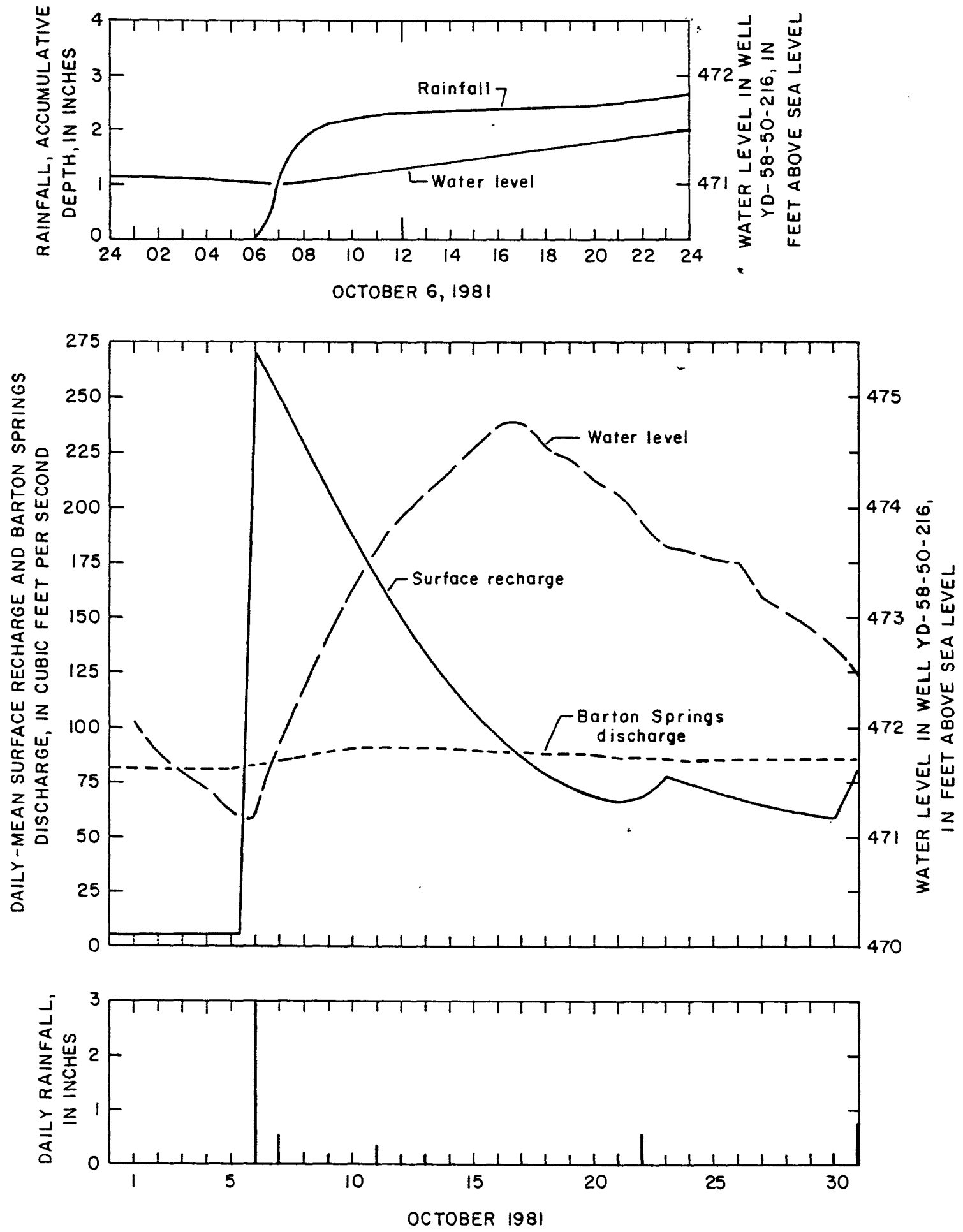

Figure 24.--Precipitation, surface recharge, Barton Springs discharge, and water-level changes for well YD-58-50-216 during high-recharge period of October 1981. 
recorders rise very quickly after precipitation occurs. The discharge at Barton Springs also begins to increase on the same day that substantial precipitation occurs (see figs. 29 to 31 ).

The hydraulic interconnection within the aquifer is also demonstrated in figure 24. As illustrated, the water level in the well peaked on 0ctober 17 , the same day that surface recharge to the aquifer and the discharge at Barton Springs were about equal. This phenomenon occurred for all five wells with recorders for all large storms recorded. Generally, water levels throughout the aquifer continue to $r$ ise as long as surface recharge exceeds discharge from the aquifer. When recharge drops to a rate that is equal to the discharge, storage and water levels are at their maximum for that period, and the discharge at Barton Springs is at a peak. When the recharge rate is less than discharge, water levels in the aquifer decline and the amount of water in storage, as well as discharge at Barton Springs, decreases. Because this is a karst-type aquifer system, the water moves primarily through cavities. Even though most of the aquifer is considered to be unconfined (fig. 14), water levels change rapidly and are highly correlated through much of the aquifer; a characteristic indicative of a confined aquifer. This occurs probably because much of the water moving through the aquifer is pressurized in the cavities that transport the water.

Water movement within the aquifer is believed to be greatly dispersed. This was demonstrated by a ground-water velocity experiment using dye-tracing procedures near Barton Springs. A small amount of a traceable dye was injected into well YD-58-42-903 ( $\mathrm{fig} .22$ ), about $200 \mathrm{ft}$ from the main spring of Barton Springs. The well is not cased, and the dye was released at the level of a large cavity. Samples taken from the well showed that the dye left the bore shortly after injection. The first detectable part of the dye was discharged from the springs about 10 minutes after the injection. About 1 hour after injection, the maximum concentration of dye was discharging from the springs. The dye concentration decreased slowly after that time, but 8 hours later a detectable concentration of dye was still being discharged from the springs. This test indicates that much dispersion occurs in the aquifer between the well and the springs, a characteristic that probably is inherent throughout much of the aquifer.

\section{Aquifer Storage

Specific Yield

When water levels in the Edwards aquifer are at "average" altitudes, about 18 million acre-ft of the aquifer in the 155-mi 2 study area is water-saturated. Average water levels are considered to occur when Barton Springs is flowing at its long-term mean discharge. Of this volume, about 12 million acre-ft is above the 435-ft altitude of Barton Springs. Specific yield for the water-table part of the aquifer was calculated by computing discharge originating from storage for three separate periods when surface recharge was very low. During each of these periods, discharge from Barton Springs dropped from 69 to $37 \mathrm{ft}^{3} / \mathrm{s}$, and the total discharge from storage was about 10,000 acre-ft for each period. The periods were each about 4 months long. This discharge represents flow from Barton Springs and pumpage volumes. Water-level declines in 40 wells and the physical dimensions of the aquifer were used to determine the volume of aquifer that was dewatered--about 590,000 acre-ft--during each period. It is 
assumed that virtually all the discharge during each of these periods came from the unconfined part of the aquifer. The volume of water that came from the confined area during each of these periods was estimated to be less than 20 acre-ft. This was estimated by using: (1) the average decline of about 16 $\mathrm{ft}$ in potentiometric levels within the confined area during these periods; and (2) the sturage coefficient of $6 \times 10^{-5}$ from the "Storage Coefficient" section of this report. It is evident that almost all the outflow from storage was from the unconfined area.

A mean specific yield of 0.017 for the unconfined part of the aquifer was derived by dividing the volume of outflow from storage $(10,000$ acre-ft) by the volume of lewatered aquifer $(590,000$ acre-ft). A mean specific-yield valut of 0.014 was determined from a transient-state simulation model of the study area (S1ade and others, 1985). The specific yields determined by the model ranged from 0.008 in the western part of the study area, to about 0.06 near Barton Springs. Using 0.017 as the specific yield for the entire aquifer, about 306,000 acre-ft of water is stored within the aquifer, of wich about 204,000 acre-ft is stored above the 435-ft altitude of Barton Springs. This specific yield, however, is based on data from only about 3 percent of the 18 million acre-ft of total saturated aquifer and may not be representative of the entire aquifer.

As shown in figures 15 and 16, water levels throughout much of the aquifer correlate well with discharges at Barton Springs, thus storage conditions may be related to discharges at the springs. The relationship between the discharge at Barton Springs and the total volume of water-saturated aquifer is shown in figure 25. Also shown is the relationship between the discharge of Barton Springs and the volume of water stored, based on the assumption that the specific yield of 0.017 is representative for the entire aquifer. The storage between "high" and "low" water-level conditions is considered "transient" storrage and represents the storage wich discharges at Barton Springs.

As figure 25 shows, the difference in aquifer storage when Barton Springs is discharging $10 \mathrm{ft}^{3} / \mathrm{s}$, the minimum observed flow since 1894, and when Barton Springs is discharging $110 \mathrm{ft}^{3} \mathrm{~s}$, which is exceeded less than 2 percent of the time, is about 31,000 acre-ft. This volume represents only 15 percent of the total storage volume above the altitude of Barton Springs. The remaining 85 percent is presumably available to discharge Barton Springs at rates of less than $10 \mathrm{ft}^{3} / \mathrm{s}$. The transient storage al so represents oniy about 10 percent of the total storage volume, and indicates that most water stored in the aguifer is not available to discharge Barton Springs at rates greater than $10 \mathrm{ft} 3 / \mathrm{s}$.

\section{Storage Coefficient}

In the confined area of the Edwards aquifer (fig. 14), the water derived from storage comes from expansion of the water and compression of the framework of the aquifer. The storage coefficient for the confined zone can be computed from the equation given by Jacob (1950):

$$
S=a b c(d+e / b)
$$

Where: $\quad a=$ specific weight of water $\left(62.4 \mathrm{lb} / \mathrm{ft}^{3}\right)$,

$$
b=\text { porosity of the aquifer (dimensionless), }
$$



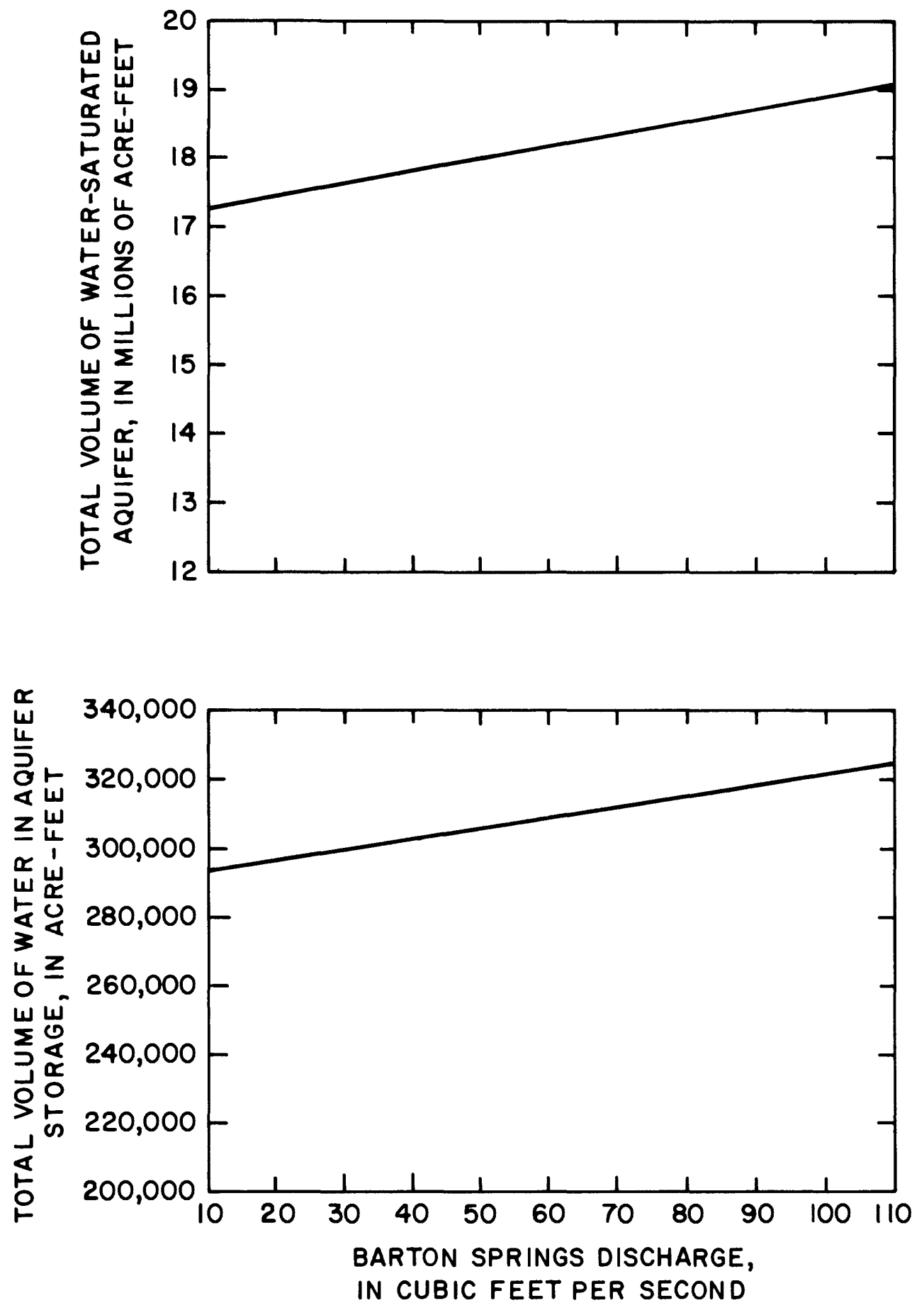

Figure 25.--Relationship between Barton Springs discharge and aquifer storage. 


$$
\begin{aligned}
& c=\text { thickness of the aquifer }(\mathrm{ft}), \\
& d=\text { compressibility of } \\
& e=\text { compressibility of the limestone aquifer skeleton }\left(\mathrm{ft}^{2} / 1 \mathrm{~b}\right) \text {. }
\end{aligned}
$$

The confined-area porosity of the aquifer varies enormously--the larger values of porosity being associated with the larger values of storage coefficients. The lower limit of porosity is 0.017 , wich is the calculated mean specific yield for the unconfined area. The highest specific-yield value determined by Slade and others (1985) is about 0.06--which may be the upper limit of porosity. The thickness of the confined area varies from about 400 to $450 \mathrm{ft}$ ( fig. 7); an average thickness of $430 \mathrm{ft}$ was assumed. Maclay and Small (1984) used an aquifer compressibility value of $6.95 \times 10^{-10} \mathrm{ft}^{2} / 1 \mathrm{~b}$ for the Edwards aquifer south of the study area, and this value is assumed to apply in the study area. The storage coefficient will vary from place to place in the study area depending mainly upon the porosity and the thickness of the aquifer at any one place, however, the probable range is from about $3 \times 10^{-5}$ to $6 \times 10^{-5}$ based on porosity values ranging from 0.017 to 0.06 .

\section{Recharge}

Recharge to the Edwards aquifer in the study area occurs primarily as the infiltration of surface runoff into fractures in the Edwards outcrop area, secondarily as the direct infiltration of precipitation falling on the outcrop area, and as subsurface recharge. Surface runoff comes from about $354 \mathrm{mi}^{2}$ in the tersheds of six creeks, of wich about $90 \mathrm{mi}^{2}$ are within the recharge area, and about $264 \mathrm{mi}^{2}$ are within the watersheds upstream from the recharge area. The areal extent of the recharge area, along with quantities of recharge and methods used to compute those quantities, are presented in this section. Subsurface recharge to the aquifer also is discussed in this section.

\section{Surface Recharge}

The surface recharge area is defined as the area where surface water enters the aquifer. The major creeks that cross the surface recharge area and provide most of the recharge to the Edwards aquifer are Barton, Williamson, Slaughter, Bear, Little Bear, and Onion Creeks (fig. 20). Flow in these creeks percolates to the water table by seeping through fractures and other openings in the creek beds (fig. 13).

During steady flow conditions in 1980, 1981, and 1985, flow-loss studies were conducted on five of these creeks in order to identify the upstream and downstream boundaries of the recharge reach and to determine the quantity and location of the flow losses. Flow-loss studies were not conducted on Little Bear Creek because its drainage area is relatively small, contained entirely within the recharge area, and flow occurs only during periods of storm runoff. The amount of recharge occurring between the measuring sites on each creek was determined by calculating the difference in discharge for adjacent sites. Also the "flow-loss reach" was defined for each creek by identifying the reach of each creek in wich flow is being lost to the aquifer. The locations, descriptions, and flow data for these studies, and water-quality analyses for selected sites were presented by Slade and others (1982). Similar flow-loss studies for Barton Creek were conducted in 1970 by Baker and Watson (1974). Location and flow data from the studies are shown in figure 26. 


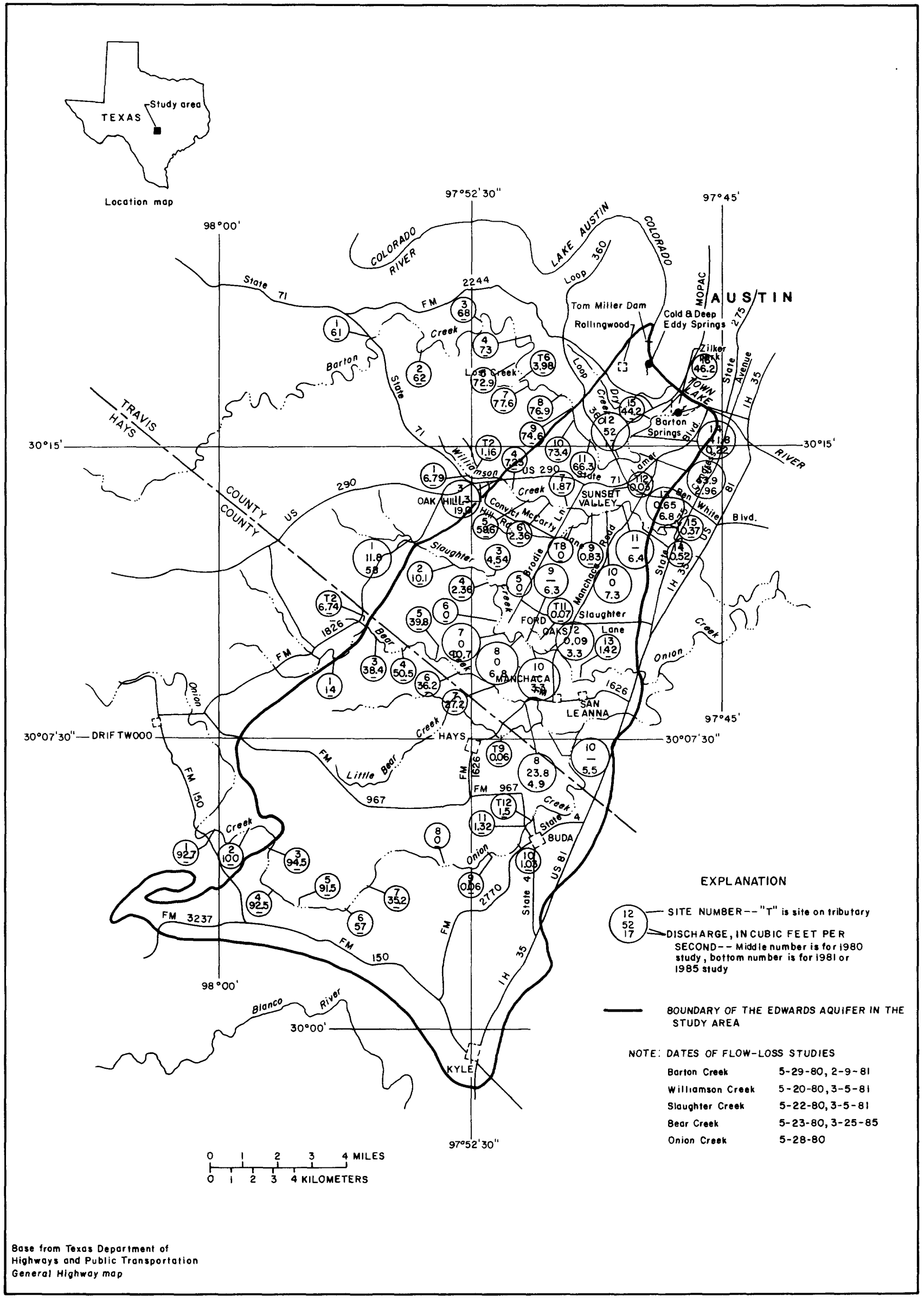

Figure 26.--Streamflow losses in recharge area of the Edwards aquifer. 
The upstream or western boundary of the surface recharge area is defined as the geologic contact between the Edwards aquifer and the Glen Rose Limestone or the Walnut Formation. The downstream boundary of the recharge area was determined from streamflow losses, geologic maps, and field identification of the geologic outcrops in creek beds crossing the recharge area. This boundary is considered as the most easterly of: the easterly extent of the aquifer outcrop, or the boundary of the surface drainages which contribute runoff to the downstream end of the flow-loss reaches of the six major creeks. In Williamson and Slaughter Creeks, the downstream ends of the flow-loss reach coincide with the geologic contact between the Edwards aquifer and the overlying Del Rio Clay. Field identification of the geologic contacts between the Edwards aquifer and overlying formations were used to determine the downstream end of the flow-loss reaches for the other streams in the study area. The recharge area, therefore, includes the drainage area which contributes flow to those reaches, and the outcrop area of the Edwards aquifer. The Edwards aquifer outcrop area was defined by Garner and Young (1976) and De Cook (1963), and the recharge area is shown in figure 27.

Rates and volumes

By July 1979, streamflow-gaging stations were installed at or near the upstream and downstream boundaries of the flow-loss reaches on all six of the major streams that recharge the aquifer, so that the volume of surface recharge could be determined. Water-quality samples were collected at 9 of these sites so that the quality of recharge waters can be evaluated, and 13 recording rain gages were installed in the watersheds to provide precipitation data for the storms associated with high-recharge conditions. The locations of these gaging sites are shown in figure 28.

The method of estimating surface recharge to the Edwards aquifer is presented by Garza (1962). Recharge consists of the infiltration of streamflow plus direct infiltration of runoff in the interstream areas. The approach of estimating recharge in each stream basin is a water-balance equation, in which recharge within a stream basin is the difference between gaged streamflow upstream and downstream from the recharge area plus the estimated runoff in the intervening area. The intervening area is the drainage area within the recharge area between the two streamflow-gaging stations in each stream basin. Runoff from that area is estimated on the basis of unit runoff from the area upstream from the recharge area.

Hydrographs showing typical daily variations in surface recharge to the aquifer and discharge from Barton Springs are presented in figures 29-31. These hydrographs include August 1979-January 1980, February-July 1980, and October 1981-September 1982, respectively. Al so shown are daily values of precipitation based on mean values from all 13 rain gages in the area. The recharge hydrographs are based on calculated daily-mean values of surface recharge for selected days and estimated recession rates between the calculated days. Figure 29 shows how quickly the discharge of Barton Springs can recede. The 6month period shown was very dry; surface recharge accounted for only about 20 percent of the springflow and the remaining 80 percent came from aquifer storage. Figure 30 shows a very wet period. Several large storms produced large volumes of recharge during the period. Figure 31 shows surface recharge and discharge from Barton Springs for a year. Most of the surface recharge during the year was produced from only a few storms which is typical of most years. 


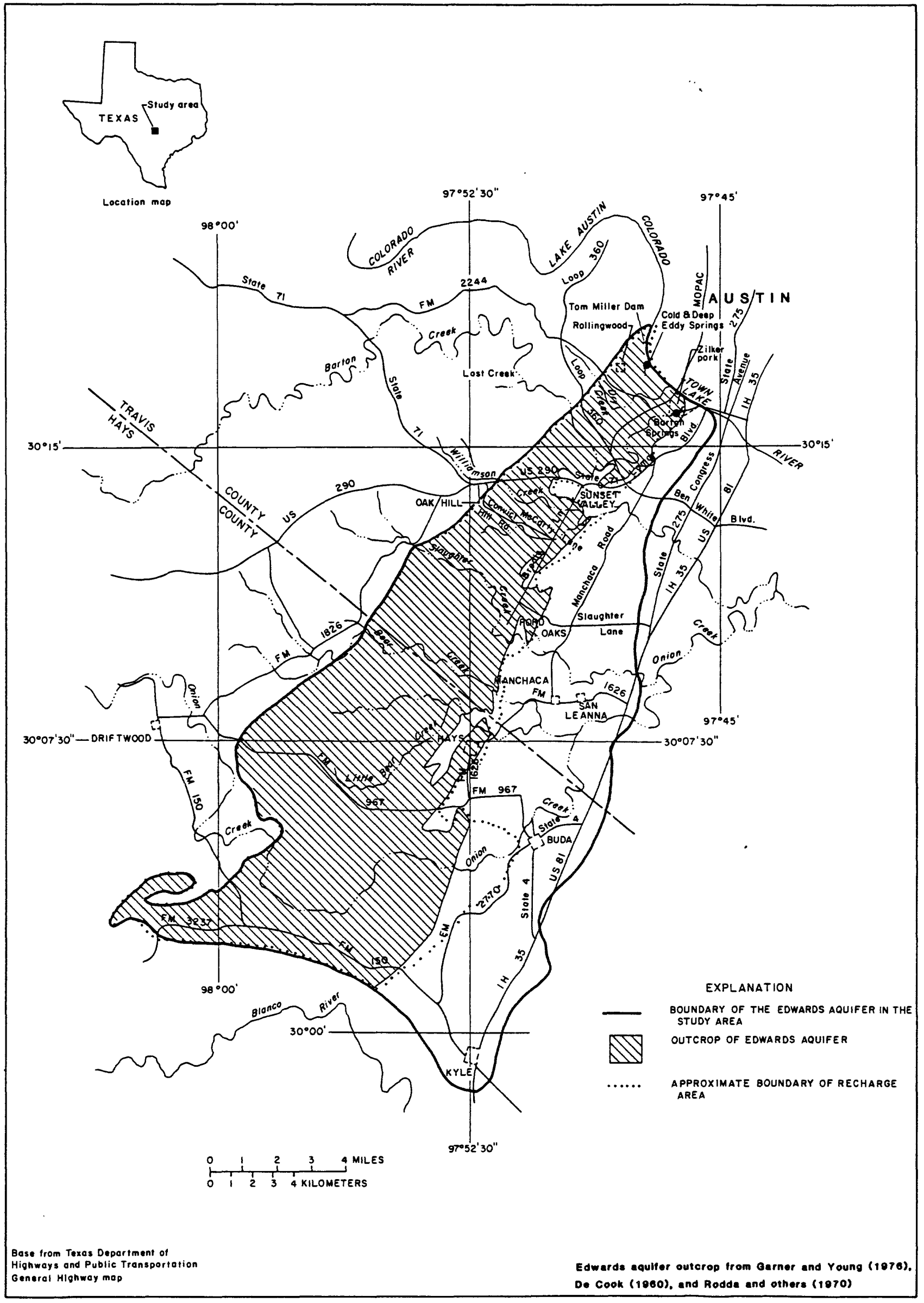

Figure 27.--Surface recharge area for the Edwards aquifer. 


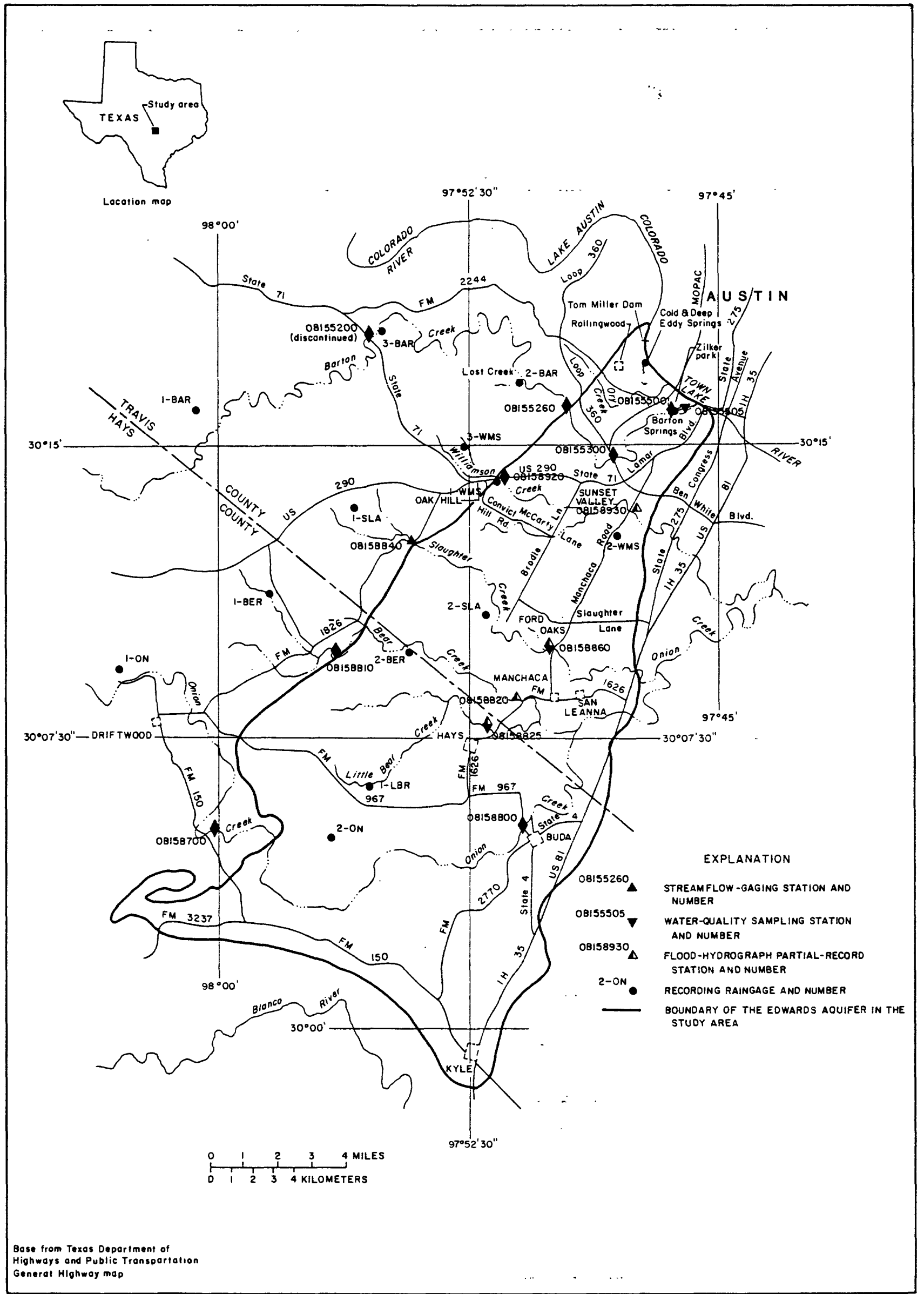

Figure 28.--Location of streamflow-gaging stations, precipitation gages, and surface-water quality sampling sites. 


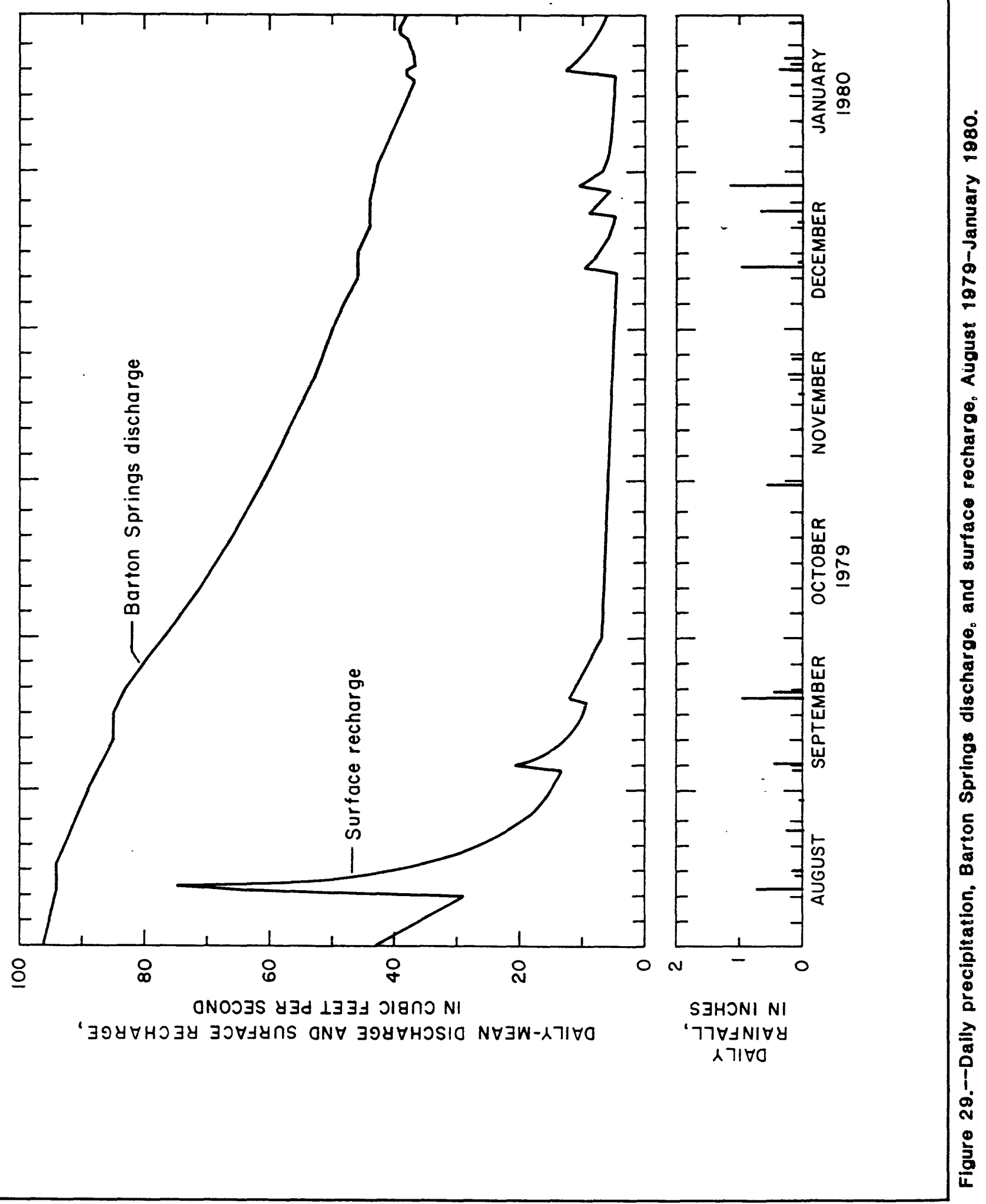




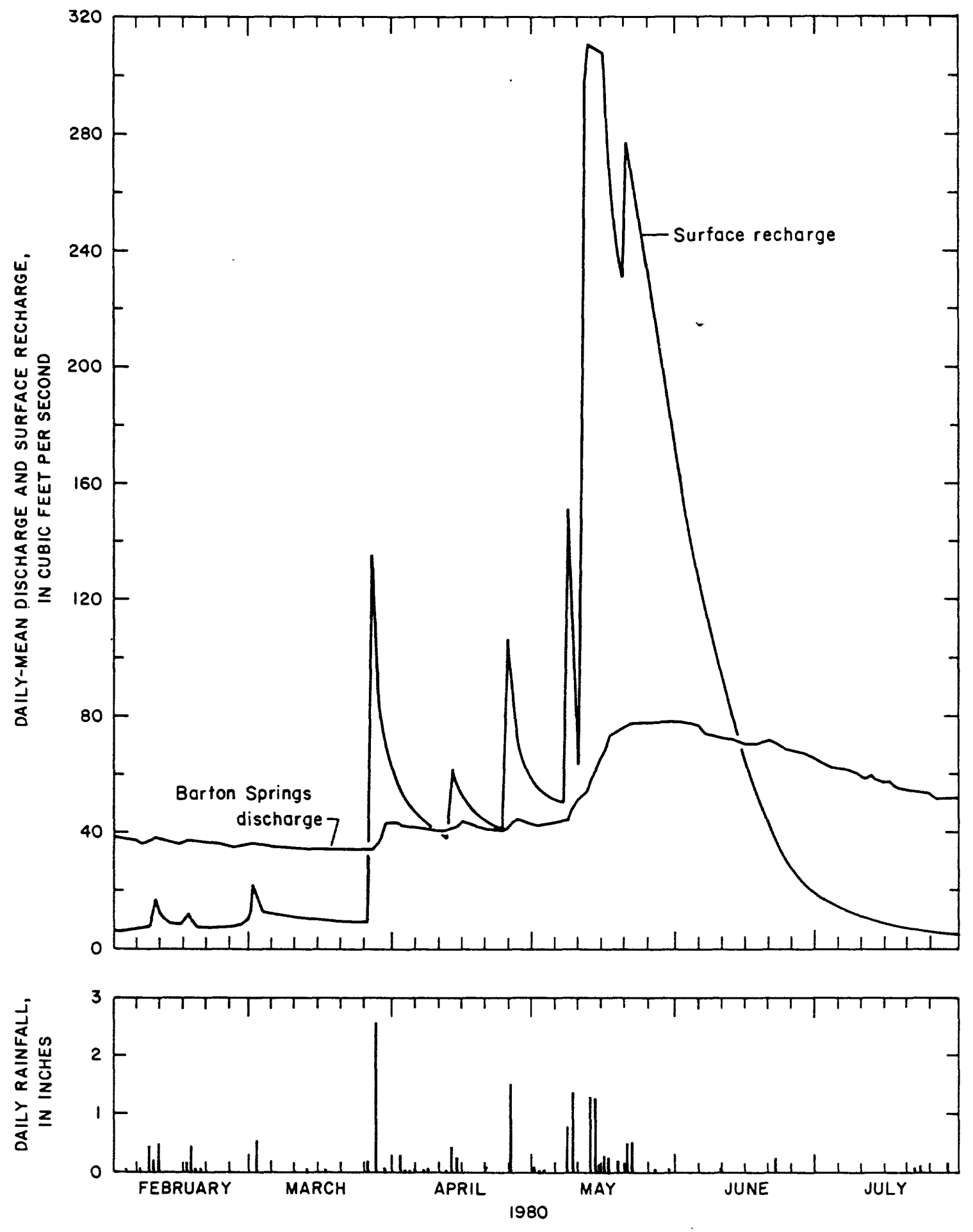

Floure 30.--Daily precipitation, Barton Springs discharge, and surface recharge, February-July 1980. 


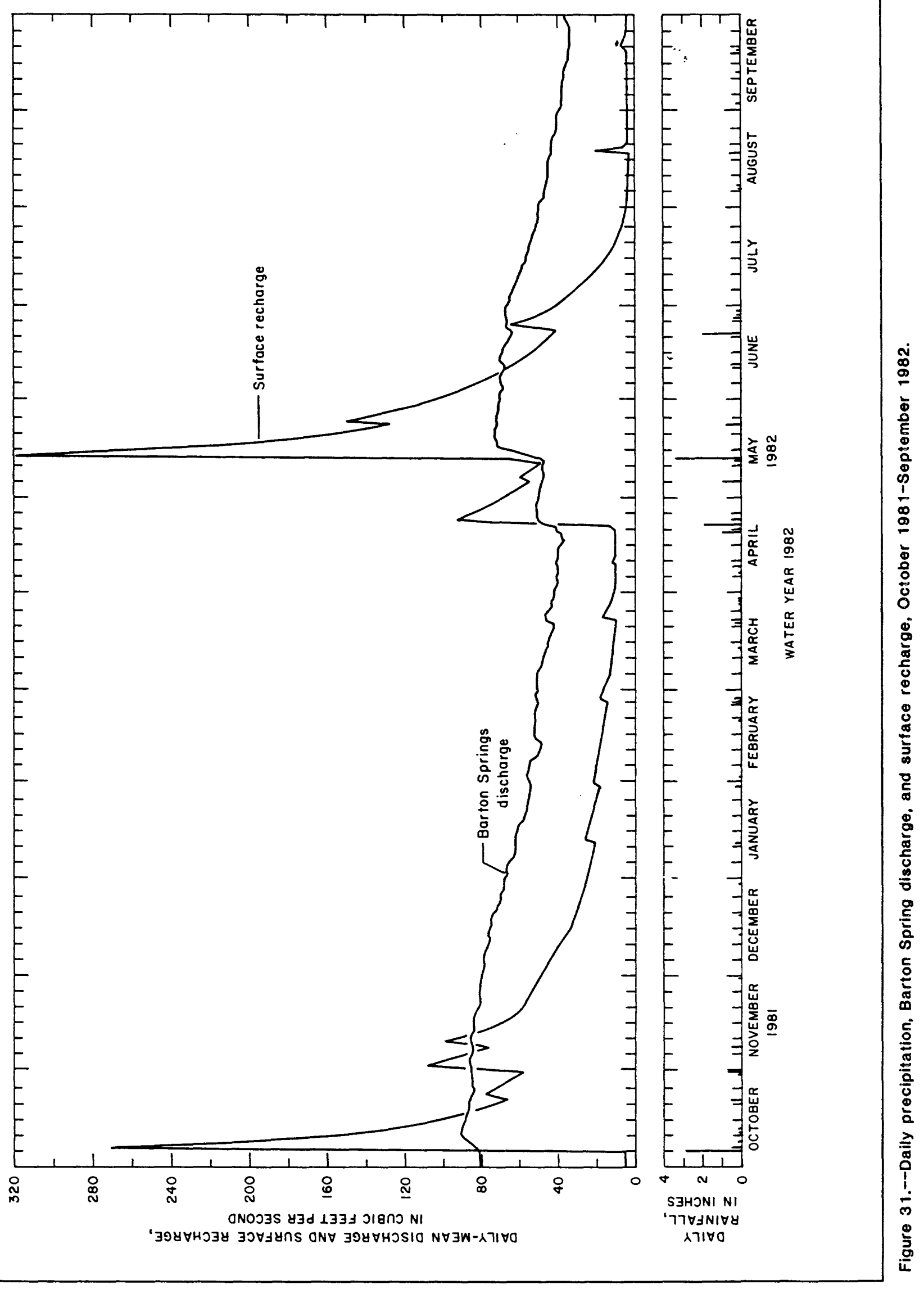


Monthly recharge volumes by watershed were computed for July 1979 to December 1982 and are presented in table 4 along with the total surface recharge and the discharge from Barton Springs. Based on data in this table, the contribution of surface recharge by watersheds is:

\begin{tabular}{lc} 
Watershed & $\begin{array}{c}\text { Percent of } \\
\text { total recharge }\end{array}$ \\
\cline { 2 - 2 } Barton & 28 \\
Williamson & 6 \\
Slaughter & 12 \\
Bear & 10 \\
Little Bear & 10 \\
Onion & 34 \\
\hline
\end{tabular}

Based on data from the streamflow-gaging stations, about 85 percent of the surface recharge: occurs on the main channels of the six creeks. During any given period, recharge from the creeks may vary significantly because of precipitation distributions and drainage basin runoff characteristics.

Each of the major creeks has a maximum infiltration rate that can be transmitted from the creek bed to the water table. The maximum recharge rate was estimated for each creek from the flow-loss studies and from the records of streamflow al the gaging stations. Maximun recharge for Little Bear Creek was estimated frum the Bear Creek value. With the exception of Barton Creek, the water levels in the Edwards aquifer generally are greater than $100 \mathrm{ft}$ below the land surface throughout the recharge area; therefore recharge is not restricted by a lack of storage space in the unsaturated zone. As a result, each creek except Barton Creek has a consistent maximum recharge rate. The recharge occurring at any given time within any of the six creeks will thus be the lesser of the discharge within tlie flow-loss reach or the maximum recharge rate.

Maximum recharge rates for the main channels of the creeks during steddystate flow conditions liave been computed or estimated as follows:

\begin{tabular}{lc}
\hline Creek & $\begin{array}{c}\text { Maximum recharge } \\
\left(\mathrm{ft}^{3} \mathrm{~s}\right)\end{array}$ \\
Barton & 30 to about 70 \\
Williamson & 13 \\
Slaughter & 52 \\
Bear & 33 \\
Little Bear & about 30 \\
Onion & about 120 \\
\hline
\end{tabular}

These rates were determined by comparing discharges at the upstream and downstream ends of the recharge area during times when little or no flow was entering the creek within the recharge area. Maximum recharge ratis during floodflows probably are greater than these values because larger areas of streainbed are directly in contact with faults or other openings to the aquifer. Maximum recharge rates during floods cannot be accurately determined from discharge measurements because the flow is variable, but total maximum surface recharge may be as high as 350 to $400 \mathrm{ft}^{3} / \mathrm{s}$. This value generally will be greater than maximum daily mean-recharge values during storms because the maximum surface recharge rate generally occurs for less than 1 day. All hydrographs in this report present recharge in units of daily-mean values. 
Table 4.---Calculated monthly recharge by watersheds and Barton Springs discharge for the Edwards aquifer, July 1979-December 1982

[acre-ft, acre-foot]

\begin{tabular}{|c|c|c|c|c|c|c|c|c|c|c|}
\hline \multirow[t]{2}{*}{ Year } & \multirow[t]{2}{*}{ Month } & \multicolumn{6}{|c|}{$\begin{array}{l}\text { Monthly recharge by watershed } \\
(\text { acre-ft) }\end{array}$} & \multirow{2}{*}{$\begin{array}{c}\text { Total } \\
\text { surface } \\
\text { recharge } \\
\text { (acre-ft) }\end{array}$} & \multirow{2}{*}{$\begin{array}{l}\text { Barton } \\
\text { Springs } \\
\text { discharge } \\
\text { (acre-ft) }\end{array}$} & \multirow{2}{*}{$\begin{array}{l}\text { Runoff from } \\
\text { recharge } \\
\text { zone } 1 / \\
\text { (acre-ft) } \\
\end{array}$} \\
\hline & & Barton & WitTiamson & STaughter & Bear & $\begin{array}{c}\text { Little } \\
\text { Bear } \\
\end{array}$ & Onion & & & \\
\hline 1979 & $\begin{array}{l}\text { July } \\
\text { Aug. } \\
\text { Sept. } \\
\text { Oct. } \\
\text { Nov. } \\
\text { Dec. }\end{array}$ & $\begin{array}{r}1,020 \\
652 \\
151 \\
41 \\
33 \\
37\end{array}$ & $\begin{array}{r}198 \\
67 \\
99 \\
2 \\
0 \\
30\end{array}$ & $\begin{array}{r}654 \\
304 \\
65 \\
15 \\
2 \\
2\end{array}$ & $\begin{array}{r}496 \\
433 \\
138 \\
90 \\
50 \\
68\end{array}$ & $\begin{array}{r}452 \\
380 \\
120 \\
78 \\
44 \\
59\end{array}$ & $\begin{array}{r}1,190 \\
595 \\
278 \\
231 \\
128 \\
119\end{array}$ & $\begin{array}{r}4,010 \\
2,430 \\
850 \\
460 \\
260 \\
310\end{array}$ & $\begin{array}{l}6,030 \\
5,730 \\
4,980 \\
4,220 \\
3,250 \\
2,800\end{array}$ & $\begin{array}{r}3,370 \\
250 \\
342 \\
13 \\
8 \\
107\end{array}$ \\
\hline \multirow[t]{2}{*}{1980} & $\begin{array}{l}\text { Jan. } \\
\text { Feb. } \\
\text { Mar. } \\
\text { Apr. } \\
\text { May } \\
\text { June }\end{array}$ & $\begin{array}{r}90 \\
114 \\
493 \\
2,000 \\
3,010 \\
1,020\end{array}$ & $\begin{array}{r}10 \\
58 \\
64 \\
246 \\
1,300 \\
641\end{array}$ & $\begin{array}{r}1 \\
12 \\
116 \\
203 \\
3,850 \\
207\end{array}$ & $\begin{array}{r}50 \\
80 \\
229 \\
296 \\
1,080 \\
526\end{array}$ & $\begin{array}{r}44 \\
70 \\
196 \\
258 \\
1,710 \\
461\end{array}$ & $\begin{array}{r}151 \\
184 \\
271 \\
765 \\
3,170 \\
2,510\end{array}$ & $\begin{array}{r}350 \\
520 \\
1,370 \\
3,770 \\
14,120 \\
5,370\end{array}$ & $\begin{array}{l}2,370 \\
2,110 \\
2,170 \\
2,490 \\
3,850 \\
4,230\end{array}$ & $\begin{array}{r}52 \\
137 \\
600 \\
481 \\
13,650 \\
372\end{array}$ \\
\hline & $\begin{array}{l}\text { July } \\
\text { Aug. } \\
\text { Sept. } \\
\text { Oct. } \\
\text { Nov. } \\
\text { Dec. }\end{array}$ & $\begin{array}{r}54 \\
8 \\
309 \\
1,710 \\
1,510 \\
3,260\end{array}$ & $\begin{array}{r}0 \\
0 \\
119 \\
27 \\
20 \\
80\end{array}$ & $\begin{array}{r}12 \\
0 \\
48 \\
52 \\
96 \\
399\end{array}$ & $\begin{array}{r}56 \\
8 \\
236 \\
613 \\
233 \\
585\end{array}$ & $\begin{array}{r}50 \\
7 \\
242 \\
536 \\
204 \\
512\end{array}$ & $\begin{array}{r}190 \\
79 \\
912 \\
1,940 \\
1,370 \\
2,730\end{array}$ & $\begin{array}{r}360 \\
100 \\
1,870 \\
4,880 \\
3,430 \\
7,570\end{array}$ & $\begin{array}{l}3,490 \\
2,560 \\
2,200 \\
2,840 \\
2,580 \\
3,060\end{array}$ & $\begin{array}{r}4 \\
17 \\
522 \\
1,900 \\
328 \\
932\end{array}$ \\
\hline \multirow[t]{2}{*}{1981} & $\begin{array}{l}\text { Jan. } \\
\text { Feb. } \\
\text { Mar. } \\
\text { Apr. } \\
\text { May } \\
\text { June }\end{array}$ & $\begin{array}{l}1,800 \\
1,150 \\
4,460 \\
1,330 \\
793 \\
1,390\end{array}$ & $\begin{array}{r}45 \\
240 \\
1,500 \\
258 \\
1,220 \\
1,980\end{array}$ & $\begin{array}{r}313 \\
362 \\
2,010 \\
339 \\
425 \\
3,970\end{array}$ & $\begin{array}{r}366 \\
611 \\
1,540 \\
683 \\
460 \\
2,580\end{array}$ & $\begin{array}{r}320 \\
535 \\
1,780 \\
597 \\
402 \\
2,580\end{array}$ & $\begin{array}{l}2,070 \\
2,390 \\
3,570 \\
3,170 \\
1,960 \\
3,470\end{array}$ & $\begin{array}{r}4,910 \\
5,290 \\
14,860 \\
6,380 \\
5,260 \\
15,970\end{array}$ & $\begin{array}{l}2,980 \\
2,930 \\
4,070 \\
3,780 \\
3,540 \\
4,830\end{array}$ & $\begin{array}{r}633 \\
1,170 \\
14,680 \\
1,660 \\
7,260 \\
145,480\end{array}$ \\
\hline & $\begin{array}{l}\text { July } \\
\text { Aug. } \\
\text { Sept. } \\
\text { Oct. } \\
\text { Nov. } \\
\text { Dec. }\end{array}$ & $\begin{array}{r}1,190 \\
710 \\
220 \\
2,830 \\
1,650 \\
832\end{array}$ & $\begin{array}{r}503 \\
10 \\
40 \\
40 \\
10 \\
\quad .5\end{array}$ & $\begin{array}{r}546 \\
36 \\
23 \\
208 \\
341 \\
129\end{array}$ & $\begin{array}{l}883 \\
201 \\
178 \\
484 \\
244 \\
148\end{array}$ & $\begin{array}{l}773 \\
176 \\
156 \\
422 \\
212 \\
130\end{array}$ & $\begin{array}{r}3,570 \\
957 \\
794 \\
2,580 \\
2,000 \\
1,110\end{array}$ & $\begin{array}{l}7,470 \\
2,090 \\
1,410 \\
6,560 \\
4,460 \\
2,350\end{array}$ & $\begin{array}{l}6,270 \\
5,770 \\
5,110 \\
5,270 \\
4,960 \\
4,580\end{array}$ & $\begin{array}{r}7,430 \\
110 \\
50 \\
6,140 \\
74 \\
0\end{array}$ \\
\hline \multirow[t]{2}{*}{1982} & $\begin{array}{l}\text { Jan. } \\
\text { Feb. } \\
\text { Mar. } \\
\text { Apr. } \\
\text { May } \\
\text { June }\end{array}$ & $\begin{array}{r}504 \\
241 \\
262 \\
855 \\
3,370 \\
2,020\end{array}$ & $\begin{array}{r}.1 \\
20^{.1} \\
347 \\
400 \\
40\end{array}$ & $\begin{array}{r}75 \\
43 \\
39 \\
339 \\
2,370 \\
538\end{array}$ & $\begin{array}{r}99 \\
56 \\
50 \\
124 \\
1,010 \\
460\end{array}$ & $\begin{array}{r}87 \\
49 \\
44 \\
109 \\
1,080 \\
486\end{array}$ & $\begin{array}{r}698 \\
480 \\
368 \\
579 \\
2,780 \\
1,680\end{array}$ & $\begin{array}{r}1,460 \\
870 \\
780 \\
2,350 \\
11,010 \\
5,220\end{array}$ & $\begin{array}{l}3,700 \\
2,910 \\
2,830 \\
2,560 \\
3,790 \\
4,050\end{array}$ & $\begin{array}{r}73 \\
53 \\
52 \\
387 \\
23,940 \\
1,410\end{array}$ \\
\hline & $\begin{array}{l}\text { July } \\
\text { Aug. } \\
\text { Sept. } \\
\text { Oct. } \\
\text { Nov. } \\
\text { Dec. }\end{array}$ & $\begin{array}{r}319 \\
44 \\
6 \\
5 \\
6 \\
11\end{array}$ & $\begin{array}{c}0 \\
50 \\
2 \\
{ }_{64}^{6} .1 \\
60\end{array}$ & $\begin{array}{r}63 \\
.9 \\
.2 \\
0 \\
1 \\
25\end{array}$ & $\begin{array}{r}151 \\
19 \\
3 \\
15 \\
110 \\
98\end{array}$ & $\begin{array}{r}132 \\
17 \\
3 \\
13 \\
97 \\
85\end{array}$ & $\begin{array}{r}533 \\
104 \\
127 \\
82 \\
141 \\
208\end{array}$ & $\begin{array}{r}1,200 \\
230 \\
140 \\
120 \\
420 \\
490\end{array}$ & $\begin{array}{l}3,480 \\
2,690 \\
2,140 \\
2,030 \\
2,020 \\
2,520\end{array}$ & $\begin{array}{l}0^{.3} \\
4 \\
0 \\
0 \\
0\end{array}$ \\
\hline \multicolumn{2}{|c|}{ Total } & 41,510 & 9,790 & 18,230 & 15,840 & 15,710 & 52,230 & 153,310 & 149,770 & 233,690 \\
\hline
\end{tabular}

1/ Total runoff occurring at the streamflow-gaging stations located at or near the downstream end of the recharge area. 
The maximum recharge rate for Barton Creek varies from 30 to about 70 $\mathrm{ft}^{3} / \mathrm{s}$ during steady-state flow conditions depending upon the ground-water levels under the creek bed. When ground-water levels are low, the saturated zone is below the altitude of the Barton Creek streambed throughout the recharge area, and the maximum recharge that can occur is about $70 \mathrm{ft}^{3} / \mathrm{s}$. When the ground-water levels ar: extremely high, the top of the saturated zone is above the botton of the creek bed for a long reach of the creek upstream from Barton Springs, and thus, that reach will reject recharge. During periods of high ground-water levels, many intermittent springs in the creek bed will flow, and only about $30 \mathrm{ft}^{3} / \mathrm{s}$ can be recharged from Barton Creek. During the May 29, 1980, flow-loss study for Barton Creek, ground-water levels were high. As shown in figure 26 , the flow of Barton Creek increased from $41.8 \mathrm{ft}^{3} / \mathrm{s}$ at site 14 to $46.2 \mathrm{ft}^{3} / \mathrm{s}$ at site 16 , an increase of $4.4 \mathrm{ft}^{3} / \mathrm{s}$. No local runoff was occurring at the time, and the increase in flow was due to the discharge froin intermittently flowing springs in the creek bed within this reach. During the February 9, 1981, flow-loss investigations, ground-water levels were low and the streamflow decreased through that same reach. During much of the year, the ground-water levels will be between the low and extreme high conditions mentioned above, and the maximum recharge rate will be between 30 and $70 \mathrm{ft}^{3} / \mathrm{s}$.

A water-budget analysis was done for the total inflow and outflow to the surface drea wich contributes recharge to the aquifer by using the precipitation, streamflow, and surface recharge data (Woodruff, 1984). This analysis was done so that the portion of precipitation which contributes to recharge and runoff from the recharge area could be put in perspective. The area (354 $\mathrm{mi}^{2}$ ) includes the recharge area $\left(90 \mathrm{mi}^{2}\right)$ and the drainage area which contributes runoff to the recharge area $(264 \mathrm{mi} 2)$. The period of record used for the analysis was July 1979 through December 1982. Inflow to the area is composed of precipitation, which was determined from 13 rain gages in the area (fig. 28). Outflow from the area is composed of recharge to the aquifer (table 4), runoff from the area (table 4), and evapotranspiration. Withdrawals of the surface water in the area are probably minimal and thus not considered in the computation. Storage change in the soil is al so minimal because of the quantities of the wher constituents.

Inflow values are known, as are two of the three components of outflow, thus the water-budget equation was expressed as:

$$
\text { Evapotranspiration = Precipitation - Recharge - Runoff, }
$$

so that evapotranspiration could be calculated. During the 42-month accounting period, the total mean precipitation over the area was 136 in., which averaged about 39 in. per year. This is about 7 in. or 22 percent nigher than the annual long-term mean precipitation for Austin. However, the mean surface recharge during the period was $60 \mathrm{ft}^{3} / \mathrm{s}$, or 20 percent higher than the long-terim mean surface recharge. Because precipitation was higher than normal, runoff was probably higher during the period. The calculated evapotranspiration, while lased on prec ipitation higher than normal, is reduced by recharge and runoff liigher than normal and thus may be representative of long-terin conditions.

The precipitation during the period contributed about $2,580,000$ acre-ft to the area. Surface recharge and runoff were about 153,300 and 233,700 dcre-ft respectively, thus evapotranspiration calculates to be $2,193,000$ acre- $\mathrm{ft}$. The monthly mean evapotranspiration is 52,201$)$ acre-ft, or 0.23 acre-ft per acre 
over the entire area. This value is within 8 percent of the rate of 0.25 acre-ft per acre per month as reported from field tests of evapotranspiration in the Edwards aquifer in the San Antonio area (Rugen and others, 1977 ). Evapotranspiration, recharge, and runoff respectively compose 85,6 , and 9 percent of total precipitation.

\section{Potential recharge enhancement}

The Edwards Underground Water District implemented a recharge-enchancement program in Medina County west of San Antonio that also may be applicable to some degree in the Austin area. Between 1974 and 1982, the Edwards Underground Water District constructed four dams on four small creeks within the Medina River watershed, located within the Edwards aquifer recharge area about $75 \mathrm{mi}$ southwest of the study area. These four dams were designed to store runoff and allow the stored water to recharge the aquifer through sinkholes underlying the reservoirs. Annual recharge to the Edwards aquifer for three of the reservoirs are summarized in the following table (Edwards Underground Water District, written commun., 1983):

\begin{tabular}{lcc}
\hline Reservoir site & Year constructed & $\begin{array}{c}\text { Mean-annual recharge } \\
\text { (acre-ft) }\end{array}$ \\
\hline Parker Creek & 1974 & 691 \\
Middle Verde Creek & 1978 & 917 \\
San Geronimo Creek & 1979 & 758 \\
\hline
\end{tabular}

Records are not yet available for the fourth reservoir, which was completed on Seco Creek in 1982.

There probably are no sinkholes in the Edwards aquifer within the study area that have the infiltration capacity of the four Medina County sites. However, the six streams in the study area have flow-loss reaches that would function as recharge sites in a similar manner as the sinkholes in Medina County.

Under present (1985) unregulated conditions, storm runoff that exceeds the maximum recharge rate for an individual creek flows beyond the recharge area. In contrast, during low-flow conditions, the total flow in the six creeks is less than the maximum recharge rate, and all of the flow is recharged to the Edwards aquifer in the flow-loss reaches of the creeks. In order to salvage the storm runoff that is not recharged to the aquifer, it would be possible for State or local agencies to construct dams upstream from the flowloss reaches that would impound the storm runoff as was done by the Edwards Underground Water District in Medina County. The stored runoff then could be slowly released to the flow-loss reaches so that all the runoff would recharge the Edwards aquifer within the flow-loss reaches. Because the complete elimination of streamflow in the dounstream reaches of the creeks may be unacceptable for a variety of reasons, it may be possible to regulate release of the stored storm runoff so that both significantly increased recharge to the aquifer and some minimum streamflow in the creeks can be achieved.

Data from Williamson Creek can be used to illustrate the flow regime in the six creeks under present unregulated conditions. On March 5, 1981, 19.0 $\mathrm{ft}^{3} / \mathrm{s}$ was flowing near the upstream boundary of the recharge area, and 6.4 
$\mathrm{ft}^{3} / \mathrm{s}$ was flowing at the dounstream boundary (fig. 26). Thus, about $13 \mathrm{ft}^{3} / \mathrm{s}$, whic $h$ is the maximum recharge rate for the fluw-loss reach of Williamson Creek, was recharging the aquifer. In contrast, on May $20,1980,11.3 \mathrm{ft}^{3} / \mathrm{s}$ was flowing at the upstream boundary and discharge decreased dounstream until there was no flow in the channel at site 10 , which is within the recharge area (fig. 26). Because the discharge of $11.3 \mathrm{ft}^{3} / \mathrm{s}$ was less than the maximum recharge rate of $13 \mathrm{ft}^{3} / \mathrm{s}$ for the entire flow-loss rtach of Williamson Creek, all the streamflow recharged the aquifer within the flow-loss reach.

As figures 29-31 show, daily-mean surface recharge varied from about 5 to about $320 \mathrm{ft}^{3} / \mathrm{s}$ for the periods represented and increased rapidly after precipitation began in the area. The flow-loss studies indicate that recharge rates of the six creeks are fairly uniform within the flow-loss reach of an individual creek. This results in a fairly uniform volume of recharge per mile of losing reach.

The recharge hydrographs (figs. 29-31) show that maximum surface recharge occurs for only short periods following heavy precipitation. This condition exists less than 10 percent of the time; thus, over 90 percent of the time certain reaches of the creeks within the recharge area are dry. For most years, about three to seven storms produce runoff that exceeds the maximum recharge rate. About one-half of the time or more, total recharge is less than 20 $\mathrm{ft}^{3} / \mathrm{s}$, and this amount occurs in the upstrean part of the recharge ared within an area that represents less than one-fourth of the total recharge area. Thus for about one-half of the time, more than three-fourths of the recharge area is not receiving recharge.

The large storns that produce much of the recharge generally produce much more runoff than can be recharged. Figure 32 presents an example of surface recharge and total runoff from the recharge area during a large storm. As this figure shows, much more runoff is produced by large storms than is recharged to to the aquifer. Runoff measured at gaging stations located at or near the downstream end of the recharge area, along with monthly recharge, is presented in table 4. The runoff from the recharge area represents that part of the total runoff that exceeded the maximum recharge rate and, thus, did not recharge the aquifer. From July 1979 to December 1982 the excess runoff was about 234,000 acre-ft, and the total surface recharge was dbout 153,000 acre-ft.

Most of the runoff leaving the recharge area is contained in two of the six creeks--Barton and Onion Creeks. Of the $354 \mathrm{mi}^{2}$ total drainage area which contributes to recharge, about $120 \mathrm{mi}^{2}$ is within the Barton Creek watershed, and $166 \mathrm{mi}^{2}$ is within the Onion Creek watersiled. About 170,000 of the 234,000 acre-ft of excess runoff whicli occurred froin July 1979 to December 1982 was distributed almost equally between the two creeks. The maximum recharge rate that Barton and Onion creeks can accept is al so higher than that for the other creeks. It is obvious that these two creeks could provide much more potentidi recharge by enhancement than could the other creeks.

Onion Creek is the most southerly Creek in the study area (fig. 28), thus enhanced recharge in this creek would prubably raise ground-water levels between the flow-loss reach on Onion Creek and Barton Springs as that water moved toward the springs, thus providing more water available for pumpage throughout much of the aquifer. Whereas recharge water from Barton Creek moves eastward to Barton Springs, and because very little pumpage occurs along this 


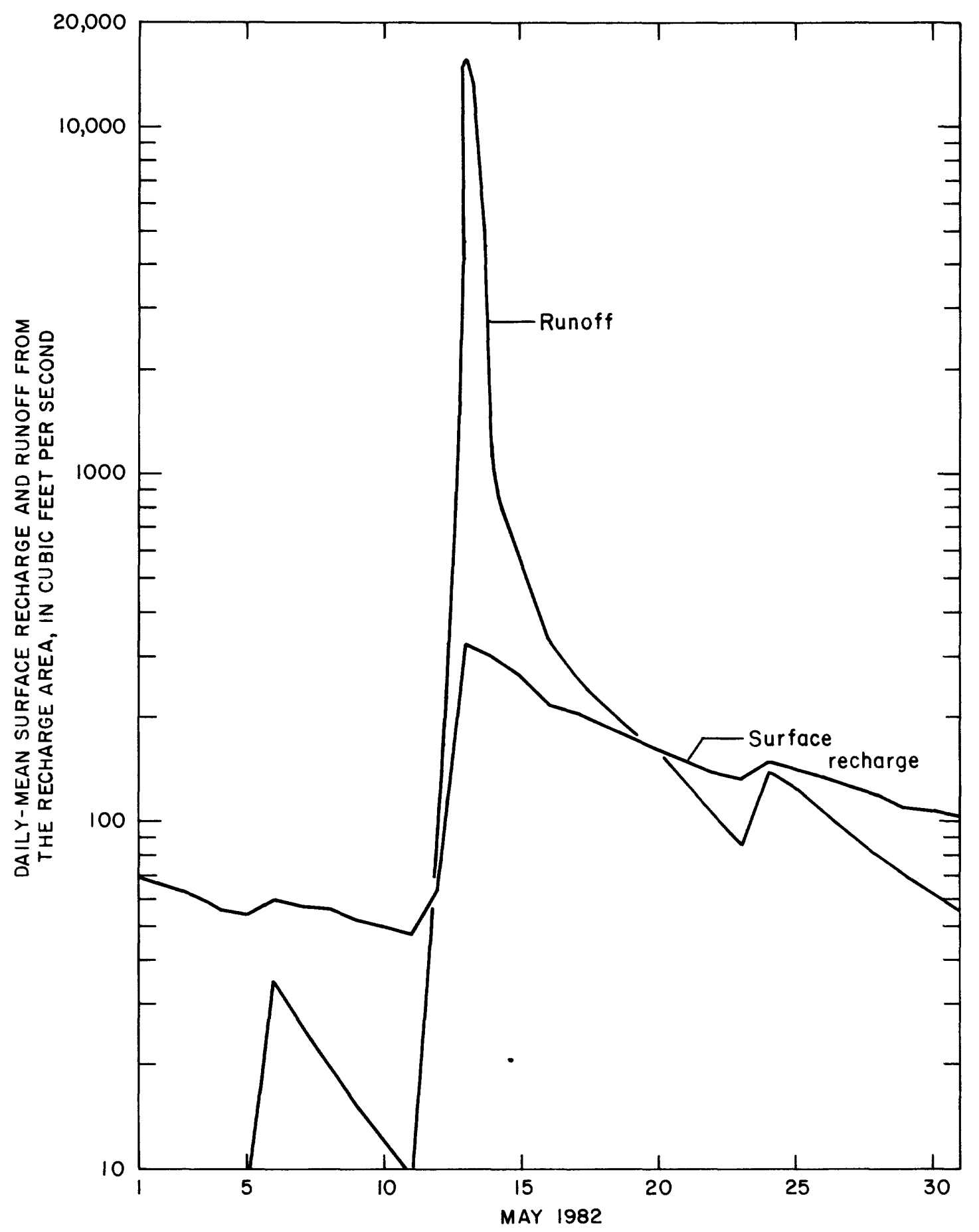

Figure 32.--Daily-mean values of runoff from the recharge area and surface recharge to the aquifer, May 1982. 
creek, most of the enhanced recharge from this creek would probably be discharged at Barton Springs, thus increasing the flow from the springs.

Local governing officials from cities in the study area are studying a proposal to build a large reservoir on Onion Creek near the upstream end of the recharge area. The proposed reservoir would impound more than 40,000 acre-ft of water. Possible uses of the waters that are being studied are recharye enhancement, source of water supply to the area, or botll. During July 1979 to December 1982, about 52,000 acre-ft of recharge to the Ellwards aquifer occurred in Onion Creek (table 4). However, during this time, alınost 88,000 acre-ft of runoff occurred at the downstream end of the recharge area in onion Creek. The proposed reservoir would be large enough to store most of this runoff because of the infrequent nature of the storms producing the runoff. If the outflow were maintained at about $120 \mathrm{ft}^{3} / \mathrm{s}$, the maximum recharge rate for Onion Creek, much of this runoff would recharge the aquifer. If only one-half of this runoff volume were converted to recharge, the total mean surface recharge, and thus Barton Springs discharge, could probably be increased about 30 percent. Some of the effects of this recharge enhancement on the Edwards aquifer and costs and benefits of this reservoir are presented by Ruiz (1985).

\section{Upward leakage}

\section{Subsurface Recharge}

Water levels from wells completed in the Trinity aquifers within and near the study area are presented in figure 33, along with the water levels and the potentiometric surface of the Edwards aquifer in January 1981. The water levels for wells in the Trinity aquifers were taken from George and others (1941), DeCook and Doyel (1955), Arnow (1957), DeCook (1960), Brune and Duffin (1983), and Slade and others (1983). Information concerning the Trinity aquifers is presented in table 2 .

West of the Mount Bonnell fault, which is the westernmost fault of the Balcones fault zone and the western boundary of the Edwards aquifer, the potentiometric surfaces of the upper, middle, and lower Trinity aquifers are significantly different (Brulle and Duffin, 1983). However, as figure 33 shows, the water levels for many wells in the Trinity aquifers are comparable to levels of nearby wells in the Edwards aquifer, thus the possibility of leakage between the aquifers exists. The data are not conclusive, because most of the wells in the Trinity aquifers were measured only once between 1940 and 1981 and, thus, the measurements reflect a large range in hydrologic conditions. There is evidence, however, that water levels in the Edwards and upper Trinity aquifers fluctuate very little.

As stated in the "Ground-Water Flow Systern" section of this report (and as shown in Slade and others, 1985, fig. 4), water levels for wells in the Edwards aquifer have fluctuated only about 2 to $15 \mathrm{ft}$ in the western part of the study area. Most of the wells in the Trinity dquifer are also in the western part of the study area. Five of the 72 wells measured annually by the Geological Survey are developed in the upper Trinity aquifers within the Edwards outcrop area. All of the water levels for each of the five wells are comparable to levels of nearby wells in the Edwards aquifer. The five wells, YD-58-50-409, LR-58-49-803, LR-58-49-805, LR-58-49-806, and LR-58-57-101 (fig. 14) had respective water-level fluctuations of $15,11,12,10$, and $16 \mathrm{ft}$ based on 4 to 7 


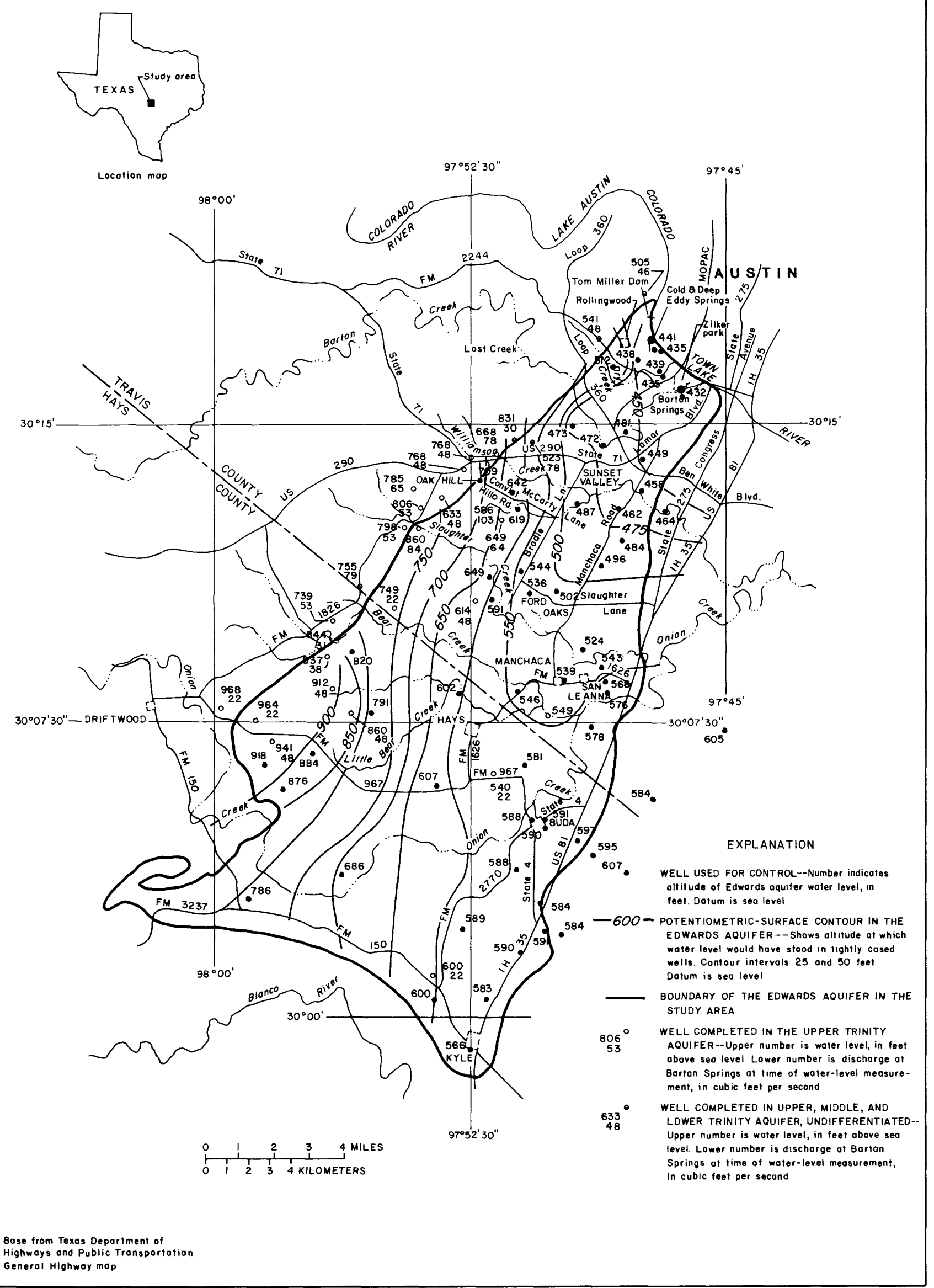

Figure 33.--Ground-water leveis in the Edwards and Trinity aquifers. 
measurements made of these wells from 1978 to 1982 . Extreme "wet" and "dry" conditions exist within the period of the measurments, thus the fluctuations are probably comparable to maximum water-level changes due to hydrologic variations. These water-level fluctuations are comparable to fluctuations of nearby wells in the Edwards aquifer (fig. 14) and indicate that water levels change very little for wells in the upper Trinity aquifer, as in wells of the Edwards aquifer in that area. Because water levels in the Edwards and upper Trinity aquifers are relatively consistent, they probably can be meaningfully compared regardless of hydrologic conditions.

Chemical analyses are available for about 140 wells developed in the Edwards aquifer, and over 100 wells in the Trinity aquifer within and near the study area (DeCook, 1960; Brune and Duffin, 1983; Slade and others, 1981, 1982, 1983, 1984; and Gordon and others, 1985). The results of chemical analyses for major inorganic anions in water from selected wells (fig. 34) are evidence of leakage from the Trinity aquifer to the Edwards aquifer. The anionic composition of solutes in water from well YD-58-50-215 is typical of most wells that penetrate only the Edwards aquifer; about 90 percent of the anions in this water, based on concentrations in milliequivalents per liter, represent alkalinity (predominantly bicarbonate), and about 5 percent is sulfate. The anionic composition of water from most wells that penetrate the upper Trinity aquifer or the middle Trinity aquifer differs significantly from the composition of water in the Edwards aquifer. For example, about 75 percent of the anions in water from well YD-58-49-204, wich penetrates only the upper Trinity aquifer, is alkalinity, and about 15-20 percent is sulfate. Wells YD-58-49-112 and Yo-58-49-221 penetrate both the upper Trinity aquifer and the middle Trinity aquifer. About 30-35 percent of the anions in water from these wells is alkalinity, and about 60-65 percent is sulfate.

The anionic composition of solutes in several wells that penetrate only the Edwards aquifer is atypical of water in the Edwards aquifer. About 60-70 percent of the anions in water from these wells is alkalinity, and about 25-35 percent is sulfate. This composition suggests a mixture of waters from the Edwards and adjacent aquifers and is evidence that leakage to the Edwards aquifer from the upper Trinity aquifer may be occurring.

Thirteen of about 140 wells in the Edwards aquifer suggest leakage from the Trinity aquifers and include:

$$
\begin{aligned}
& \text { YD-58-42-818 } \\
& \text { YD-58-50-405 } \\
& Y D-58-50-407 \\
& Y D-58-50-409 \\
& Y D-58-50-503 \\
& \text { YD-58-50-505 } \\
& \text { YD-58-50-803 }
\end{aligned}
$$

YD-58-50-805
YD-58-50-809
YD-58-50-812
YD-58-50-819
YD-58-58-407
$E-43$

All the wells suggesting leakage are near faults, wich may be the major conveyers of leakage. Natural differences in hydrostatic head are probably responsible for most of the leakage. The Walnut Formation, which lies between the Edwards and upper Trinity aquifers, may have sufficient vertical permeability to allow water movement between the aquifers. Also, vertical displacements along faults wich exceed the thickness of the Walnut Formation would cause the upper Trinity and Edwards aquifers to be in direct contact along those faults. 


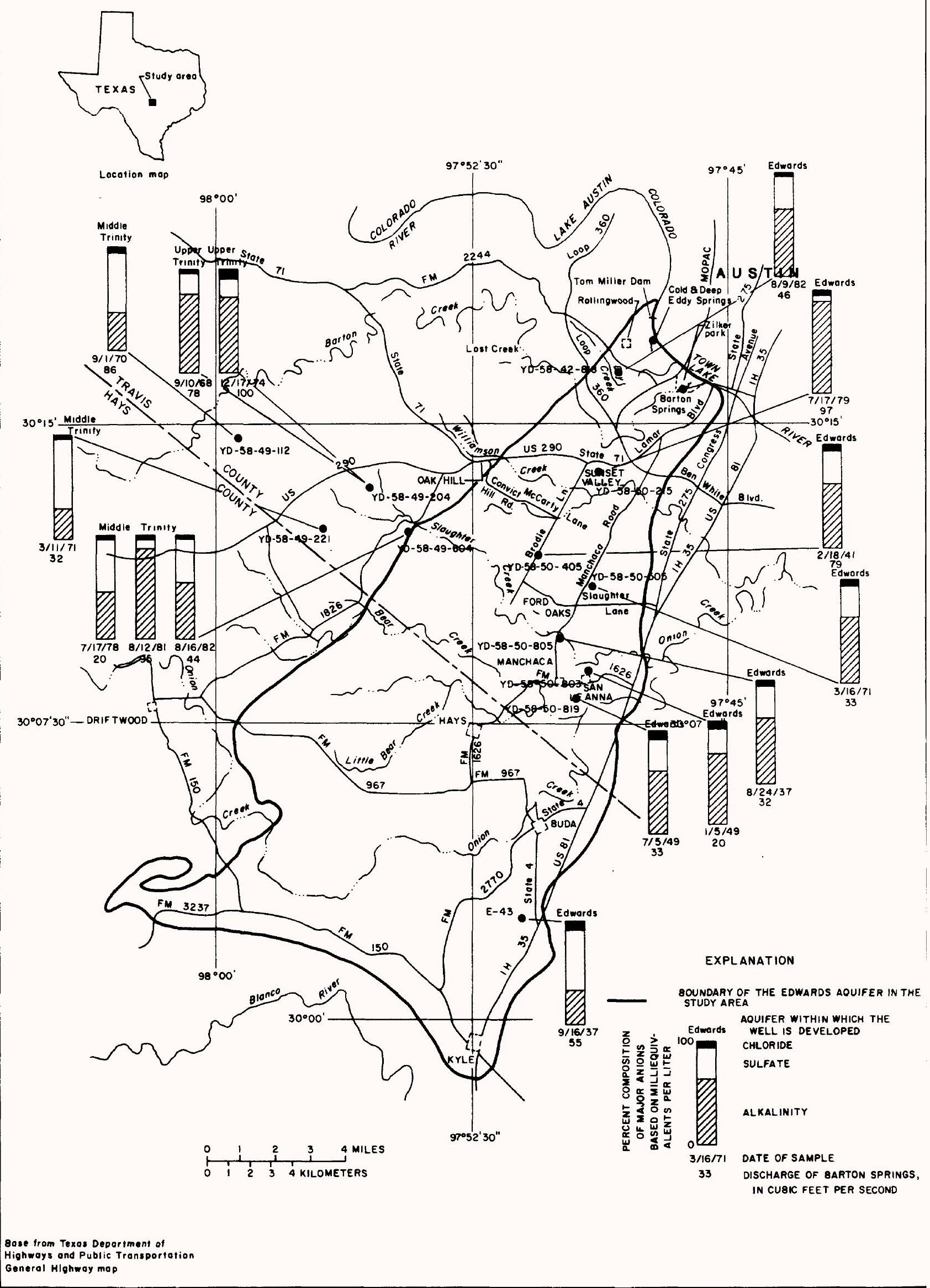

Figure 34.--Inorganic anions for selected wells In the Edwards and underlying aquifers. 
Water movement could then occur directly between those two aquifers. Along the western boundary of the Edwards aquifer at the Mount Bonnell fault, the Edwards and upper Trinity aquifer are in direct contact. Some water movement into the Edwards aquifer probably occurs from the Upper Trinity aquifer to the west. However in some of the areas near faults, the vertical fracture permeability may be much greater than the lateral permeability normal to the faults. In such areas, pumpage from the Edwards aquifer may induce vertical movement of water froin the underlying aquifers or even deliver water from the Trinity aquifer to the surface that may not be in circulation within the Edwards aquifer.

Identifying water from the Edwards or Trinity aquifers based solely on the inajor inorganic anions is not conclusive. The available data show that some wells drilled deep into the Edwards aquifer have sulfate values greater than shallow wells in the Edwards. Many of the deep wells in the Edwarls aquifer also have higher values of fluoride and higher values of dissolved solids, which also is typical of wells in the Trinity aquifer. The deep wells in the Edwards aquifer could contain "older" water in the Edwards aquifer, or" could also contain a mixture of waters from the Edwards and upper Trinity acyifers. Because the two aquifers are of similar carbonate composition (Maclay and Small, 1984, table 1), the inorganic characteristics of their waters would not be expected to be easily distinguished.

The chemical analyses indicate that leakage of water into the Edwards aquifer from adjacent aquifers is confined to local areas. However, the estimated annual pumpage from the Edwards aquifer as of 1982 averaged about 3,800 acre-ft, which is only about 10 percent of the mean-annual recharge to the aquifer. If future development of wells and pumpage is expanded, the areal extent of leakage from adjacent aquifers may greatly increase. Under such circumstances, the chenical character of the water pumped from wells that penetrate the Edwards aquifer and from Barton Springs may be similar to a mixture of waters from the Edwards and Trinity aquifers.

The Edwards aquifer generally produces water containing lower values of dissolved solids and fluoride than the Trinity aquifers. Brune and Duffin (1983, p. 94-97) state that the upper and the middle Trinity aquifers are moderately favorable for ground-water development, with the upper Trinity aquifer generally having the better water quality. In some areas, however, water from buth Trinity aquifers is treated to lower the concentration of dissolved solids prior to usage. If leakage into the Edwards aquifer became significant under future conditions, the resultant quality of water in the Edwards aquift:r may deteriorate and even require treatment.

\section{Lateral flow}

Lateral flow into the Edwards aquifer within the study area consists of bad-water encroachment from the east; intra-aquifer flow from the Edwards aquifer south of the study area at times; and, as discussed in the previous section, possibly from the upper Trinity aquifer west of the Edwards aquifer.

"Bad-water" encroachment.-The potentiometric-surface map in figure 18 indicates the possibility of movement of water from the "bad-water" zone to the freshwater zone in the northeast part of the study area. When ground-water 
levels are 10w, ground-water flow in this area is to the northwest, rather than in a northerly direction during high ground-water levels (fig. 20). Waterquality data for Barton Springs and well YD-58-50-216 near the "bad-water" 1 ine indicate the influx of "bad water" into the aquifer. Table 5 gives selected dissolved-solids concentrations and associated discharges for Barton Springs. Also listed are dissolved-solids concentrations for selected wells near the "bad-water" line. The results of inorganic chemical analyses for the samples listed in table 5 are plotted on a trilinear diagram (fig. 35). The locations of the sites where these samples were collected also are shown in figure 35 .

When the discharge of Barton Springs is 10w, the increased mineralization of the springflow indicates movement of the poorer quality water (fig. 35 and table 5). During low-flow conditions, sodium and chloride concentrations for Barton Springs and wel1 YD-58-50-216 increase to levels higher than those found in wells developed in the upper Trinity aquifer, which indicate the source of the leakage to be the "bad-water" zone rather than leakage from the upper Trinity aquifer. Well YD-58-50-301, in the "bad-water" zone, exhibits bad-water characteristics during both high and low stages of water in the aquifer (fig. 35). All wells in the freshwater area near the "bad-water" line, except YD-58-50-216, display good-quality water consistently during high and low stages in the aquifer. Well YD-58-50-216 contains good-quality water during high stages and bad-quality water during $10 \mathrm{w}$ stages. Three wells (YD-58-50-508 $Y D-58-50-509$, and $Y D-58-50-602)$ in the freshwater area about $2.5 \mathrm{mi}$ south of wel1 YD-58-50-216 contain fresh water during low-flow conditions. It is likely therefore, that flow into the aquifer from the "bad-water" zone is limited to the area north of those three wells.

Major faults lie along the southern half of the "bad-water" boundary. The altitude of the top of the Edwards aquifer and the major faults in the study area are shown in figure 5. Two of the faults that have the greatest displacement are situated along the bad-water line. One of those faults is just east of the city of Kyle, and the other major fault is just north of the city. As figure 5 shows, the displacement along both of these faults is about $200 \mathrm{ft}$. These faults may influence the location of the "bad water" line and block water movement, which would explain why "bad water" may not encroach into the freshwater aquifer in this region. The aquifer is about $450 \mathrm{ft}$ thick in this area (fig. 7). However, because most of the ground-water movement is through distinct lateral zones, displacement of $200 \mathrm{ft}$ of aquifer could juxtapose high and low permeability beds and thus impede the lateral water movement across that fault. If, in the future, increased pumping significantly lowers potentiometric surfaces in this area, the faults may restrict bad-water encroachment into the well fields.

Water-level measurements for wells on either side of the "bad-water" line indicate that water moves between the freshwater and "bad-water" zones along a reach in the northern part of the aquifer. During high-recharge conditions, water levels within the freshwater zone exceed levels within the "bad-water" zone, and thus, water probably moves into the "bad-water" zone from the freshwater zone. During extended low-recharge conditions, water levels in the "bad-water" zone exceed those levels in the freshwater zone to the west, thus, water moves into the freshwater zone from the east. Another possible source for water in the "bad-water" zone, however, is discussed in the following section. 


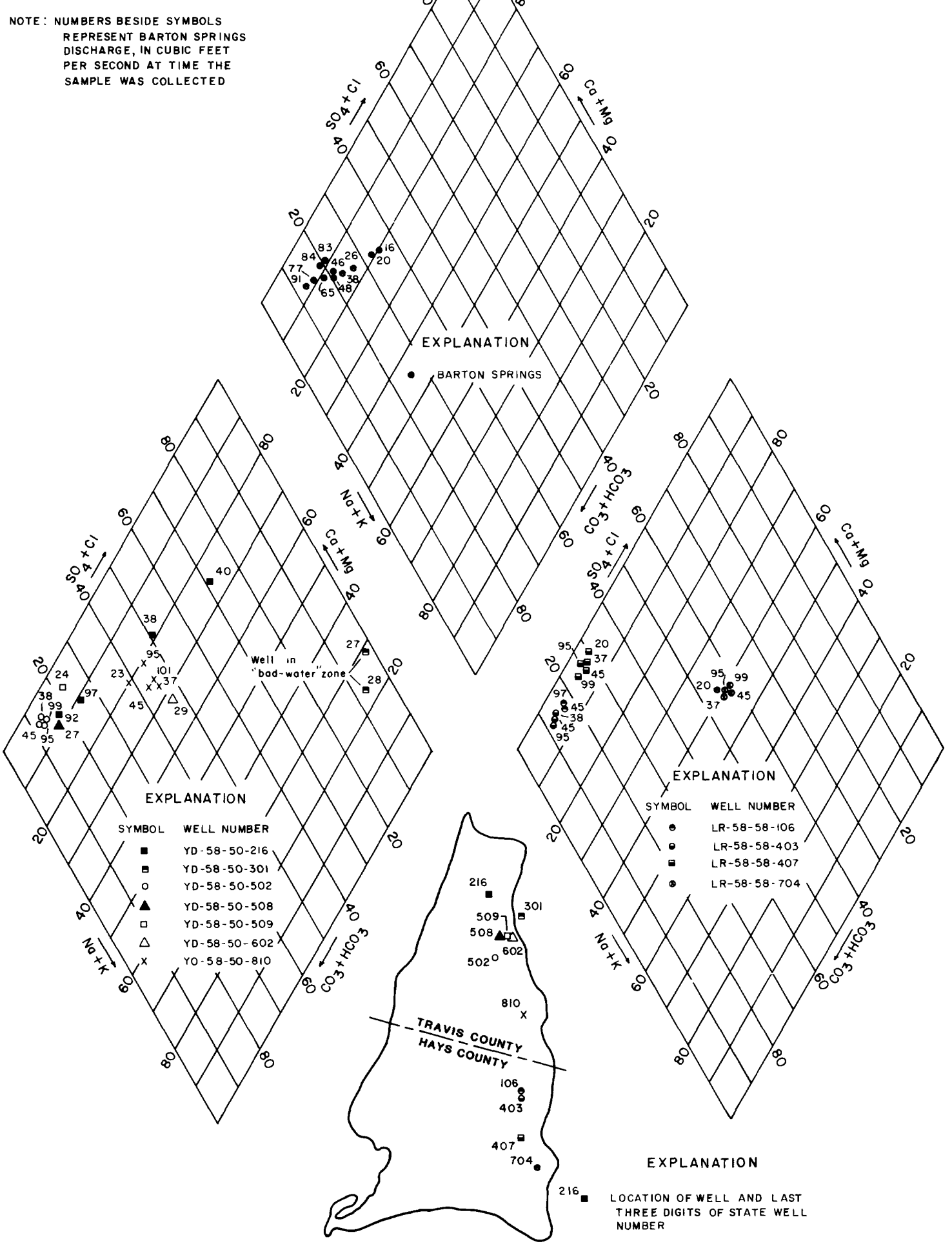

Figure 35.--Trilinear diagrams showing inorganic chemical characteristics of selected samples for Barton Springs and selected wells near the "bad-water" line for various rates of Barton Springs discharge. 
Table 5.--Dissolved-solids concentrations for water-quality samples from Barton Springs and wells near the "bad-water" Tine

[mg/L, milligram per liter; $\mathrm{ft}^{3} / \mathrm{s}$, cubic foot per second]

\begin{tabular}{|c|c|c|c|}
\hline $\begin{array}{c}\text { Site } \\
\text { name/number }\end{array}$ & Sample date & $\begin{array}{c}\text { Dissolved solids } \\
(\mathrm{mg} / \mathrm{L})\end{array}$ & $\begin{array}{r}\text { Barton Springs } \\
\text { discharge }\left(\mathrm{ft}^{3} / \mathrm{s}\right) \underline{1} \\
\end{array}$ \\
\hline Barton Springs & $\begin{array}{r}10-27-39 \\
7-18-78 \\
9-27-78 \\
2-28-79 \\
9-19-79 \\
1-16-80 \\
6-4-80 \\
10-17-80 \\
4-8-81 \\
8-24-81 \\
8-9-82\end{array}$ & $\begin{array}{l}407 \\
414 \\
376 \\
336 \\
345 \\
358 \\
305 \\
330 \\
318 \\
327 \\
346\end{array}$ & $\begin{array}{l}16 \\
20 \\
26 \\
84 \\
83 \\
38 \\
77 \\
48 \\
65 \\
91 \\
46\end{array}$ \\
\hline YO-58-50-216 & $\begin{array}{l}7-18-79 \\
9-8-80 \\
8-19-81 \\
8-30-82\end{array}$ & $\begin{array}{r}267 \\
514 \\
346 \\
1,120\end{array}$ & $\begin{array}{l}97 \\
38 \\
92 \\
40\end{array}$ \\
\hline YD-58-50-301 & $\begin{array}{r}10-26-48 \\
7-20-49\end{array}$ & $\begin{array}{l}8,870 \\
1,470\end{array}$ & $\begin{array}{l}27 \\
28\end{array}$ \\
\hline YD-58-50-502 & $\begin{array}{l}7-11-79 \\
9-8-80 \\
8-11-81 \\
8-10-82\end{array}$ & $\begin{array}{l}324 \\
317 \\
329 \\
319\end{array}$ & $\begin{array}{l}99 \\
38 \\
95 \\
45\end{array}$ \\
\hline YD-58-50-508 & $7-29-49$ & 425 & 27 \\
\hline YD-58-50-509 & $10-20-38$ & 316 & 24 \\
\hline YD-58-50-602 & $5-4-71$ & 531 & 29 \\
\hline YD-58-50-810 & $\begin{array}{l}7-10-78 \\
7-5-79 \\
8-28-80 \\
8-11-81 \\
8-10-82\end{array}$ & $\begin{array}{l}423 \\
450 \\
484 \\
488 \\
455\end{array}$ & $\begin{array}{r}23 \\
101 \\
37 \\
95 \\
45\end{array}$ \\
\hline LR-58-58-106 & $\begin{array}{l}7-18-79 \\
8-11-82\end{array}$ & $\begin{array}{l}318 \\
308\end{array}$ & $\begin{array}{l}97 \\
45\end{array}$ \\
\hline LR-58-58-403 & $\begin{array}{l}8-29-80 \\
8-12-81 \\
8-11-82\end{array}$ & $\begin{array}{l}319 \\
321 \\
296\end{array}$ & $\begin{array}{l}38 \\
95 \\
45\end{array}$ \\
\hline LR-58-58-407 & $\begin{array}{l}7-17-78 \\
7-11-79 \\
9-4-80 \\
8-12-81 \\
8-11-82\end{array}$ & $\begin{array}{l}381 \\
359 \\
380 \\
368 \\
360\end{array}$ & $\begin{array}{l}20 \\
99 \\
37 \\
95 \\
45\end{array}$ \\
\hline LR-58-58-704 & $\begin{array}{l}7-24-78 \\
7-11-79 \\
9-4-80 \\
8-12-81 \\
8-11-82\end{array}$ & $\begin{array}{l}622 \\
615 \\
634 \\
613 \\
616\end{array}$ & $\begin{array}{l}20 \\
99 \\
37 \\
95 \\
45\end{array}$ \\
\hline
\end{tabular}

1/ Barton Springs discharges prior to March 1978 are estimated from periodic discharge measurements. 
Intra-aquifer flow.-Subsurface flow to the Edwards aquifer in the study area may occur as a northerly movement of water from the "bad-water" and freshwater zones of the Edwards aquifer south of the study area. W. F. Guyton and Associates (1958) discussed the possibility of movement of water to Barton Springs from the Edwards aquifer south of the study area. This movement probably occurs within the confined part of the "bad-water" and freshwater zones. The possibility of this ocurrence can be demonstrated by water-budget analysis for the drought of 1955-56. During that drought, Barton Springs discharge dropped to about $10 \mathrm{ft}^{3} / \mathrm{s}$, which is the minimum measured flow of the springs since measurements were begun in 1894. No streamflow data are available for the recharge creeks during the drought period. However, periodic discharge measurements made of Onion Creek at a site near the upstream end of the recharge zone have shown that the creek was dry many times since 1961. Also, recorded periods of no flow have been observed at all the other streamflow-gaging stations on the recharge creeks; thus, all those streams have intermittent flow. The drought was the most severe ever recorded in over 100 years: as a result, all six of the recharge creeks probably were dry for most, if not all, of the the 2-year period.

The potentiometric surface during 1978, when Barton Springs was discharging $20 \mathrm{ft} 3 / \mathrm{s}$, is shown in figure 18. At the end of 1954, which marked the beginning of the 2-year drought, Barton Springs also was discharging about 20 $\mathrm{ft}^{3} / \mathrm{s}$. Ground-water pumpage and withdrawal patterns probably had not changed substantially from 1954 to 1978, therefore, the water levels in 1978 (fig. 18) are probably representative of water levels in 1954. The potentiometric surface during 1956 (fig. 17), near the end of the drought, was very similar to the water levels assumed during 1954; thus water-level declines within the aquifer or the "bad-water" zone east of the study area during the drought could not account for the 21,000 acre-ft of water that discharged from Barton Springs during that period. Because there was little, if any, recharge from creeks during that period, the discharge at Barton Springs must have been sustained by the subsurface movement of water from the adjacent Trinity aquifer, or from the "bad-water" and freshwater zones of the Edwards aquifer south of the study area, or both.

The sodium and chloride concentrations in a water sample collected from Barton Springs during the drought in 1955 (table 7) were 40 and $64 \mathrm{mg} / \mathrm{L}$, respectively. These sodium and chloride concentrations are higher than any of those ever found in wells in the upper Trinity aquifer near the study area. However, several wells in the "bad-water" zone east and southeast of the study area have sodium and chloride levels much higher than those found at Barton Springs in 1955. This suggests that some of the suspected subsurface recharge could have come from the "bad-water" zone of the Edwards aquifer south of the study area.

Ground-water levels during 1956 in many wells in the confined part of the Edwards aquifer in Hays County are presented by DeCook (1960, p. 56). Those levels show a small water-level gradient in the confined part of the aquifer from San Marcos ( $9 \mathrm{mi}$ south of Kyle) to Buda, which indicates the possibility of water movement into the study area from the Edwards aquifer south of the study area at that time.

While there is evidence of subsurface recharge to the Edwards aquifer from the Trinity aquifer and from the Edwards aquifer south of the study area, this 
evidence al so suggests that the amount of this recharge, when compared to recharge from the surface, is 1 imited. Only 13 of 140 well is developed in the Edwards aquifer show evidence of leakage from the underlying Trinity aquifer. As stated in the "Upward Leakage" section, all of the wells indicating leakage are along faults, where vertical permeability is probably much greater than lateral permeability normal to the faults, thus, pumpage could be delivering water from the Trinity aquifer that is not in circulation in the Edwards aquifer. Ground-water fl ow into the study area from the Edwards aquifer to the south probably is 1 imited al so. The evidence presented for this movement occurred during a drought which was probably the most severe in over 100 years, thus this flow could be limited to extreme drought conditions. The water qual ity of Barton Springs and most wells in the Edwards aquifer is usually indicative only of Edwards aquifer water. The only times that the quality of Barton Springs indicates the presence of water other than from the recharge area is during very low flow conditions. Even then, the qual ity of water from the springs indicate that the leakage is only a small part of the springflow.

\section{Discharge}

Discharge from the Edwards aquifer study area is composed of springflow, pumpage, and possibly subsurface discharge. Values for springfl ow and pumpage are presented in this section. Subsurface discharge is discussed in this section and in the section "Water-Budget Analys is".

\section{Subsurface Flow}

Ground-water levels in the confined part of the Edwards aquifer between Buda and San Marcos (about $15 \mathrm{mi}$ south of Buda) were reviewed in order to identify ground-water gradients in that area. The Texas Department of Water Resources has measured about 15 wells in that area; the frequency and period of record of the measurements vary between the wells (Howard Taylor, Texas Department of Water Resources, written commun., 1983). The Geological Survey has measured about 12 wells annually from 1978 to 1982 in the confined zone of the aquifer between Buda and Kyle (fig. 14). The ground-water level s for about 20 periods from 1956 to 1982 were reviewed in order to determine the direction, if any, of the ground-water gradient between San Marcos and Buda. Only one period, the 1956 period, was identified for which the gradient was from south to north. The ground-water conditions during that period are discussed in the preceeding section. However, in each of the other periods reviewed, there was a small ground-water gradient in that area from north to south, indicating the possibility of water movement from the study area into the Edwards aquifer south of the study area, where discharges occur at San Marcos Springs in San Marcos. The rates for this subsurface flow, if occurring, are unknown. 0ther possible sources of subsurface discharge are discussed in the "Water-Budget Analys is" section.

\section{Springfl ow}

Several springs discharge from the Edwards aquifer in topographically low areas near Town Lake in Austin. Cold and Deep Eddy Springs, near Valley Springs Road in Austin (fig. 22), consistently fl ow between 3 and $4 \mathrm{ft}^{3} / \mathrm{s}$ (Brune, 1975). These springs discharge the Rollingwood area of the Edwards aquifer labout 4 
mi2). Fault barriers between Barton Springs and Rollingwood probably separate the aquifer hydrologically (see "Ground-Water Flow System" section). Recharge from Dry Creek probably feeds the Rollingwood area of the Edwards aquifer.

The remaining area of the Edwards aquifer (about $151 \mathrm{mi}^{2}$ ) supplic.s water to Barton Springs and several intermittently flowing springs. The intermittently flowing springs are in the creek bed of Barton Creek between loop 360 and Barton Springs. These springs flow only about 30 percent of the time, when ground-water levels are above the bottom of the creek at these locations. Their discharge is as much as about $6 \mathrm{ft}^{3} / \mathrm{s}$. Barton Springs discharge accounts for about 96 percent of the springflow from this part of the aquifer.

Barton Springs discharges to Barton Creek, just upstream trom its mouth, and then to Town Lake (fig. 22). The mouth of Barton Creek is about $0.5 \mathrm{mi}$ upstream from the Green Water Treatment Plant; one of three plants which treat and deliver the municipal water supply for the city of Austin. Water from Barton Springs is one of three inflow sources to Town Lake. Inflow to Town Lake comes from outflow from Lake Austin, local runoff from the watersheds which contribute directly to Town Lake, and from Barton Springs. Outflow from Lake Austin often varies from 0 in the fall months to 1,000 to $3,000 \mathrm{ft}^{3} / \mathrm{s}$ during other months; local runoff usually varies from 1 ess than $1 \mathrm{ft}^{3} / \mathrm{s}$ during dry months to several thousand cubic feet per second during heavy storms; and discharge from Barton Springs has varied from about 10 to $166 \mathrm{ft}^{3} / \mathrm{s}$. The contribution of Barton Springs to inflow from Town Lake, therefore, often varies daily from less than 1 percent to greater than 90 percent.

Beginning in 1894, periodic measurements were made of the discharge of Barton Springs, and beginning in 1917, more frequent measurements of springflow have been made. Barton Springs include five major springs, three of which discharge into the pool. The other two springs, locally named Concession Springs and 01d Mill Springs, discharge into Barton Creek just downstream 1rom the po01. In March 1978, a water-1evel recorder was installed in well YD-58-42-903, about $200 \mathrm{ft}$ from the main springs. The correlation between the water levels in that well and the flow of Barton Springs when the pool is drained and when it is full is shown in figure 36 . The correlations are based on measured discharges of Barton Springs and corresponding measurements of water levels in the we11.

Discharge measurements of Concession and $01 \mathrm{~d}$ Mill Springs were used to determine the relationship between springflow entering the pool and total springflow, which is indicated in figure 36 . Depending on flow conditions and whether the pool is full or drained, between 55 and 82 percent of total springflow discharges into the pool. The recorder on the well produce, hourly water-level readings, which are used with the water-level-di,charge relationship to compute the total daily-mean flows for Barton Springs. These dailymean values of discharge are published in the annual report series by S1ade and others $(1980,1981,1982,1983,1984)$ and Gordon and others (1985). Typical hydrographs of daily-mean discharges of Barton Springs are shown in figures 29-31.

The monthly-mean and annual-mean values of discharge for Barton Springs for 1917-82 have been estimated based on 725 discharge measurements made during 1917-78, and computed for 1979-82 based on daily-mean flows. Precipitation records for the city of Austin, published by the National Weather Service, 


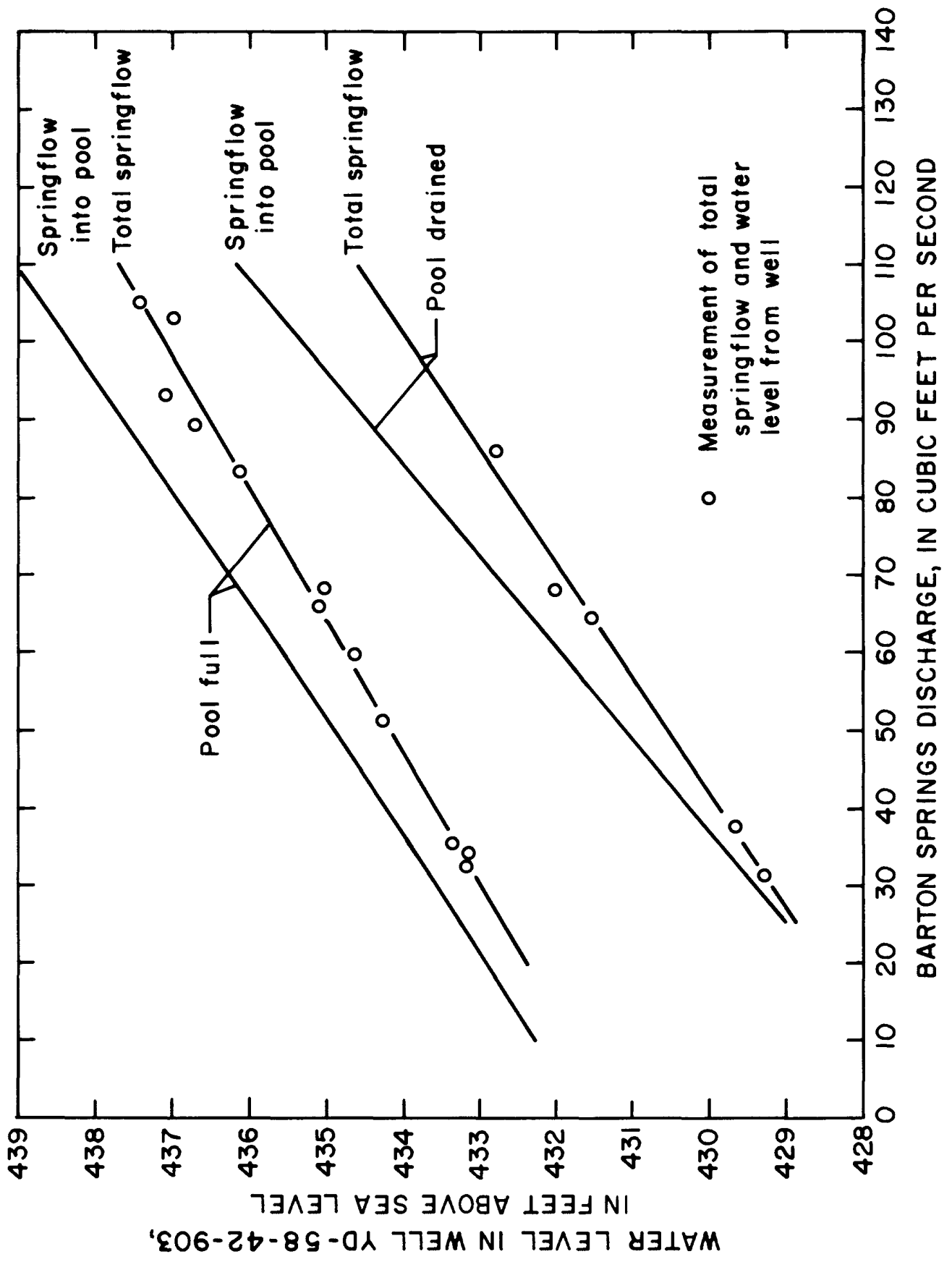

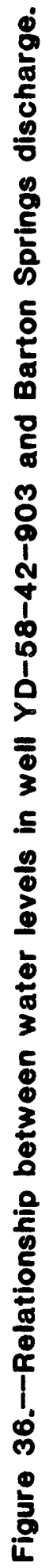


were used to assist in estimating the flow between the discharge measurements during the 1917-82 period. These monthly- and annual-mean discharge values for Barton Springs are presented in table 6.

Based on the monthly-mean flows from 1917-82, the mean discharge of Barton Springs is $50 \mathrm{ft}^{3} / \mathrm{s}$, and the median discharge is $46 \mathrm{ft}^{3} / \mathrm{s}$. The maximum and minimum measured flows are 166 and $10 \mathrm{ft}^{3} / \mathrm{s}$, respectively. The monthly-mean discharges also were used to develop the flow-duration curve for Barton Springs shown in figure 37. This curve presents percentages of time that given monthiymean discharges are equaled or exceeded. For example, a monthly-mean value of $100 \mathrm{ft}^{3} / \mathrm{s}$ is equaled or exceeded only 5 percent of the time, and thus, $95 \mathrm{per}-$ cent of the time the monthly-mean flow of Barton Springs is less than 100 $\mathrm{ft}^{3} / \mathrm{s}$. Except during extreme high-flow conditions, the discharge for Barton Springs generally recedes slowly with time. Although the flow-duration statistics are based on monthly-mean values, they probably also represent instantaneous flow conditions, except for flows greater than $100 \mathrm{ft}^{3} / \mathrm{s}$. Because the duration of high discharges is relatively short, the monthly-mean statistics probably do not represent those values. The slope of the curve is significantly flatter for flows less than $25 \mathrm{ft}^{3} / \mathrm{s}$. The curve approaches a line tangent to a discharge of about $10 \mathrm{ft}^{3} / \mathrm{s}$ indicating a minimum flow for Barton Springs.

\section{Pumpage}

Several hundred wells in the study area supply water for municipal (including public supply), industrial, domestic, and agricultural (1ivestock and irrigation) use. As of 1982, there were 25 major well fields identified in the study area with a total pumpage of about 2,900 acre-ft during that year for municipal and industrial use. Only a few of the major ground-water developers have a metering system for determining the volume of pumpage, so most of the major pumpage is estimated. Total pumpage from the remaining wells, which are used mostly for domestic or agricultural purposes, has been estimated by the Texas Department of Water Resources to average about 900 acre-ft per year. This estimated total pumpage of about 3,800 acre-ft per year represents a meandaily use of just over $5 \mathrm{ft}^{3} / \mathrm{s}$. The municipal, industrial, domestic, and agricultural uses are 43 percent, 33 percent, 20 percent, and 4 percent of total pumpage, respectively.

The estimated-mean pumpage of $5 \mathrm{ft}^{3} / \mathrm{s}$ is about 10 percent of the longterm mean discharge of $50 \mathrm{ft}^{3} / \mathrm{s}$ for Barton Springs. During periods of average or high ground-water levels in the aquifer, pumpage probably has only a small effect on ground-water levels and on the discharge of Barton Springs. During dry conditions when ground-water levels are low, pumpage effects on the water levels and on Barton Springs discharge are greater.

High rates of pumpage may cause substantial subsurface recharge from the Trinity aquifer or the "bad-water" zone of the Edwards aquifer, or both. A ground-water divide that approximates the southern boundary of the study area al so may be affected. Lowering of the potentiometric surface near this boundary may cause water movement within the Edwards aquifer to occur across the boundary.

The water supply of the aquifer currently (1985) is sufficient to meet the demands of the estimated 30,000 people who use water from this source. How 


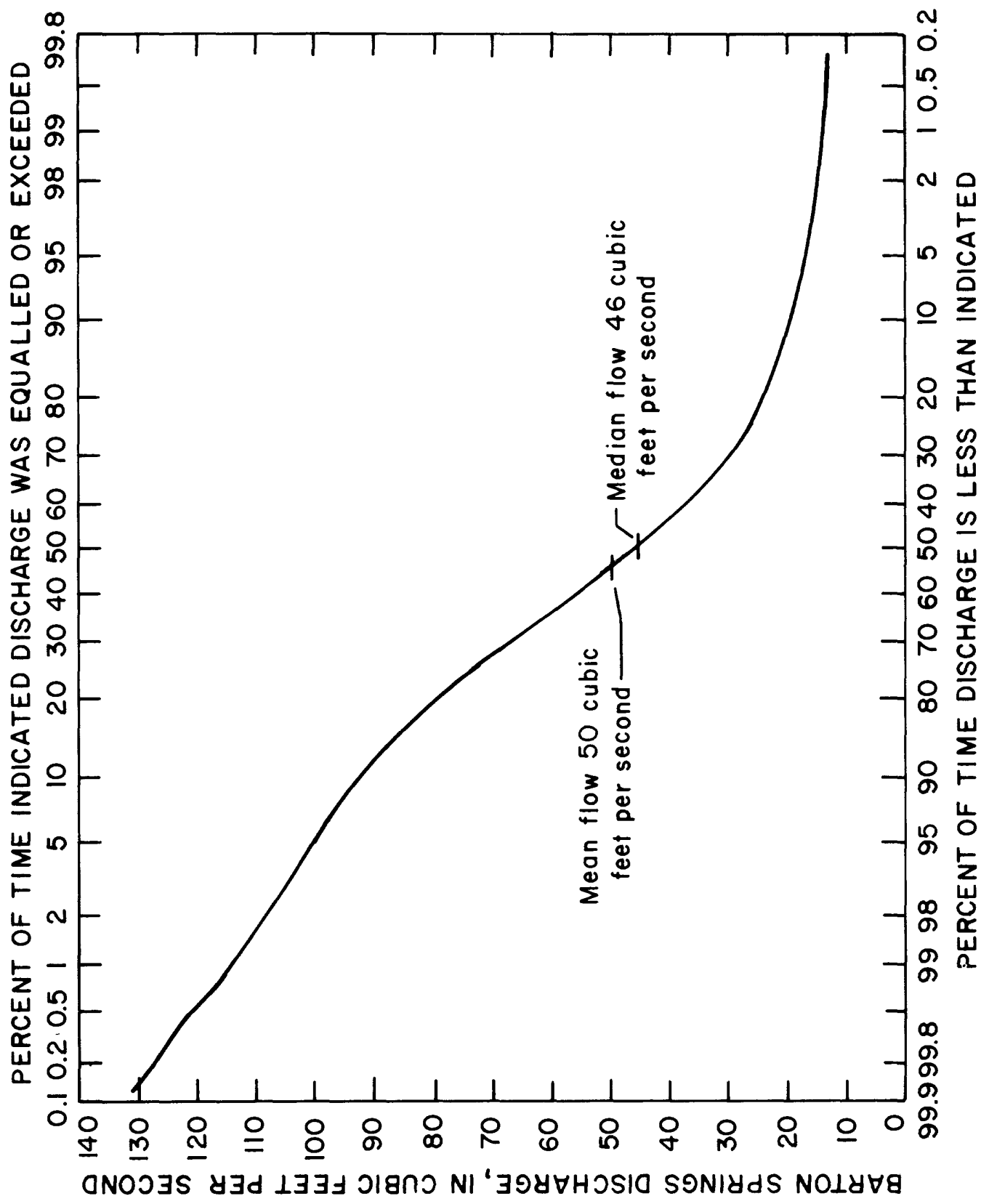


Table 6.--Monthly- and annual-mean discharges for Barton Springs, 1917-82

$$
\text { [ } \mathrm{ft}^{3} / \mathrm{s} \text {, cubic foot per second] }
$$

\begin{tabular}{|c|c|c|c|c|c|c|c|c|c|c|c|c|c|}
\hline \multirow{2}{*}{ Year } & \multicolumn{12}{|c|}{ Monthly-mean discharge $\left(\mathrm{ft}^{3} / \mathrm{s}\right)$} & \multirow{2}{*}{$\begin{array}{c}\text { Annual- } \\
\text { mean } \\
\text { discharge } \\
\left(\mathrm{ft}^{3} / \mathrm{s}\right)\end{array}$} \\
\hline & Jan. & Feb. & Mar. & Apr. & May & June & Juty & Aug. & Sept. & oct. & Nov. & Dec. & \\
\hline $\begin{array}{l}1917 \\
1918 \\
1919 \\
1920\end{array}$ & $\begin{array}{r}20 \\
13 \\
25 \\
110\end{array}$ & $\begin{array}{l}18 \\
14 \\
45 \\
96\end{array}$ & $\begin{array}{l}16 \\
13 \\
54 \\
76\end{array}$ & $\begin{array}{l}15 \\
21 \\
69 \\
72\end{array}$ & $\begin{array}{l}15 \\
19 \\
85 \\
80\end{array}$ & $\begin{array}{l}18 \\
16 \\
76 \\
75\end{array}$ & $\begin{array}{l}16 \\
15 \\
67 \\
60\end{array}$ & $\begin{array}{l}15 \\
14 \\
53 \\
65\end{array}$ & $\begin{array}{l}18 \\
13 \\
57 \\
64\end{array}$ & $\begin{array}{r}15 \\
14 \\
105 \\
50\end{array}$ & $\begin{array}{r}14 \\
18 \\
104 \\
42\end{array}$ & $\begin{array}{l}14 \\
15 \\
78 \\
37\end{array}$ & $\begin{array}{l}16 \\
15 \\
68 \\
69\end{array}$ \\
\hline $\begin{array}{l}1921 \\
1922 \\
1923 \\
1924 \\
1925\end{array}$ & $\begin{array}{l}35 \\
32 \\
23 \\
88 \\
30\end{array}$ & $\begin{array}{l}32 \\
30 \\
24 \\
85 \\
28\end{array}$ & $\begin{array}{l}40 \\
29 \\
24 \\
85 \\
24\end{array}$ & $\begin{array}{r}110 \\
110 \\
55 \\
92 \\
24\end{array}$ & $\begin{array}{l}72 \\
90 \\
50 \\
98 \\
23\end{array}$ & $\begin{array}{r}52 \\
70 \\
39 \\
103 \\
22\end{array}$ & $\begin{array}{l}48 \\
56 \\
30 \\
87 \\
23\end{array}$ & $\begin{array}{l}34 \\
43 \\
24 \\
82 \\
19\end{array}$ & $\begin{array}{l}55 \\
35 \\
32 \\
65 \\
16\end{array}$ & $\begin{array}{l}57 \\
26 \\
30 \\
50 \\
25\end{array}$ & $\begin{array}{l}45 \\
30 \\
53 \\
42 \\
65\end{array}$ & $\begin{array}{l}38 \\
25 \\
75 \\
32 \\
37\end{array}$ & $\begin{array}{l}52 \\
48 \\
38 \\
76 \\
28\end{array}$ \\
\hline $\begin{array}{l}1926 \\
1927 \\
1928 \\
1929 \\
1930\end{array}$ & $\begin{array}{l}45 \\
34 \\
28 \\
22 \\
22\end{array}$ & $\begin{array}{l}48 \\
32 \\
32 \\
19 \\
24\end{array}$ & $\begin{array}{l}55 \\
40 \\
53 \\
21 \\
29\end{array}$ & $\begin{array}{l}75 \\
48 \\
32 \\
38 \\
22\end{array}$ & $\begin{array}{l}93 \\
43 \\
32 \\
40 \\
50\end{array}$ & $\begin{array}{l}80 \\
39 \\
33 \\
82 \\
42\end{array}$ & $\begin{array}{l}67 \\
34 \\
24 \\
72 \\
36\end{array}$ & $\begin{array}{l}54 \\
25 \\
19 \\
51 \\
24\end{array}$ & $\begin{array}{l}43 \\
20 \\
18 \\
38 \\
21\end{array}$ & $\begin{array}{l}41 \\
30 \\
17 \\
31 \\
42\end{array}$ & $\begin{array}{l}37 \\
29 \\
20 \\
30 \\
35\end{array}$ & $\begin{array}{l}35 \\
24 \\
21 \\
26 \\
55\end{array}$ & $\begin{array}{l}56 \\
33 \\
27 \\
39 \\
34\end{array}$ \\
\hline $\begin{array}{l}1931 \\
1932 \\
1933 \\
1934 \\
1935\end{array}$ & $\begin{array}{l}52 \\
33 \\
30 \\
25 \\
23\end{array}$ & $\begin{array}{l}82 \\
30 \\
27 \\
60 \\
23\end{array}$ & $\begin{array}{l}91 \\
47 \\
34 \\
52 \\
31\end{array}$ & $\begin{array}{l}88 \\
44 \\
30 \\
70 \\
23\end{array}$ & $\begin{array}{l}93 \\
37 \\
25 \\
62 \\
45\end{array}$ & $\begin{array}{l}72 \\
33 \\
25 \\
56 \\
91\end{array}$ & $\begin{array}{l}60 \\
27 \\
24 \\
34 \\
78\end{array}$ & $\begin{array}{l}50 \\
24 \\
27 \\
27 \\
58\end{array}$ & $\begin{array}{l}40 \\
26 \\
25 \\
23 \\
56\end{array}$ & $\begin{array}{l}35 \\
23 \\
24 \\
21 \\
52\end{array}$ & $\begin{array}{l}30 \\
21 \\
21 \\
22 \\
40\end{array}$ & $\begin{array}{l}25 \\
23 \\
23 \\
22 \\
35\end{array}$ & $\begin{array}{l}60 \\
31 \\
26 \\
40 \\
46\end{array}$ \\
\hline $\begin{array}{l}1936 \\
1937 \\
1938 \\
1939 \\
1940\end{array}$ & $\begin{array}{l}31 \\
62 \\
52 \\
23 \\
13\end{array}$ & $\begin{array}{l}30 \\
46 \\
70 \\
23 \\
16\end{array}$ & $\begin{array}{l}20 \\
59 \\
66 \\
18 \\
16\end{array}$ & $\begin{array}{l}22 \\
44 \\
60 \\
19 \\
15\end{array}$ & $\begin{array}{l}20 \\
49 \\
85 \\
17 \\
18\end{array}$ & $\begin{array}{l}42 \\
64 \\
65 \\
12 \\
19\end{array}$ & $\begin{array}{l}70 \\
45 \\
54 \\
16 \\
47\end{array}$ & $\begin{array}{l}43 \\
34 \\
44 \\
17 \\
38\end{array}$ & $\begin{array}{l}45 \\
30 \\
34 \\
16 \\
25\end{array}$ & $\begin{array}{l}48 \\
26 \\
25 \\
16 \\
25\end{array}$ & $\begin{array}{l}43 \\
24 \\
24 \\
16 \\
26\end{array}$ & $\begin{array}{l}47 \\
30 \\
24 \\
14 \\
75\end{array}$ & $\begin{array}{l}38 \\
43 \\
50 \\
17 \\
28\end{array}$ \\
\hline $\begin{array}{l}1941 \\
1942 \\
1943 \\
1944 \\
1945\end{array}$ & $\begin{array}{l}70 \\
36 \\
49 \\
38 \\
81\end{array}$ & $\begin{array}{l}70 \\
35 \\
40 \\
64 \\
83\end{array}$ & $\begin{array}{l}66 \\
27 \\
38 \\
83 \\
82\end{array}$ & $\begin{array}{r}125 \\
49 \\
48 \\
79 \\
93\end{array}$ & $\begin{array}{r}115 \\
47 \\
42 \\
86 \\
104\end{array}$ & $\begin{array}{r}110 \\
28 \\
42 \\
85 \\
85\end{array}$ & $\begin{array}{l}87 \\
31 \\
43 \\
70 \\
77\end{array}$ & $\begin{array}{l}90 \\
26 \\
32 \\
51 \\
64\end{array}$ & $\begin{array}{l}73 \\
53 \\
28 \\
45 \\
51\end{array}$ & $\begin{array}{l}58 \\
75 \\
32 \\
38 \\
40\end{array}$ & $\begin{array}{l}48 \\
65 \\
28 \\
30 \\
44\end{array}$ & $\begin{array}{l}42 \\
57 \\
23 \\
45 \\
44\end{array}$ & $\begin{array}{l}80 \\
44 \\
37 \\
60 \\
71\end{array}$ \\
\hline $\begin{array}{l}1946 \\
1947 \\
1948 \\
1949 \\
1950\end{array}$ & $\begin{array}{l}52 \\
80 \\
26 \\
20 \\
18\end{array}$ & $\begin{array}{l}65 \\
83 \\
24 \\
20 \\
26\end{array}$ & $\begin{array}{l}81 \\
90 \\
23 \\
24 \\
30\end{array}$ & $\begin{array}{l}76 \\
95 \\
21 \\
52 \\
35\end{array}$ & $\begin{array}{l}90 \\
82 \\
20 \\
45 \\
55\end{array}$ & $\begin{array}{l}83 \\
70 \\
19 \\
40 \\
51\end{array}$ & $\begin{array}{l}66 \\
56 \\
25 \\
32 \\
39\end{array}$ & $\begin{array}{l}52 \\
35 \\
19 \\
23 \\
29\end{array}$ & $\begin{array}{l}47 \\
37 \\
23 \\
20 \\
25\end{array}$ & $\begin{array}{l}64 \\
48 \\
27 \\
20 \\
20\end{array}$ & $\begin{array}{l}85 \\
29 \\
19 \\
19 \\
23\end{array}$ & $\begin{array}{l}74 \\
27 \\
19 \\
18 \\
23\end{array}$ & $\begin{array}{l}70 \\
61 \\
22 \\
28 \\
31\end{array}$ \\
\hline $\begin{array}{l}1951 \\
1952 \\
1953 \\
1954 \\
1955\end{array}$ & $\begin{array}{l}17 \\
13 \\
50 \\
64 \\
21\end{array}$ & $\begin{array}{l}17 \\
13 \\
52 \\
50 \\
20\end{array}$ & $\begin{array}{l}17 \\
15 \\
48 \\
37 \\
20\end{array}$ & $\begin{array}{l}18 \\
30 \\
50 \\
31 \\
15\end{array}$ & $\begin{array}{l}20 \\
29 \\
52 \\
30 \\
21\end{array}$ & $\begin{array}{l}38 \\
27 \\
38 \\
24 \\
19\end{array}$ & $\begin{array}{l}16 \\
22 \\
21 \\
19 \\
16\end{array}$ & $\begin{array}{l}15 \\
18 \\
17 \\
18 \\
14\end{array}$ & $\begin{array}{l}20 \\
30 \\
47 \\
16 \\
16\end{array}$ & $\begin{array}{l}16 \\
34 \\
36 \\
21 \\
15\end{array}$ & $\begin{array}{l}16 \\
33 \\
63 \\
22 \\
15\end{array}$ & $\begin{array}{l}16 \\
34 \\
70 \\
21 \\
14\end{array}$ & $\begin{array}{l}19 \\
25 \\
45 \\
29 \\
17\end{array}$ \\
\hline $\begin{array}{l}1956 \\
1957 \\
1958 \\
1959 \\
1960\end{array}$ & $\begin{array}{l}16 \\
15 \\
75 \\
80 \\
62\end{array}$ & $\begin{array}{l}14 \\
15 \\
88 \\
70 \\
78\end{array}$ & $\begin{array}{r}14 \\
14 \\
123 \\
60 \\
70\end{array}$ & $\begin{array}{l}12 \\
19 \\
95 \\
70 \\
65\end{array}$ & $\begin{array}{l}13 \\
53 \\
75 \\
70 \\
57\end{array}$ & $\begin{array}{l}12 \\
77 \\
90 \\
62 \\
55\end{array}$ & $\begin{array}{l}11 \\
50 \\
84 \\
57 \\
46\end{array}$ & $\begin{array}{l}11 \\
32 \\
62 \\
34 \\
50\end{array}$ & $\begin{array}{l}12 \\
70 \\
58 \\
43 \\
52\end{array}$ & $\begin{array}{l}13 \\
50 \\
65 \\
65 \\
46\end{array}$ & $\begin{array}{r}15 \\
70 \\
83 \\
55 \\
105\end{array}$ & $\begin{array}{l}12 \\
91 \\
80 \\
50 \\
92\end{array}$ & $\begin{array}{l}13 \\
46 \\
82 \\
60 \\
65\end{array}$ \\
\hline $\begin{array}{l}1961 \\
1962 \\
1963 \\
1964 \\
1965\end{array}$ & $\begin{array}{l}89 \\
54 \\
47 \\
20 \\
55\end{array}$ & $\begin{array}{l}97 \\
58 \\
50 \\
21 \\
69\end{array}$ & $\begin{array}{l}99 \\
58 \\
47 \\
22 \\
66\end{array}$ & $\begin{array}{l}96 \\
60 \\
62 \\
26 \\
63\end{array}$ & $\begin{array}{l}88 \\
56 \\
55 \\
21 \\
80\end{array}$ & $\begin{array}{l}79 \\
49 \\
41 \\
21 \\
95\end{array}$ & $\begin{array}{r}130 \\
38 \\
40 \\
20 \\
84\end{array}$ & $\begin{array}{r}135 \\
40 \\
33 \\
19 \\
75\end{array}$ & $\begin{array}{r}118 \\
46 \\
24 \\
18 \\
78\end{array}$ & $\begin{array}{r}107 \\
41 \\
21 \\
19 \\
86\end{array}$ & $\begin{array}{l}93 \\
36 \\
20 \\
19 \\
85\end{array}$ & $\begin{array}{l}78 \\
36 \\
19 \\
19 \\
82\end{array}$ & $\begin{array}{r}101 \\
48 \\
38 \\
20 \\
76\end{array}$ \\
\hline
\end{tabular}


Table 6.--Monthly- and annual-mean discharges for Barton Springs, 1917-82--Continued

\begin{tabular}{|c|c|c|c|c|c|c|c|c|c|c|c|c|c|}
\hline \multirow[t]{2}{*}{ Year } & \multicolumn{12}{|c|}{ Monthly-mean discharge $\left(\mathrm{ft}^{3} / \mathrm{s}\right)$} & \multirow{2}{*}{$\begin{array}{c}\text { Annual- } \\
\text { mean } \\
\text { discharge } \\
\left(\mathrm{ft}^{3} / \mathrm{s}\right) \\
\end{array}$} \\
\hline & Jan. & Feb. & Mar. & Apr. & May & June & July & Aug. & Sept. & Oct. & Nov. & Dec. & \\
\hline $\begin{array}{l}1966 \\
1967 \\
1968 \\
1969 \\
1970\end{array}$ & $\begin{array}{l}82 \\
28 \\
76 \\
50 \\
47\end{array}$ & $\begin{array}{r}80 \\
28 \\
100 \\
64 \\
82\end{array}$ & $\begin{array}{r}78 \\
28 \\
97 \\
74 \\
111\end{array}$ & $\begin{array}{r}77 \\
30 \\
87 \\
73 \\
110\end{array}$ & $\begin{array}{r}75 \\
27 \\
89 \\
78 \\
103\end{array}$ & $\begin{array}{l}71 \\
21 \\
86 \\
73 \\
98\end{array}$ & $\begin{array}{l}60 \\
15 \\
89 \\
67 \\
93\end{array}$ & $\begin{array}{l}47 \\
22 \\
85 \\
61 \\
88\end{array}$ & $\begin{array}{l}44 \\
38 \\
77 \\
56 \\
84\end{array}$ & $\begin{array}{l}39 \\
61 \\
68 \\
51 \\
78\end{array}$ & $\begin{array}{l}30 \\
48 \\
59 \\
46 \\
65\end{array}$ & $\begin{array}{l}25 \\
42 \\
54 \\
43 \\
51\end{array}$ & $\begin{array}{l}59 \\
32 \\
81 \\
61 \\
84\end{array}$ \\
\hline $\begin{array}{l}1971 \\
1972 \\
1973 \\
1974 \\
1975\end{array}$ & $\begin{array}{r}39 \\
100 \\
71 \\
95 \\
96\end{array}$ & $\begin{array}{l}35 \\
96 \\
69 \\
93 \\
97\end{array}$ & $\begin{array}{l}32 \\
90 \\
68 \\
90 \\
96\end{array}$ & $\begin{array}{l}28 \\
86 \\
65 \\
93 \\
95\end{array}$ & $\begin{array}{l}31 \\
84 \\
64 \\
95 \\
97\end{array}$ & $\begin{array}{r}33 \\
88 \\
74 \\
89 \\
113\end{array}$ & $\begin{array}{r}20 \\
85 \\
87 \\
82 \\
118\end{array}$ & $\begin{array}{r}35 \\
81 \\
89 \\
73 \\
112\end{array}$ & $\begin{array}{l}67 \\
80 \\
87 \\
66 \\
99\end{array}$ & $\begin{array}{l}71 \\
80 \\
98 \\
65 \\
90\end{array}$ & $\begin{array}{r}73 \\
77 \\
108 \\
74 \\
82\end{array}$ & $\begin{array}{l}77 \\
74 \\
99 \\
98 \\
73\end{array}$ & $\begin{array}{l}45 \\
85 \\
82 \\
84 \\
97\end{array}$ \\
\hline $\begin{array}{l}1976 \\
1977 \\
1978 \\
1979 \\
1980\end{array}$ & $\begin{array}{l}64 \\
98 \\
39 \\
64 \\
38\end{array}$ & $\begin{array}{l}58 \\
99 \\
42 \\
79 \\
37\end{array}$ & $\begin{array}{r}55 \\
100 \\
38 \\
84 \\
35\end{array}$ & $\begin{array}{r}70 \\
103 \\
31 \\
95 \\
42\end{array}$ & $\begin{array}{r}113 \\
106 \\
31 \\
103 \\
62\end{array}$ & $\begin{array}{r}106 \\
101 \\
31 \\
106 \\
71\end{array}$ & $\begin{array}{r}100 \\
94 \\
21 \\
98 \\
57\end{array}$ & $\begin{array}{l}93 \\
88 \\
22 \\
93 \\
42\end{array}$ & $\begin{array}{l}88 \\
80 \\
25 \\
84 \\
37\end{array}$ & $\begin{array}{l}90 \\
72 \\
24 \\
69 \\
46\end{array}$ & $\begin{array}{l}97 \\
62 \\
33 \\
55 \\
43\end{array}$ & $\begin{array}{l}98 \\
50 \\
36 \\
46 \\
50\end{array}$ & $\begin{array}{l}86 \\
88 \\
31 \\
81 \\
47\end{array}$ \\
\hline $\begin{array}{l}1981 \\
1982\end{array}$ & $\begin{array}{l}48 \\
60\end{array}$ & $\begin{array}{l}53 \\
52\end{array}$ & $\begin{array}{l}66 \\
46\end{array}$ & $\begin{array}{l}64 \\
43\end{array}$ & $\begin{array}{l}58 \\
62\end{array}$ & $\begin{array}{l}81 \\
68\end{array}$ & $\begin{array}{r}102 \\
57\end{array}$ & $\begin{array}{l}94 \\
44\end{array}$ & $\begin{array}{l}86 \\
36\end{array}$ & $\begin{array}{l}86 \\
33\end{array}$ & $\begin{array}{l}83 \\
34\end{array}$ & $\begin{array}{l}74 \\
41\end{array}$ & $\begin{array}{l}75 \\
48\end{array}$ \\
\hline
\end{tabular}

1/ Monthly-mean discharges from 1917 through February 1978 are estimated values based on discharge measurements and rainfall values. Beginning March 1978, monthly-mean discharges are based on gaged values of daily-mean discharge. 
ever, as the aquifer is further developed with wells, the resulting increase in ground-water pumpage will result in proportional reductions in the quantity of ground water in storage and the discharge of Barton Springs.

Population-growth projections done by the city of Austin show that about 86,000 more people will be living in the aquifer area between 1980 and the year 2000 (Planning and Growth Managment Department, City of Austin, written commun., 1984). The water demand for this growth may exceed the resources of the Edwards aquifer particularly in site specific areas. The effect of this growth on ground-water levels and on Barton Springs discharge depends upon the extent that the Edwards aquifer is used to provide the water demand. A mathematical simulation of the effect of this population increase on future groundwater levels in the aquifer is presented by Slade and others (1985).

Decline in ground-water levels due to heavy pumpage is the largest cause of springflow declines in Texas. Brune $(1975,1981)$ presented several examples of springs in the State that have reduced flows or have ceased flowing due to pumpage. Of the 17 springs that historically were the largest in Texas, 4 either have ceased flowing or have significant declines in discharge. The largest of these four springs is San Antonio Springs, which discharged from the Edwards aquifer in Bexar County and had an average discharge comparable to Barton Springs. Near San Antonio Springs, very large quantities of water are pumped for municipal and industrial use, and the declines in ground-water levels have caused this spring to cease flowing much of the time.

\section{Water-Budget Analysis}

Recharge (inflow) and dischàge (outflow) for any hydrologic system may be compared for purposes of water-volume accounting. The generalized hydrologic equation for a water-budget analysis is stated as:

$$
R-D=\Delta S \text {, }
$$

where $R=$ recharge during a given period,

$D=$ discharge during the period, and

$\Delta S=$ change in storage during the period.

A water-budget analysis was performed for the ground-water basin which discharges to Barton Springs. Only those components of the budget which exist at the land surface and are known or reasonably estimated are considered (surface recharge, springflow, and pumpage). This analysis was done in order to compare the quantities of known recharge and discharge. Quantities of recharge and discharge in the subsurface are unknown, thus this analysis is not necessarily representative of total recharge and discharge.

The water-budget analysis was computed for the aquifer study area excluding the 4-mi2 Rollingwood area. In order to compare calculated recharge and discharge for the analysis, a period was chosen for which change in storage volume was minimal, that is, ground-water levels were similar for the beginning and end of the period. A 32-month period from December 1979-July 1982 was chosen for this analysis. A comparison of the recharge and discharge is shown in figure 38. The water levels in well YD-58-50-216 are also presented. The water levels in well YD-58-50-216 are representative of average water levels 

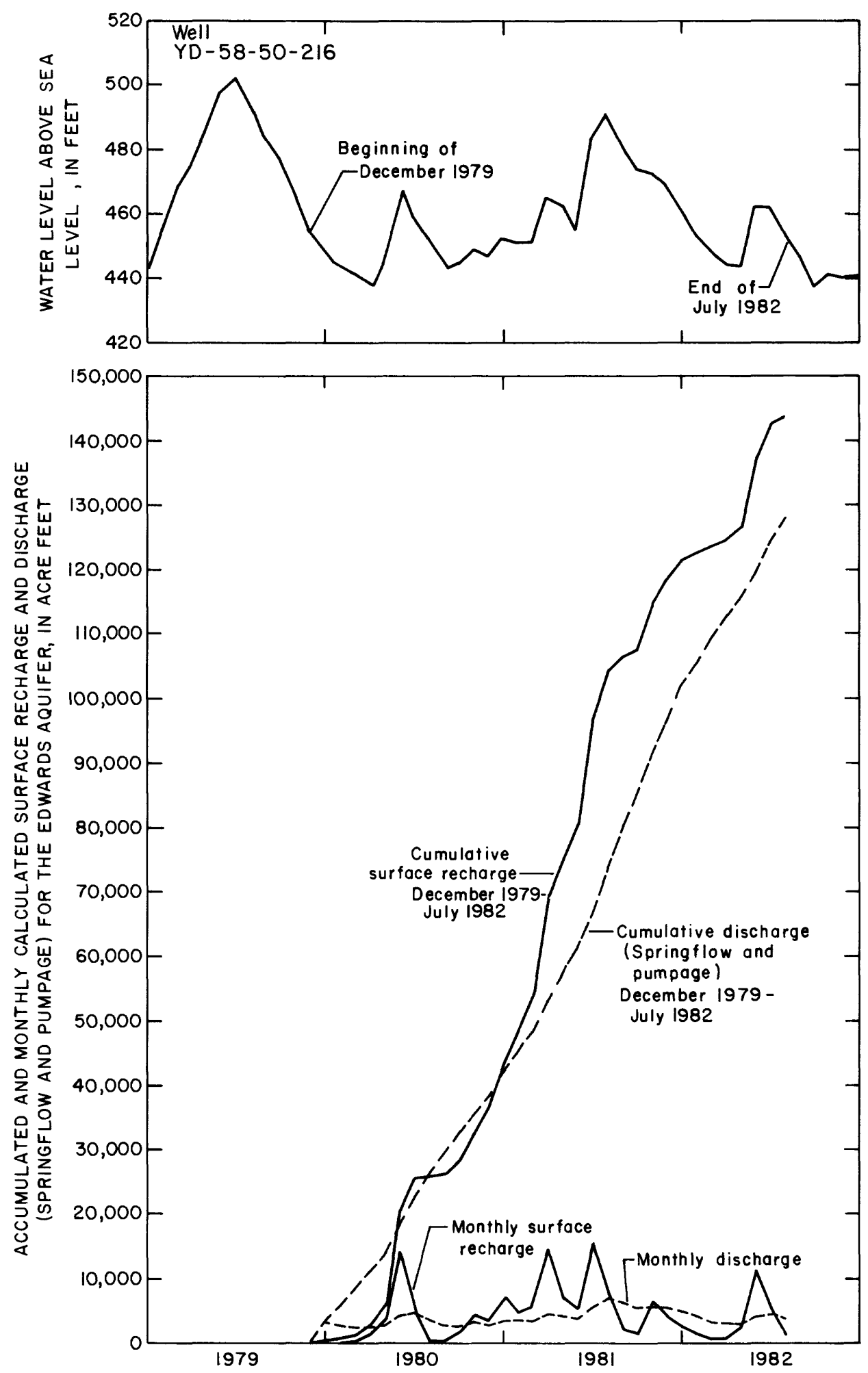

Figure 38.--Cumulative recharge and discharge for the Edwards aquifer. 
throughout the aquifer. As shown, the water levels at the beginning of December 1979 and at the end of July 1982 are comparable. Water levels in 18 other wells measured monthly in the aquifer also were very similar at the beginning and at the end of that period. Figure 38 also presents, beginning December 1979, the cumulative monthly surface recharge from the six watersheds serving the surface recharge area and the cumulative monthly discharge (springflow and pumpage). For the water-budget analysis, monthly discharge values for Barton Springs were increased by 4 percent to account for total springflow. Because the pumpage rates were about 3,800 acre-ft per year, about 300 acre-ft of monthly pumpage was added to the cumulative springflow values to obtain total monthly discharge. The total cumulative recharge and discharge for this period are about 144,000 and 128,000 acre-ft, respectively, thus calculated surface recharge exceeded discharge by 12 percent. This difference may be attributed to errors in estimating and calculating the components of the water budget.

Possible explanations of the discharge deficit also include the following:

1. Because most pumpage is estimated, underestimated pumpage could account for the discharge deficit.

2. A part of the calculated recharge from Barton Creek may flow into the Rollingwood part of the Edwards aquifer that bypasses Barton Springs and discharges at Cold and Deep Eddy Springs (see "Springflow" section). If that is the case, that part of the recharge should be excluded from the water-budget analysis for Barton Springs, which would lower the total recharge value. Barton Creek accounts for 28 percent of surface recharge, and the recharge excess is 12 percent. While it is possible that some of the recharge to Barton Creek may be discharged at Cold and Deep Eddy Springs, it is doubtful that this volume of water would be enough to account for the total discharge deficit. The deficit averages 500 acre-ft per month, and the total flow of Cold and Deep Eddy Springs is only about 210 acre-ft per month.

3. Part of the ground water recharged from Onion Creek may flow across the southern boundary of the study area to discharge at San Marcos Springs (see "Subsurface Flow" section). Onion Creek accounts for 34 percent of surface recharge, so most, if not all of this recharge probably moves to Barton Springs.

4. Some unaccounted springflow from the aquifer may be discharging directly into Town Lake. Because this springflow, if occurring, is inundated by Town Lake, its flow rate cannot be determined. If this occurs, however, the discharge probably would be very small. Flow-gain studies done on the Colorado River between Tom Miller Dam, which forms Lake Austin, and the Congress Avenue bridge indicate that Barton, Cold, and Deep Eddy Springs account for the total discharge gains in that reach (U.S. Geological Survey, written commun., 1916).

5. Leakage from the Edwards aquifer into an adjacent formation could be a source of outflow not included in this analysis.

Because the water-budget imbalance is small, the relative water volumes from any recharge or discharge sources that have not been taken into account would also be small compared to the volumes for the accounted sources.

This water-budget analysis showed a close balance between the components with known values (surface recharge, springflow, and pumpage). For the period selected, however, the mean discharge of Barton Springs was about $59 \mathrm{ft}^{3} / \mathrm{s}$ or 9 $\mathrm{ft}^{3} / \mathrm{s}$ greater than its long-term mean discharge. There may not be a balance between the known components within a period for which the mean values of the known components are significantly larger or smaller. Also, the analysis is 
not cinclusive with respect to the total water budget because subsurface flow is nol included. Values for those flow components are unknown, however they may be similar in magnitude because the known sources of recharge and discharge are similar for the analysis period. Evidence is presented in the conclusion of the "Subsurface Recharge" section that indicates that subsurface recharge is minimal compared to surface recharge. If that is the iase then it is likely that subsurface discharge from the Edwards aquifer is also minimal. Presently, it is likely that surface recharge is in dynamic equilibrium with springflow and pumpage for all but extreme low-flow conditions.

\section{WATER QUALITY}

In order to determine the chemical quality of water in the Edwards aquifer, samples were collected and analyzed from the six major creeks that recharge the aquifer, from 38 wells in the study area, and from Barton Springs. Locations of the surface-water quality sampling sites and ground-water quality sampling sites are shown in figures 28 and 39, respectively. The Edwards aquifer is the waterbearing unit for all wells shown in figure 39, except for wells YD-58-50-409 and LR-58-57-101, which are developed in the upper Trinity aquifer, and YD-58-49-604 which is developed in the middle Trinity aquifer. Technical characteristics and other information for these wells and for other wells and test holes in the study area are presented in table 3.

Analyses for the creeks and Barton Springs include nutrients (ammonia nitrogen, organic nitrogen, nitrite nitrogen, nitrate nitrogen, and phosphorus); physical organic and inorganics (specific conductance, pH, temperature, color, turbidity, dissulved oxygen, suspended and dissolved solids, biochemical-oxygen demand, and total organic carbon); indicator bacteria (total coliform, fecal coliform, and fecal streptococci); inorganic chemical constituents (calcium, magnesium sodiun, potassium, alkalinity, sulfate, chloride, fluoride, and silica); 12 selected trace elements (arsenic, barium, cadmium, chromium, copper, iron, lead, manganese, mercury, selenium, silver, and zinc); 26 insecticides and herbicides; and radiochemical analyses for selected dates and sites.

Analyses for the ground-water samples include all the above constituents except color, turbidity, dissolved oxygen, biochemical-oxygen demand, anil suspended solids. Most ground-water samples must be collected through a punp; thus, the water is subject to high velocity while being collected. This process may alter the values for color, turbidity, and suspended solids. This same collection process may cause dissolved oxygen to be added to the water while the sample is being collected, which would change the values for dissolved oxygen and biochemical-oxygen demand.

Many values for water-quality constituents change with time. Many factors may be responsible for changes in the quality characteristics of water as it is recharged and moves through the aquifer and then discharges as springflow or pumpage. Prucesses such as dilution, sedimentation, absorption, adsorption, chemical precipitation, and die-off of microorganisms can rapidly change concentrations of many constituents. As a given volume of water mixes with other water, the mixed water assumes a quality characteristic that is reflective of both waters. The concentration of some constituents, such as bacterid, are reduced by the cool water temperature of the aquifer. The presence of oxygen in water may significantly change the concentration for many constituents, including the nutrients, biochemical-oxygen demand, and total organic carbon. 


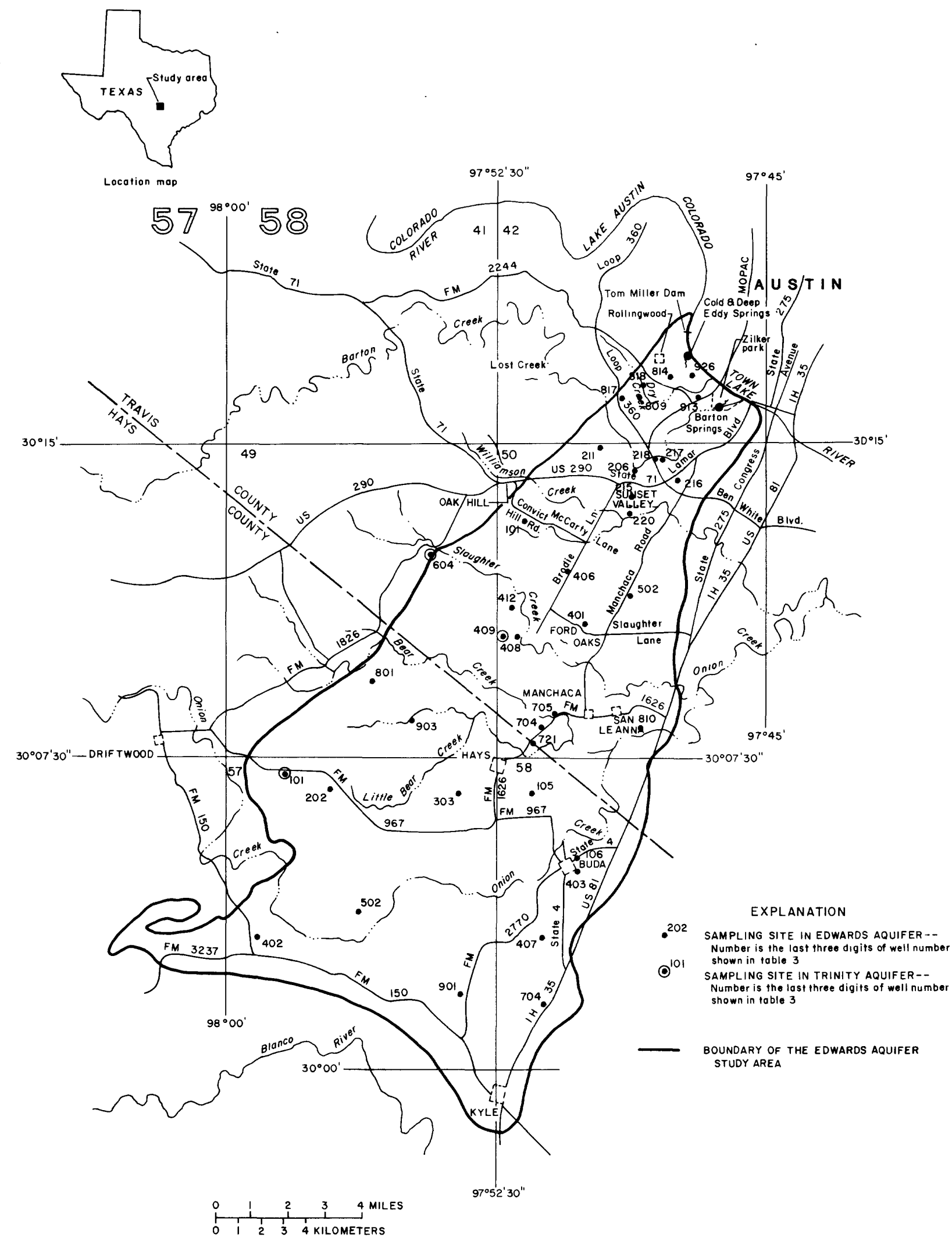

Bose from Texos Department of 
Many of the insecticide and herbicide values also change with time. The inorganic chemical constituents and trace elements identified earlier in this section generally are more stable with respect to chemical changes.

The frequency and peripd of record for water-quality analyses collected and analyzed by the Geological Survey are presented in table 1 . Water-quality data for the six recharge creeks, the wells, and Barton Springs are published in the annual report series by Slade and others $(1980,1981,1982,1983,1984)$ and Gordon and others (1985). Table 7 contains results from selected waterquality analyses for Barton Springs prior to the 1978 initiation of the Geological Survey's current sampling program. From 1975 through September 1983, the Geological Survey operated a water-quality sampling site at Barton Creek immediately downstream from Barton Springs. During times of no flow or low flow in Barton Creek upstream from Barton Springs, all or most of the discharge at the sampling site represented flow from Barton Springs, thus the analyses for many of those samples could be considered representative for Barton Springs.

From August 1981 through September 1982, an intensified water-sampling program was conducted by the Geological Survey. Samples of water from Barton Springs were collected weekly and during storms. Five wells also were sampled during storms. Organic analyses, along with analyses of many of the constituents listed earlier, were included in the water-sampling program. Data collected during this period were the basis of a report concerning effects of storm runoff on water quality for the aquifer study area (Andrews and others, 1984).

Some water-quality data for Barton Springs, other than the data presented in the tables, have been collected and analyzed by agencies other than the Geological Survey. Twidwell (1976) presented bacteria data for Barton Springs. Since about 1980, the Water and Wastewater Department of the City of Austin has collected and analyzed many Barton Springs samples for fecal-coliform and fecalstreptococci bacteria. The Austin-Travis County Health Department has analyzed samples from Barton Springs for a few constituents since about 1980 . That agency also has collected and analyzed samples from near the mouth of Barton Creek. The discharge near the mouth is composed of flow from Barton Springs and, at times, flow from Barton Creek originating upstream from Barton Springs.

The quality of water in the Edwards aquifer generally is very good. Although relatively high concentrations for a few constituents have been detected at a few sites, no regional contamination problems have been identified by this water-quality sampling program. A summary of standards for selected waterquality constituents is presented in table 8 , and the source and significance of selected constituents and properties commoniy reported in water analyses is presented in table 9 (supplemental information). A discussion of selected water-quality constituents for selected sites follows.

\section{Indicator Bacteria}

The ratio of fecal coliform to fecal streptococci for a given sample sometimes is used to help identify the origin of bacterial contamination. Ratios greater than 4 generally indicate contamination predominantly from human sources, while ratios less than 0.7 generally indicate predominantly animal sources. Ratios for the Barton Springs bacteria samples seem to indicate that the source of bacterial contamination varies from human to animal. 


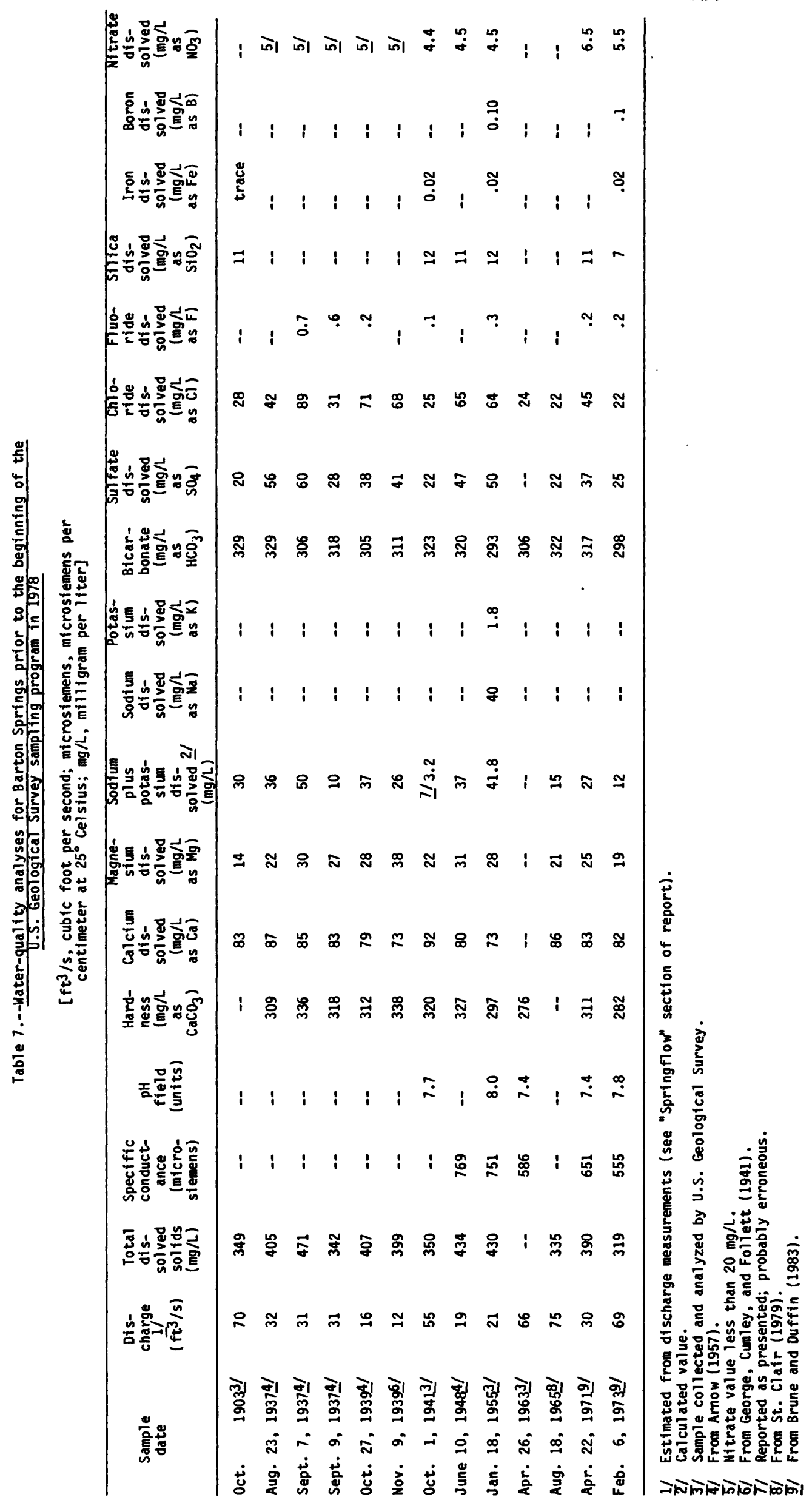


Table 8.--Summary of standards for selected water-quality constituents and properties for public water systems

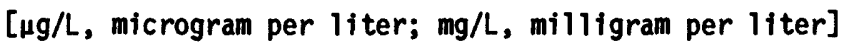

DEFINITIONS

Contaminant.-Any physical, chemical, biological, or radiological substance or matter in water.

Public water system.-A system for the provision of piped water to the public for human consumption, if such system has at least 15 service connections or regularly serves at least 25 individuals daily at least 60 days out of the year.

Maximum contaminant level.- The maximum permissible level of a contaminant in water which is delivered to the free-flowing outlet of the ultimate user of a public water system. Maximum contaminant levels are those levels set by the U.S. Environmental Protection Agency (1976) in the National Interim Primary Drinking Water Regulations. These regulations deal with contaminants that may have a signicant direct impact on the health of the consumer and are enforceable by the Environmental Protection Agency.

Secondary maximum contaminant level.-The advisable maximum level of a contaminant in water which is delivered to the free-flowing outlet of the ultimate user of a public water system. Secondary maximum contaminant levels are those levels proposed by the Environmental Protection Agency (1977a) in the National Secondary Drinking Water Regulations. These regulations deal with contaminants that may not have a significant direct impact on the health of the consumer, but their presence in excessive quantities may affect the esthetic qualities and discourage the use of a drinking-water supply by the public.

\section{INORGANIC CHEMICALS AND RELATED PROPERTIES}

Contaminant
Arsenic (As)
Barium (Ba)
Cadmium (Cd)
Chloride (Cl)
Chromium (Cr)
Copper (Cu)
Iron ( $\mathrm{Fe}$ )
Lead ( $\mathrm{Pb}$ )
Manganese (Mn)
Mercury ( $\mathrm{Hg})$
Nitrate (as $\mathrm{N}$ )
pH
Selenium ( $\mathrm{Se}$ )
Silver ( $\mathrm{Ag})$
Sulfate ( $\mathrm{SO}_{4}$ )
Zinc ( $\mathrm{Zn}$ )
Dissolved solids

Maximum contaminant level

$50 \mu \mathrm{g} / \mathrm{L}$
$1,000 \mu \mathrm{g} / \mathrm{L}$
$10 \mu \mathrm{g} / \mathrm{L}$
--
$50 \mu \mathrm{g} / \mathrm{L}$
--
--
$50 \mu \mathrm{g} / \mathrm{L}$
--
$2 \mu \mathrm{g} / \mathrm{L}$
$10 \mathrm{mg} / 1$
--
$10 \mu \mathrm{g} / \mathrm{L}$
$50 \mu \mathrm{g} / \mathrm{L}$
--
--

Secondary maximum contaminant level

--
--
--
$250 \mathrm{mg} / \mathrm{L}$
$-\overline{-}$
$1,000 \mu \mathrm{g} / \mathrm{L}$
$300 \mu \mathrm{g} / \mathrm{L}$
--
$50 \mu \mathrm{g} / \mathrm{L}$
--
--
$6.5-8.5$
--
--
$250 \mathrm{mg} / \mathrm{L}$
$5,000 \mu \mathrm{g} / \mathrm{L}$
$500 \mathrm{mg} / 1$

Fluoride.-The maximum contamination level for fluoride depends on the annual average of the maximum daily air temperatures for the location in which the community water system is situated. A range of annual averages of maximum daily air temperatures and corresponding maximum contamination level for fluoride are given in the following tabulation.

\section{Average of maximum daily air temperatures} (degrees (elsius)

12.0 and below

$12.1-14.6$

$14.7-17.6$

$17.7-21.4$

$21.5-26.2$

$26.3-32.5$

Maximum contaminant level for fluoride (mg/)
2.4
2.2
2.0
1.8
1.6
1.4

ORGANIC CHEMICALS

Chlorinated hydrocarbons

\begin{tabular}{|c|c|}
\hline Contaminant & $\frac{\text { Maximum contaminant level }}{(\mu \mathrm{g} / \mathrm{L})}$ \\
\hline
\end{tabular}

Endrin

Lindane

Methoxychlor

Toxaphene
0.2

4

100

\section{Chlorophenoxys}

Contaminant Maximum contaminant level (ug/L)

2,4-D

Silvex

100 
Fecal-coliform bacteria has been the only constituent from Barton Springs that at times has exceeded established water-quality criteria. No criteria levels exist for fecal streptococci, but the Texas Surface-Water Quality Standards as specified by the Texas Department of Water Resources (1981), state that surface waters suitable for contact recreation shall not exceed a mean fecal-coliform density of 200 cols./100 mL (colonies per 100 milliliters). Several samples have exceeded that density, and with only one exception, all of these samples were collected within 3 days after a day of precipitation. Runoff from precipitation probably transmits bacteria from surface sources or leaking sewer lines into the aquifer as recharge close to Barton Springs, where it discharges with springflow. The fecal-coliform density for each sample and the number of days prior to the sample-collection date that have elapsed since the previous day of precipitation are shown in figure 40 . Many samples were taken on a day when precipitation occurred, and those points are indicated as zero days since previous precipitation.

The recharge creeks also contain high densities of bacteria. Fecal-coliform and fecal-streptococci densities in Barton Creek, Williamson Creek, and Slaughter Creek upstream from the recharge zone have been as great as 100,000 cols./100 mL, and bacteria densities almost as high also have been found in Bear and Onion Creeks. Bacteria, as previously mentioned, are nonconservative with respect to time and are rapidly reduced by the relatively cool temperature of water. Because the attrition rate for bacteria is very high, the densities in the recharge water are reduced significantly before that water is discharged at Barton Springs. High bacteria densities have been measured in the recharge creeks, however, samples from wells and Barton Springs contain much lower densities of bacteria.

Densities of fecal coliform exceeding 200 cols./100 mL were found in 3 of the 38 wells sampled, and densities of fecal streptococci exceeding 200 cols./ $\mathrm{mL}$ were found in 12 wells. Livestock, which are abundant in parts of the study area, probably are the major source for fecal streptococci. Because fecal densities in water samples from the Edwards aquifer are low and diminish with time-of-travel, it is evident that the sources of this bacteria, when found in water from Barton Springs, are near the springs.

The source for at least some of the high fecal-coliform densities for Barton Springs is probably any of several sewer lines near the springs. The city of Austin owns and maintains sewer lines in the immediate proximity of Barton Springs, any one of which, if leakage occurred, could contaminate the springs. William F. Guyton and Associates (1964) reported to the city of Austin about the possible effects of a proposed sewer line upon the water quality of Barton Springs. That report made several recommendations concerning method of installation, location, and maintenance for sewer lines in the proximity of the springs, and stated that, "Leakage from a sewer into the Edwards Reservoir would be a potential source of contamination of the spring water. The degree of danger of contamination from leakage would vary depending upon the location of the leakage and its distance from the springs." In April 1982, personnel from the Water and Waste Water Department of the City of Austin injected dye into one of the sewers near Barton Springs. The dye was later detected discharging from the springs. The leaking sewer line was repaired and subsequent bacteria counts have been reduced but because there are many sewer lines near the springs, fecal-coliform contamination of the springs may be a recurring problem. 


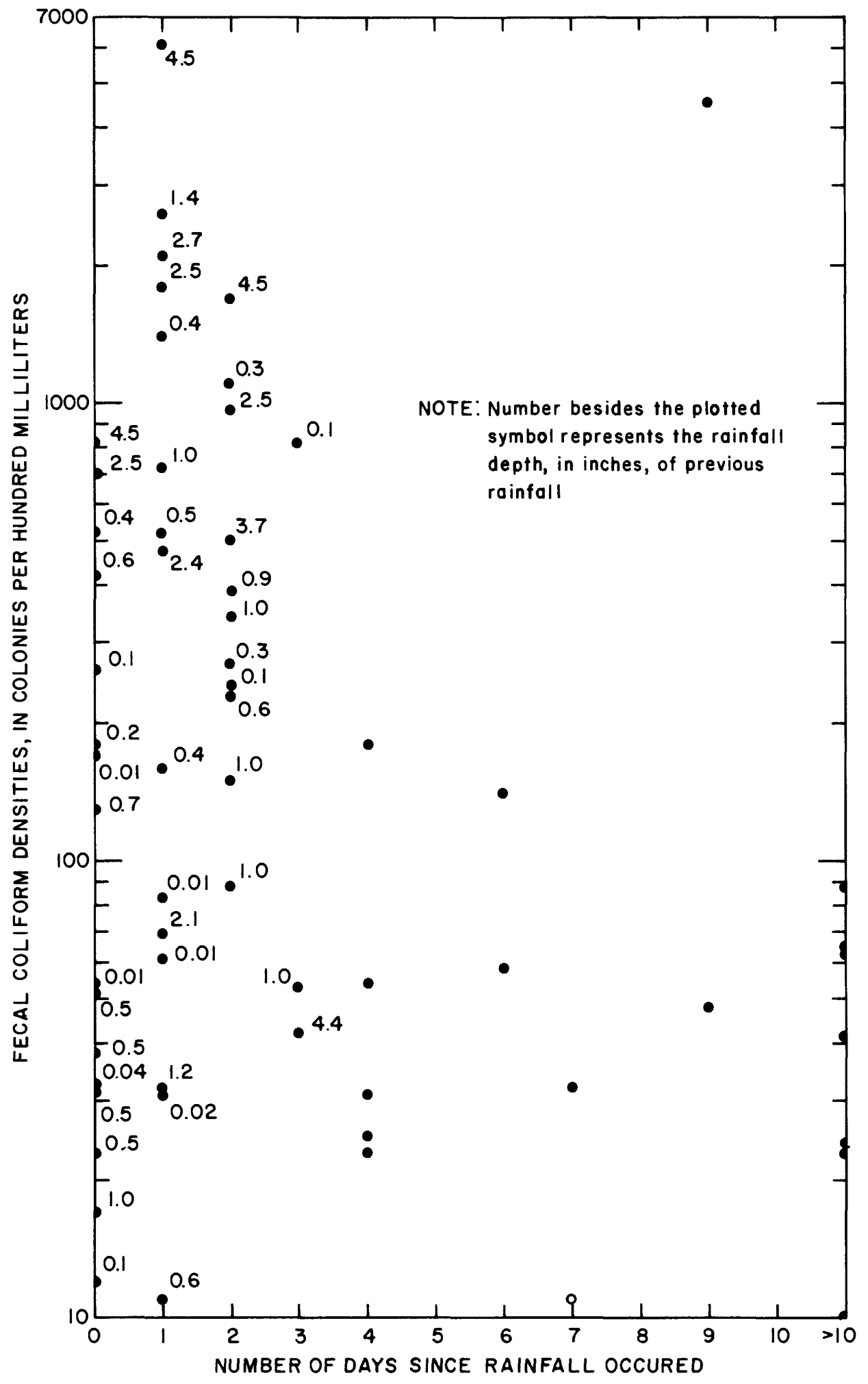

Figure 40.--Fecal-coliform values with respect to precipitation for water-quality samples from Barton Springs. 


\section{Nitrate Nitrogen}

The Texas Department of Health and the U.S. Environmental Protection Agency have established a common maximum level of $10 \mathrm{mg} / \mathrm{L}$ for nitrate nitrogen in drinking water in public water systems. The significance and source of nitrate nitrogen is discussed in table 9. Three samples of Barton Springs water collected from 1941-55 had nitrate nitrogen concentrations of about 1.0 $\mathrm{mg} / \mathrm{L}$. On the basis of the latest samples from the springs, concentrations of this constituent have remained fairly consistent at about $1.5 \mathrm{mg} / \mathrm{L}$. Almost all samples from the recharge creeks had nitrate nitrogen concentrations less than $1.0 \mathrm{mg} / \mathrm{L}$. Al though these values for the springs and recharge creeks are well within established water-quality criteria, some relatively high concentrations have been noted in specific wells in the aquifer.

The highest nitrate-nitrogen concentrations from wells measured in the Geological Survey's current sampling program are shown in figure 41 , along with values for this constituent as reported by Brune and Duffin (1983), DeCook (1960), and DeCook and Doyel (1955). The values from the Geological Survey's program are from analyses of samples collected between 1978 and 1982 . The remainder of the data are from analyses of samples collected from 1937-73 with most of these samples being taken between 1969 and 1973. Because the volume of recharge and water levels within the aquifer vary considerably, values for these and many other constituents probably will vary with respect to hydrologic conditions.

The highest concentrations of nitrate nitrogen have been found in wells west of Buda, west of Kyle, just north of Williamson Creek, and between Williamson and Slaughter Creeks (fig. 41). The general direction of ground-water movement as indicated by a potentiometric-surface map of the Edwards aquifer (fig. 19) indicates that the relatively high levels of nitrate nitrogen between Williamson Creek and Slaughter Creek probably came from sources along Slaughter Creek. Cattle and septic-tank or sanitary-sewer systems in residential developments west of the areas are the probable source for the elevated counts. Also, there are a few privately owned sewage-treatment plants which have permits from the Texas Water Commission to discharge wastewater into creeks crossing the recharge area. These plants may be a source of high nitrate nitrogen. All of the samples having high concentrations of nitrate nitrogen were collected from relatively shallow wells in the Edwards aquifer. Deeper wells generally contain water having relatively low concentrations of this constituent.

Generally, the highest levels of bacteria and nitrate nitrogen have been found in the recharge area of the aquifer, in wells near creeks. Runoff probably transports these constitutents from source areas of animal and human feces to the creeks where it enters the aquifer with recharge water. Andrews and others (1984) concluded that bacteria and nitrate nitrogen in several wells varied significantly in response to changes in the quantity of recharge. A few land developments in the area have used evapotranspiration systems involving irrigation of sewage and runoff from urbanized lands as a method of minimizing the amount of urban runoff in streams. Large volumes of this irrigation have been possible because of high rates of evapotranspiration in the area ("Surface Recharge" section). 


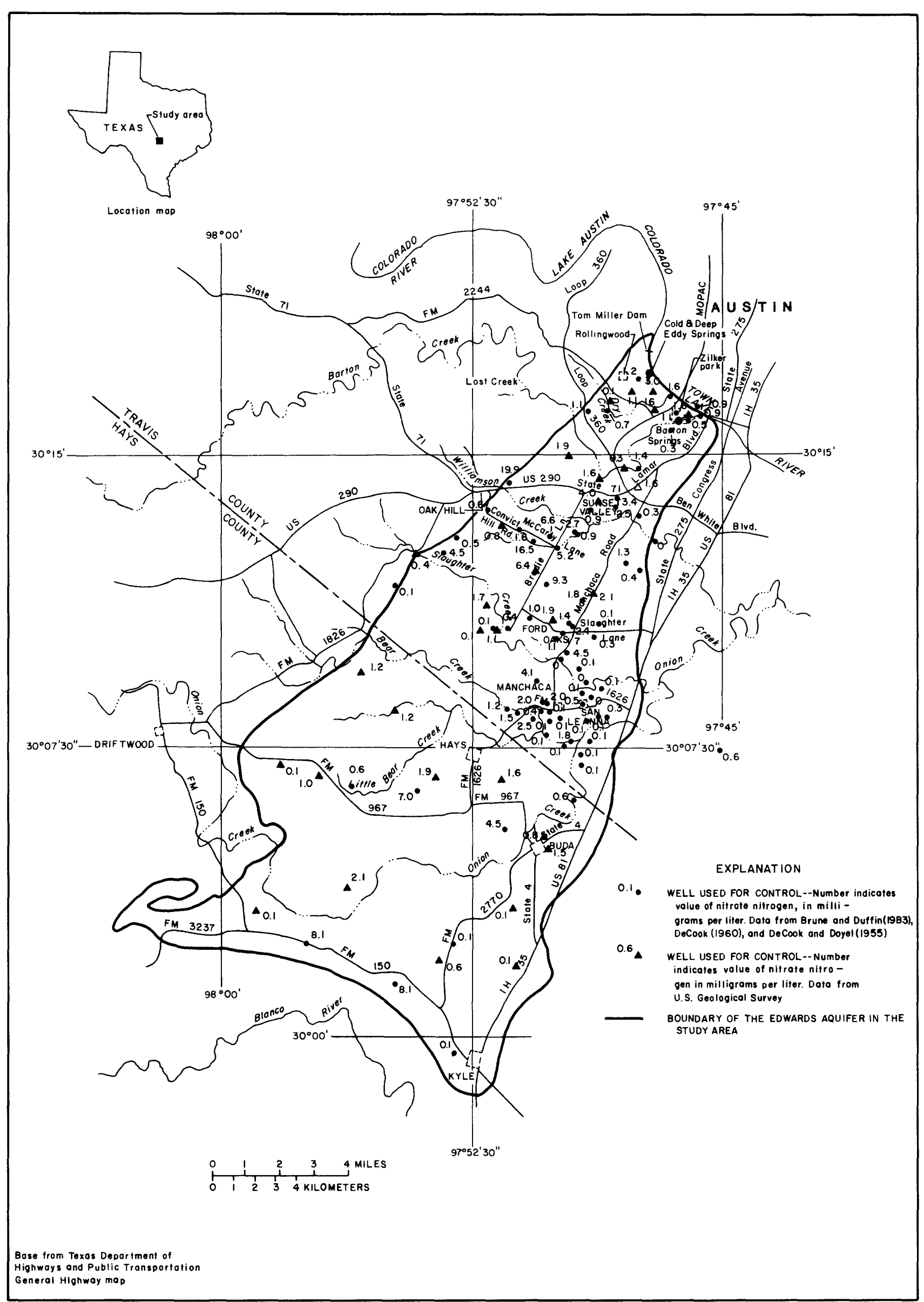

Figure 41.--Nitrate nitrogen values for wells developed in the Edwards aquifer. 
The significance and source of fluoride and the maximum contaminant level for fluoride are discussed in tables 8 and 9. The average of maximum daily air temperatures of Austin, Texas, upon which the maximum contaminant level for this area is based, is $78.8^{\circ} \mathrm{F}$ for $1941-70$. Thus, according to table $8,1.6$ $\mathrm{mg} / \mathrm{L}$ is the maximum contaminant level of this constituent for a public water system. Fluoride concentrations for water from Barton Springs and for streamflow in the six recharge creeks have been well below this level; however, three wells within the Geological Survey's current sampling program have produced water with fluoride concentrations that have exceeded this level. Wells YD-58-50-810, LR-58-58-407, and LR-58-58-704 have produced water with maximum fluoride concentrations of $2.3,1.8$, and $3.9 \mathrm{mg} / \mathrm{L}$, respectively.

Fluoride: concentrations from the Geological Survey's current sampling program are shown in figure 42, along with those values reported by Brune and Duffin (1983) and DeCook (1960). As this illustration shows, the higher concentrations of fluoride are in the eastern part of the aquifer. High levels of fluoride also can be found in wells developed in the Trinity aquifer. Water from most wells in the Edwards aquifer having a relatively high fluoride concentration also has inorganic chemical characteristics similar to water from the upper Trinity aquifer. Because of this, the probable source for the high concentrations of fluoride is the upper Trinity aquifer.

\section{Relation of Water Quality of Barton Creek to Water Quality of Barton Springs}

Barton Creek, which drains an area of about $125 \mathrm{mi}^{2}$, contributes approximately 28 percent of the long-term recharge to the part of the Edwards aquifer discharging to Barton Springs. The downstream end of the recharge reach of Barton Creek is near Barton Springs; consequently, the quality of water at the springs responds rapidly to changes in quality of recharge contributed by the creek.

Ground water originating from Barton Creek remains in the aquifer for only a short period before discharging at Barton Springs; thus processes such as absorption, adsorption, and chemical precipitation have relatively little time to decrease concentrations of water-quality constituents of that water. Because of the amount and proximity of recharge contributed by Barton Creek, this creek has a greater impact upon the quality of Barton Springs than any other recharge source.

Land use in the drainage area in and upstream from the recharge area is predominantly a rural-urban mix. The quantity and quality of streamflow that originates in this drainage area are measured at the gaging station 08155300 Barton Creek at Loop 360 (fig. 28). Water samples are collected periodically by an automatic sampler at this site during storm runoff. Water-quality data for this site provide background information on the quality of recharge to the Edwards aqui rer from Barton Creek.

Changes in turbidity of Barton Springs water after a storm show how rapidly recharge water, with its relatively high turbidity, moves through the aquifer to discharge at Barton Springs. Personnel at Barton Springs swimming pool have 


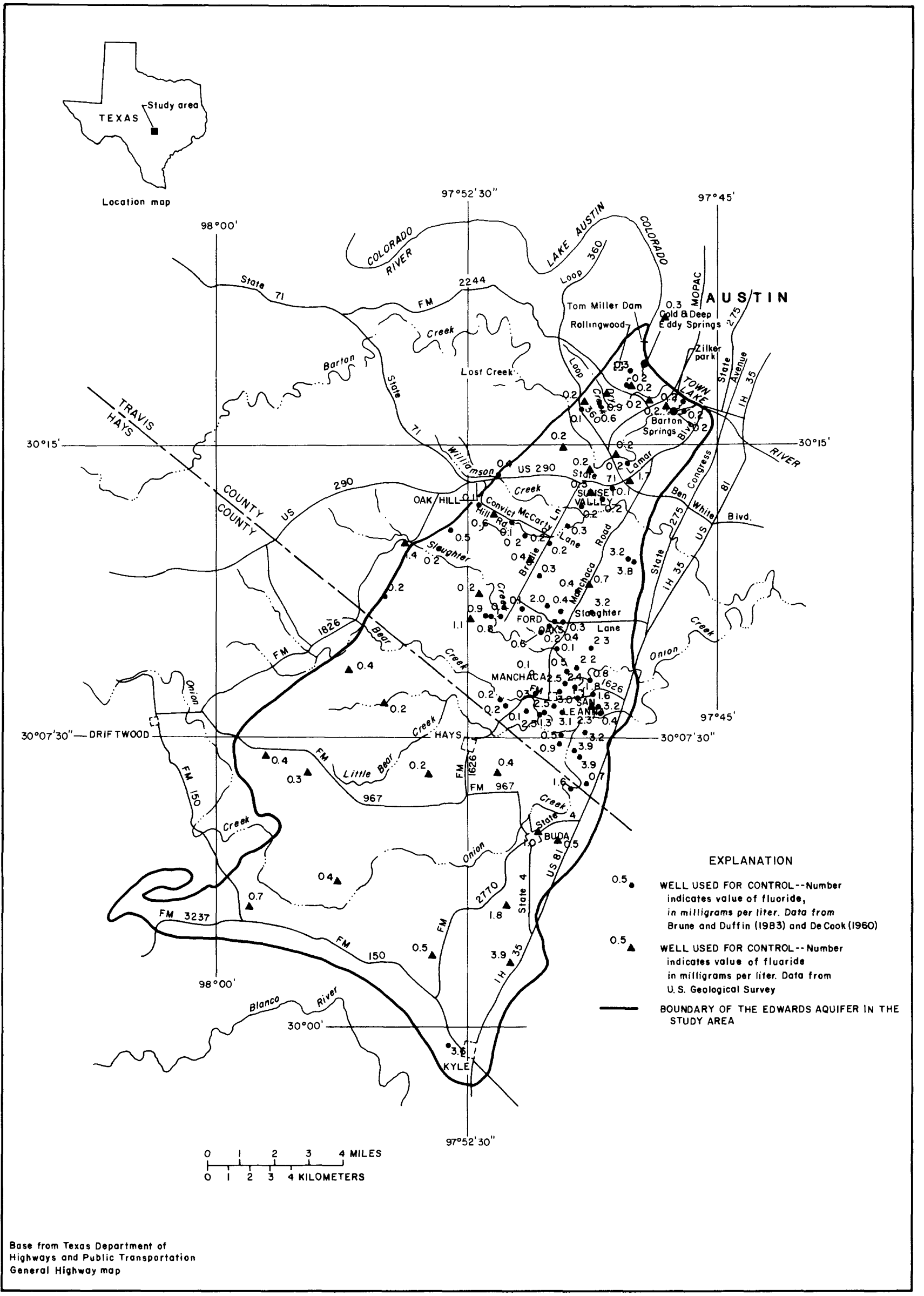

Figure 42.--Fluoride values for wells developed in the Edwards aquifer. 
been collecting and analyzing samples of water from the springs for turbidity since 1980. In the case of water from Barton Springs, high turbidity indicates high concentrations of suspended clay and silt which do not necessarily indicate a health hazard.

Turbidity readings of Barton Springs water for May 8-9, 1980, are presented in figure 43. Also shown in this illustration are precipitation and discharge data for Barton Creek at Loop 360 for that same period. Much construction activity was occurring in the Barton Creek watershed at the time of the storm. Construction activity in 1981 and 1982 was less than in 1980, and turbidity of Barton Springs water was correspondingly less. All high values for turbidity have occurred immediately following precipitation, although high values do not occur after every storm. When high turbidity does occur, officials must close Barton Springs pool to swimmers until turbidity recedes to acceptable levels, usually about a day as figure 43 shows. The source of the clay and silt in the turbid waters probably is in the Barton Creek watershed. Any silt or clay that is subject to being washed into Barton Creek during storms is incorporated into the recharge water and may be discharged from Barton Springs. Construction activities generally "unearth" and expose much new ground, so as construction activities continue in the Barton Creek watershed, Barton Springs may continue to occasionally experience short periods of high turbidity.

Specific-conductance measurements of water samples for Barton Creek at Loop 360 and Barton Springs also provide information regarding the rapid movement of recharge water to discharge from Barton Springs. Specific conductance is a measure of the ability of a water to conduct an electrical current and is related to the types and concentrations of ions in solution. The specific conductance of a solution increases as the ionic concentration increases. Consequently, the measurement of this constituent is useful as a general indication of the dissolved-solids concentration of a water sample and can be used to indicate variations in mineralization.

Specific conductances for samples from Barton Creek at Loop 360 and Barton Springs for May 13-17, 1982, are presented in figure 44. Also shown in the illustration are the discharges for those two sites during that period. A comparison of these data indicates that the streamflow from the May 13, 1982, storm was less mineralized than ground water discharged by Barton Springs. As water from storm runoff recharged and moved through the Edwards aquifer, a decrease in the mineralization of water from Barton Springs occurred. As storm runoff ceased, the rate of recharge decreased and the mineralization of Barton Springs water increased. Thereafter, as the rate of recharge decreased and as the recharge water was dispersed through the aquifer, the mineralization of the ground water gradually increased in response to the increased mineralization of the "older" water in the aquifer.

\section{NEED FOR MONITORING AND FUTURE STUDIES}

Collection of data concerning the quantity and quality of surface recharge water, as well as the quantity and quality of water discharged from Barton Springs, is continuing. However, data-collection activities involving groundwater levels and ground-water quality were discontinued October 1, 1983. In 1985, the Geological Survey and city of Austin began a ground-water quality monitoring program involving 15 of the wells sampled by the Geological Survey 


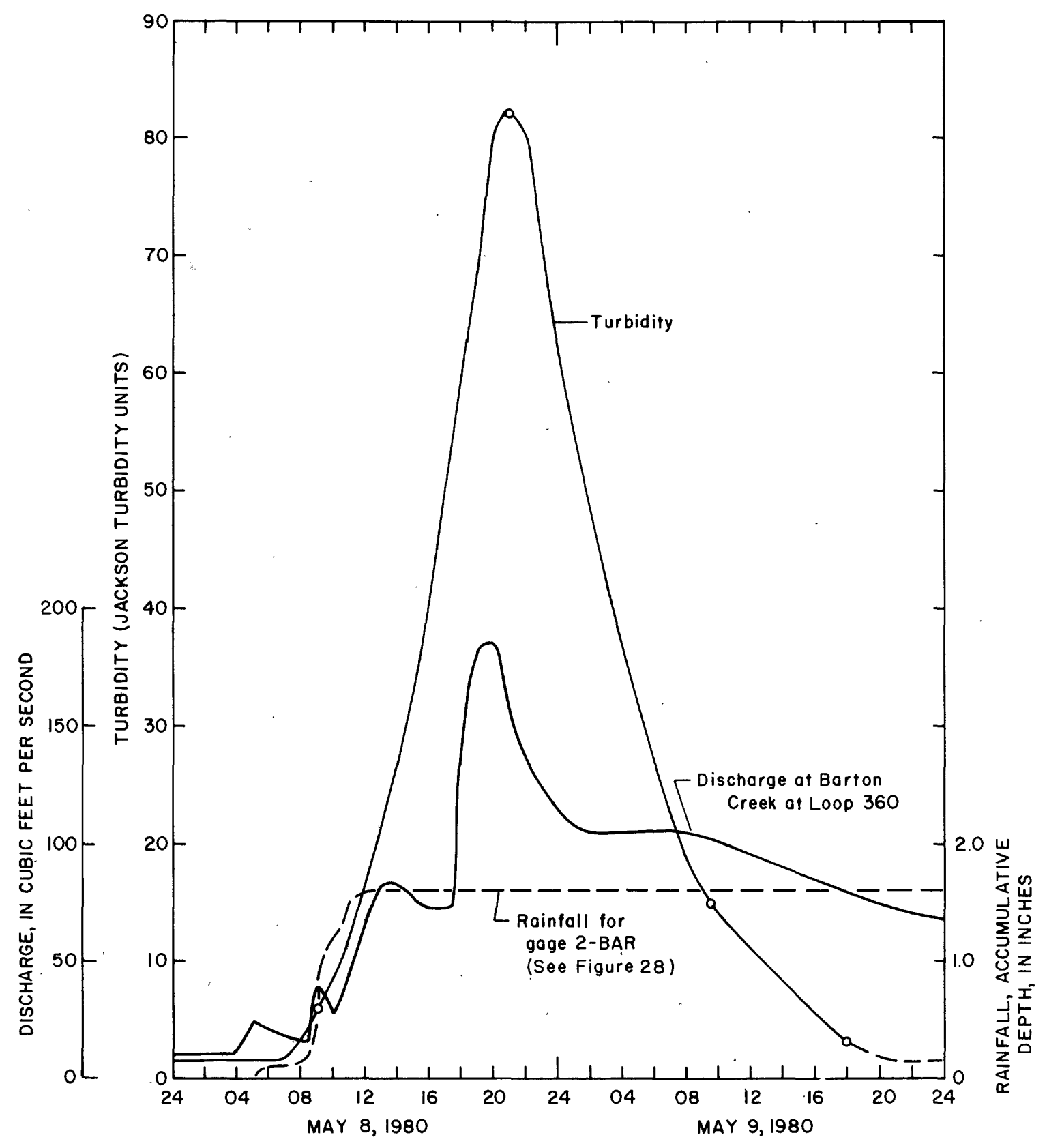

Figure 43.--Turbidity of Barton Springs water following storm of May 8, 1980. 


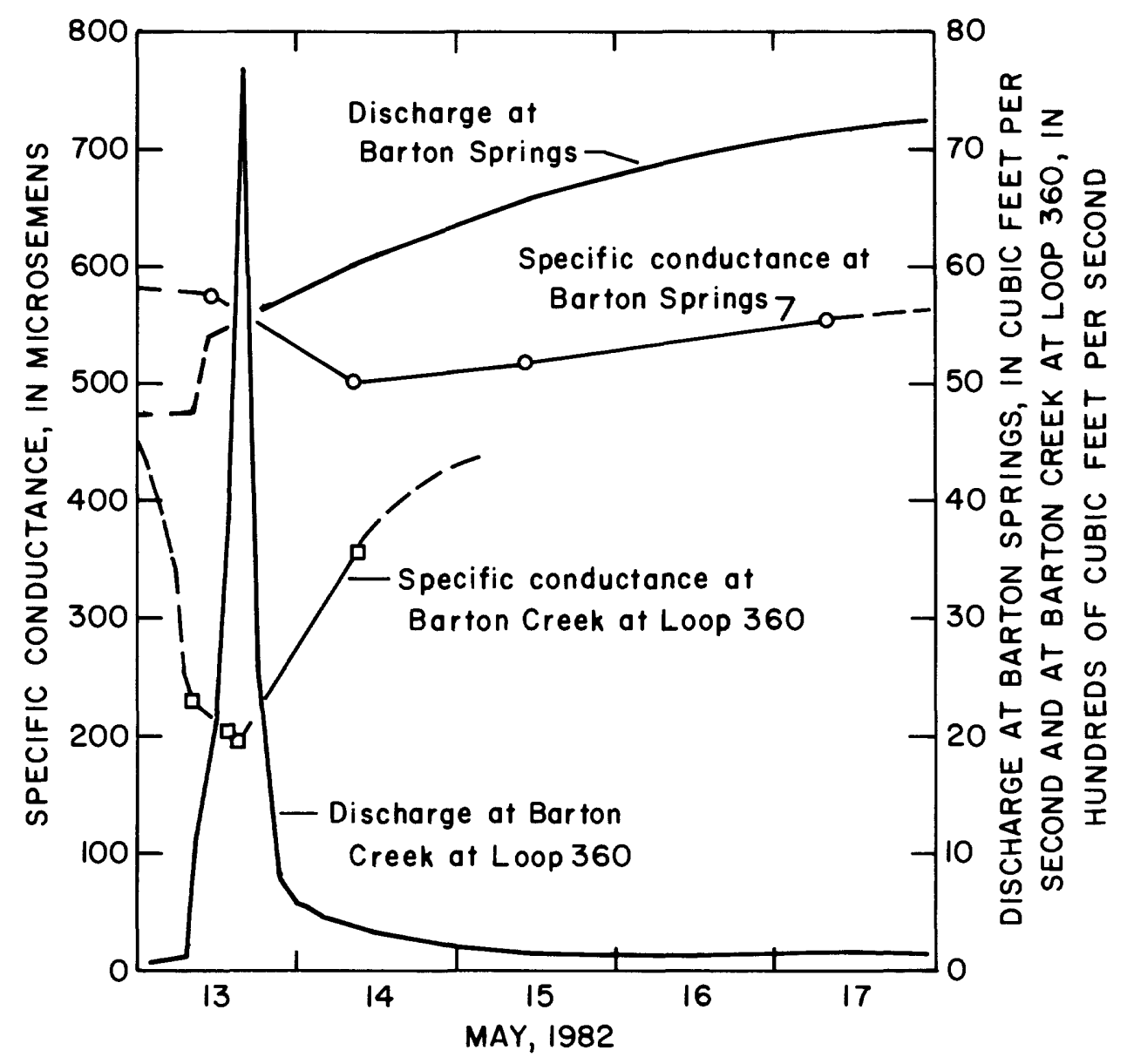

Figure 44.--Relation of specific conductance and discharge of water from Barton Springs to specific conductance and discharge of Barton Creek. 
from 1978 to 1983. Except for that program and a limited ongoing program involving water-level measurements at selected wells conducted by the Texas Department of Water Resources, the Geological Survey completed the only groundwater monitoring program in the study area.

Much of the land within the relatively small study area is being developed rapidly, and, thus, the ground-water resources of the aquifer may change accordingly. The available data are adequate to define the ground-water resources under present conditions and make certain conclusions. However, the continued collection of specific ground-water data could greatly enhance the understanding of ground-water avalablility and quality during future development conditions.

As the Edwards aquifer is further developed with wells, the amount of depletion associated with this pumpage could be monitored by making water-level measurements at selected observation wells throughout the study area. Rela-. tively high concentrations of nitrate nitrogen and fecal bacteria have been found in selected wells in the Edwards aquifer; and as further development occurs in the aquifer area, the concentrations of these and other water-quality constituents may increase. A continuing ground-water quality-sampling program would provide information on the impact of future development on water quality of the Edwards aquifer.

Studies that could provide added understanding of the ground-water resources of the Edwards aquifer include:

1. Ground water in the aquifer generally is of better quality than the streamflow which provides surface recharge. A study of the effects of the unsaturated zone of the aquifer an the quality of water as it moves through that zone to the water table could be a useful planning and management tool. In 1984, the Geological Survey in cooperation with the city of Austin began a study of the effects of the unsaturated zone of the Edwards aquifer on the attenuation of contaminants. This study should provide some information on the attenuation of contaminants in the unsaturated zone.

2. A study of the effects of various types of sewage treatment (septic systems, package-treatment plants, irrigational systems, and evapotranspiration systems) upon the quality of water in the Edwards aquifer would provide useful information for managing the water quality of the aquifer.

3. As discussed in the "Pumpage" section of this report, only a few of the major well fields have a metering system for determining pumpage volume, so the total amount of pumpage is estimated and the accuracy cannot be verified. A program that would inventory and verify the number of wells and the amount of pumpage could be beneficial in determining the extent of ground-water use. An accurate accounting of this use would be needed before projections concerning the total available resources of the aquifer can be made.

4. A study of the extent and amount of subsurface leakage from the Trinity aquifers into the Edwards aquifer as the Edwards aquifer is further developed with wells would provide information for predicting future ground-water levels.

5. A study of the extent and amount of bad-water encroachment into the Edwards aquifer as the aquifer is further developed with wells would provide information for predicting future water quality of the aquifer.

6. A study of the effects of high rates of pumpage on a ground-water divide that approximates the southern boundary for the aquifer study area would help identify flow patterns and directions in this area. 


\section{SUMMARY OF CONCLUSIONS}

1. The Edwards aquifer in the study area underlies an area of $155 \mathrm{mi}^{2}$ of which about $151 \mathrm{mi}^{2}$ discharge to Barton Springs and the remaining $4 \mathrm{mi}^{2}$ discharge into Cold and Deep Eddy Springs. The westernmost $90 \mathrm{mi}^{2}$ of the aquifer area comprise the recharge area. The aquifer varies in thickness from about $100 \mathrm{ft}$, where it crops out within the recharge area, to about 400 to 450 $\mathrm{ft}$ in the confined area.

2. The unconfined part of the aquifer occupies the westernmost 79 percent of the aquifer, and the remaining easterly part is under confined conditions. Water levels change rapidly and are highly correlated throughout most of the aquifer, a characteristic indicative of a confined aquifer. The mean specific yield of the transient part of the unconfined portion of the aquifer is 0.017 . The storage coefficient for the confined part ranges from $3 \times 10^{-5}$ to $6 \times 10^{-5}$. Total storage within the aquifer is about 306,000 acre- $\mathrm{ft}$, of which about 31,000 acre-ft is the change in storage occurring between high flow and the lowest known flow of Barton Springs. Storage and movement of ground water are predominantly by means of dissolution cavities, and well yields throughout the aquifer or even in short distances may vary by several orders of magnitude.

3. Most of the total recharge to the aquifer occurs from surface water entering the aquifer along faults within the recharge area. About 85 percent of the surface-water recharge occurs along the main channels of six creeks that cross the recharge area, and the remaining 15 percent occurs in the areas between the main channels of the creeks within the recharge area. Total surface recharge varies from almost 0 to about $350 \mathrm{ft} 3 / \mathrm{s}$. When the ground-water levels are low, ground water from the bad-water zone encroaches into the freshwater part of the aquifer, mixes with the fresh water, and discharges from Barton Springs. Near faults, subsurface leakage into the Edwards aquifer from the underlying Trinity aquifers can be observed at specific wells. There is evidence that subsurface recharge to the study area occurred from the Edwards aquifer to the south during a severe drought in 1954-56.

4. Barton Springs has a long-term mean discharge of $50 \mathrm{ft}^{3} / \mathrm{s}$ and a minimum and maximum discharge of 10 and $166 \mathrm{ft}^{3} / \mathrm{s}$. In 1982, pumpage from the aquifer averaged just over $5 \mathrm{ft}^{3} / \mathrm{s}$, which is about 10 percent of the aquifer's long-term mean discharge. Increased pumpage associated with future ground-water development could reduce the discharge at Barton Springs and reduce the overall availability of ground water. Substantial pumpage increases could cause more highly mineralized water from the bad-water zone to encroach into the aquifer's freshwater system, which could cause at least part of the flow from Barton Springs to originate from the bad-water zone. Substantial pumpage could also cause an increase in the amount and areal extent of leakage from the Trinity aquifers into the Edwards aquifer. Recharge volumes could be increased significantly by impounding flood runoff and releasing that water through outlets so that it may recharge the aquifer.

5. The quality of water in the aquifer and from Barton Springs generally is better than the quality of the creeks that recharge the aquifer. The only known constituent presenting a water-quality problem at Barton Springs has been fecal-group bacteria. Nitrate nitrogen, fecal-group bacteria, and fluoride have been the only constituents that represent ground-water contamination problems. Of the 38 wells sampled, densities of fecal bacteria exceeding 200 cols./100 mL were found in 12 wells. The source of the nitrate nitrogen and fecal-group bacteria probably is human and animal feces. Nitrate nitrogen and fecal-bacteria levels of the ground water may increase from sewage generated by 
future development of lands within the recharge or adjoining areas that contribute runoff to the recharge area. The high fluoride concentrations probably originate from leakage into the Edwards aquifer from the upper Trinity aquifer. 6. Surface recharge from Barton Creek has a significant impact upon Barton Springs, and the quality of water from Barton Springs is more sensitive to the quality of streamflow in Barton Creek than from any other surface recharge source. 


\section{SELECTED REFERENCES}

Abbott, P. L., 1975, On the hydrology of the Edwards Limestone, south-central Texas: Journal of Hydrology, v. 24 p. 251-269.

1976, Effect of Balcones faults on groundwater movement, South-Central Texas: Texas Journal of Science, v. 29, p. 5-14.

American Geological Institute, 1980, Glossary of geology (2d ed.): Falls Church, Virginia, $749 \mathrm{p}$.

American Public Health Association and others, 1975, Standard methods for the examination of water and wastewater (14th ed.): Washington, D.C., American Public Heal th Association, 1193 p.

Andrews, F. L., Schertz, T. L., S1 ade, R. M., Jr., and Rawson, Jack, 1984, Effects of storm-water runoff on water quality of the Edwards aquifer near Austin, Texas: U.S. Geological Survey Water-Resources Investigations Report 84-4124, $50 \mathrm{p}$.

Arnow, Ted, 1957, Records of wells in Travis County, Texas: Texas Board of Water Engineers Bulletin 5708, 32 p.

Ashworth, J. B., 1983, Ground-water availability of the lower Cretaceous formations in the Hill Country of south-central Texas: Texas Department of Water Resources Report 273, 172 p.

Baker, E. T., Jr., Slade, R. M., Jr., Dorsey, M. E., Ruiz, L. M., and Duffin, G. L., 1986, Geohydrology of the Edwards aquifer in the Austin area, Texas: Texas Water Development Board Report 293, 217 p.

Baker, E. T., Jr., and Watson, J. A., 1974, Quantity of low flow in Barton Creek, Texas, July 6-8, and OCtober 1-3, 1970: U.S. Geological Survey Open-File Report, 26 p.

Baldwin, H. L., and McGuinness, C. L., 1963, A primer on ground water: U.S. Geological Survey, $26 \mathrm{p}$.

Barnes, B. A., 1938, Records of wells and springs, drillers' logs, water analyses, and map showing location of wells in Hays County, Texas: Texas Board of Water Engineers duplicate report, 31 p.

Brune, Gunnar, 1975, Major and historical springs of Texas: Texas Water Deve1opment Board Report 189, 94 p.

-.---, 1981, Springs of Texas, v. 1: Fort Worth, Branch-Smith Inc., 566 p.

Brune, Gunnar, and Duffin, G. L., 1983, Occurrence, availability, and qual ity of ground water in Travis County, Texas: Texas Department of Water Resources Report 276, 219 p.

DeCook, K. J., 1960, Geology and ground-water resources of Hays County, Texas: Texas Board of Water Engineers Bulletin 6004, $170 \mathrm{p}$.

-.--, 1963, Geology and ground-water resources of Hays County, Texas: U.S. Geological Survey Water-Supply Paper 1612,72 p.

DeCook, K. J., and Doyel, W. W., 1955, Records of wells in Hays County, Texas: Texas Board of Water Engineers Bulletin 5501, 63 p.

Espey, Huston and Associates, Inc., 1979, A study of some effects of urbanization on the Barton Creek watershed: Austin, report prepared by Espey, Huston and Associates and R. W. Harden and Associates for City of Austin.

Follett, C. R., 1956, Records of water-level measurements in Hays, Travis, and Williamson Counties, Texas, 1937 to May 1956: Texas Board of Water Engineers Bulletin 5612, $74 \mathrm{p}$.

Garner, L. E., and Young, K. P., 1976, Environmental geology of the Austin area; An aid to urban planning: Austin, University of Texas, Bureau of Economic Geology Report of Investigations 86, $39 \mathrm{p}$. 
Garza, Sergio, 1962, Recharge, discharge, and changes in ground-water storage in the Edwards and associated limestones, San Antonio area, Texas, a progress report on studies, 1955-59: Texas Board of Water Engineers Bulletin $6201,51 \mathrm{p}$.

George, W. O., Cumley, J. C., and Follett, C. R., 1941, Records of wells and springs, drillersi logs, water analyses, and map showing locations of wells and springs in Travis County, Texas: Texas Board of Water Engineers duplicate report, $101 \mathrm{p}$.

Gordon, J. D., Pate, D. L., and Dorsey, M. E., 1985, Hydrologic data for urban studies in the Austin, Texas, metropolitan area, 1983: U.S. Geological Survey Open-File Report 85-172, 154 p.

W. F. Guyton and Associates, 1958, Recharge to the Edwards reservoir between Kyle and Austin: Austin, 5 p.

---.-, 1964, Barton Springs and associated ground-water conditions, with particular reference to possible effects of a proposed sewer line in the Barton Creek area: Austin, report to the City of Austin, $17 \mathrm{p}$.

Hem, J. D., 1970, Study and interpretation of the chemical characteristics of natural water (2d ed.): U.S. Geological Survey Water-Supply Paper 1473, $363 \mathrm{p}$.

Jacob, C. E., 1950, Flow of ground water, chapter 5 in Rouse, Hunter (ed.), Engineering hydraulics: New York, John Wiley and Sons.

Klemt, W. B., Perkins, R. D., and Alvarez, H. J., 1975, Ground-water resources of part of central Texas with emphasis on the Antlers and Travis Peak Formations: Texas Water Development Board Report 195, v. 1, 63 p.; v. 2, $528 \mathrm{p}$.

Langbein, W. B., and Iseri, K. T., 1960, General introduction and hydrologic definitions: U.S. Geological Survey Water-Supply Paper 1541-A, 29 p.

Lohman, S. W., 1972, Ground-water hydraulics: U.S. Geological Survey Professional Paper $708,70 \mathrm{p}$.

Maclay, R. W., Rettman, P. L., and Smal1, T. A., 1980, Hydrochemical data for the Edwards aquifer in the San Antonio area, Texas: Texas Department of Water Resources LP-131, $38 \mathrm{p}$.

Maclay, R. W., and Small, T. A., 1984, Carbonate geology and hydrology of the Edwards aquifer in the San Antonio area, Texas: U.S. Geological Survey Open-File Report 83-537, $72 \mathrm{p}$.

Marek, E. A., 1981, Water, water conservation, and the Edwards aquifer: San Marcos, Texas, Southwest Texas State University, Edwards Aquifer Research and Data Center, $34 \mathrm{p}$.

McKee, J. E., and Wolf, H. W., 1963, Water quality criteria (2d ed.): California State Water Quality Board Publication 3-A, 548 p.

Monroe, W. H., 1970, A glossary of karst terminology: U.S. Geological Survey Water-Supply Paper 1899-K, 26 p.

National Academy of Sciences, National Academy of Engineering, 1973 [1974], Water quality criteria, 1972: Washington, D.C., Report to the Committee on Water Quality Criteria, 594 p.

National Technical Advisory Committee to the Secretary of the Interior, 1968, Water quality criteria: Washington, D.C., U.S. Government Printing Office, 234 p.

Petitt, B. M., Jr., and George, W. 0., 1956, Ground-water resources of the San Antonio area, Texas: Texas Board of Water Engineers Bulletin 5608, v. 1, $80 \mathrm{p}$.

Prezbindowski, D. R., 1981, Burial diagenesis, Edwards Formation, Lower Cretaceous, south-central Texas: Austin, University of Texas, unpublished Ph.D. dissertation, $237 \mathrm{p}$. 
Rodda, P. U., Garner, L. E., and Dawe, G. L., 1970, Geologic quadrangle map 38, Austin West, Travis County, Texas: Austin, University of Texas, Bureau of Economic Geology, scale $1: 24,000,11 \mathrm{p}$.

Rose, P. R., 1972, Edwards Group, surface and subsurface, central Texas: Austin, University of Texas, Bureau of Economic Geology Report of Investigations 74, $198 \mathrm{p}$.

Rugen, M. A., Lewis, D. A., and Benedict, I. J., 1977, Evapotranspiration--A method of disposing of septic tank effluent: Report No. G7-185, Edwards Underground Water District, $83 \mathrm{p}$. (plus appendices).

Ruiz, Linda, 1985, A benefit cost analysis of the proposed recharge lake on Onion Creek near Austin, Texas: Austin, University of Texas, unpublished Professional Report, 70 p.

Senger, Rainer, 1983, Hydrogeology of Barton Springs, Austin, Texas: Austin, University of Texas, unpublished M.S. thesis, $120 \mathrm{p}$.

Slade, R. M., Jr., Dorsey, M. E., Gordon, J. D., and Mitche11, R. N., 1980, Hydrologic data for urban studies in the Austin, Texas, metropolitan area, 1978: U.S. Geological Survey Open-File Report 80-728, 229 p.

Slade, R. M., Jr., Dorsey, M. E., Gordon, J. D., Mitchel1, R. N., and Gaylord, J. L., 1981, Hydrologic data for urban studies in the Austin, Texas, metropolitan area, 1979: U.S. Geological Survey Open-File Report 81-628, 281 p.

Slade, R. M., Jr., Gaylord, J. L., Dorsey, M. E., Mitchell, R. N., and Gordon, J. D., 1982, Hydrologic data for urban studies in the Austin, Texas, metropolitan area, 1980: U.S. Geological Survey Open-File Report 82-506, $264 \mathrm{p}$.

Slade, R. M., Jr., Ruiz, Linda, and Slagle, Diana, 1985, Simulation of the flow system of Barton Springs and associated Edwards aquifer in the Austin area, Texas: U.S. Geological Survey Water-Resources Investigations Report $85-4299,49 \mathrm{p}$.

Slade, R. M., Jr., Veenhuis, J. E., Dorsey, M. E., Gardiner, Heather, and Smith, A. E., 1983, Hydrologic data for urban studies in the Austin, Texas, metropolitan area, 1981: U.S. Geological Survey Open-File Report 83-44, 293 p. Slade, R. M., Jr., Veenhuis, J. E., Dorsey, M. E., Stewart, S. L., and Ruiz, L. M., 1984, Hydrologic data for urban studies in the Austin, Texas, metropolitan area, 1982: U.S. Geological Survey Open-File Report 84-061, 196 p.

St. Clair, A. E., 1979, Quality of water in the Edwards aquifer, central Travis County, Texas: Austin, University of Texas, unpublished M.S. thesis, $95 \mathrm{p}$.

Texas Department of Health, Division of Water Hygiene, 1977, Drinking-water standards governing drinking-water quality and reporting requirements for public water supply systems (revised November 1980): Texas Department of Heal th, $20 \mathrm{p}$.

Texas Department of Water Resources, 1981, Texas surface-water quality standards: Texas Department of Water Resources LP-71, 108 p.

Thrailkill, J., 1968, Chemical and hydrologic factors in the excavation of limestone caves: Geological Society of America Bulletin, v. 79, p. 19-46.

Twidwell, Steve, 1976, Water-quality evaluation of Barton Creek and Barton Springs: Texas Water Quality Board Special Report SR-6, 23 p.

University of Texas, Bureau of Economic Geology, 1974, Geologic atlas of Texas, Austin sheet: Austin, scale 1:250,000.

U.S. Department of Agriculture, 1974, Soil survey of Travis County, Texas: 123 p.

U.S. Environmental Protection Agency, 1976, National interim primary drinking water regulations: Office of Water Supply, EPA-570/9-76-003, 159 p.

..-.--, 1977a, National secondary drinking water regulations: Federal Register, v. 42 , no. 62 , pt. I, p. $17143-17147$. 
-.---, 1977b, Quality criteria for water, 1976: U.S. Government Printing Office, $256 \mathrm{p}$.

U.S. Geological Survey, 1983, Water resources data for Texas, water year 1982, v. 3: U.S. Geological Survey Water-Data Report TX-82-3, 491 p.

Winslow, A. G., and Kister, L. R., Jr., 1956, Saline water resources of Texas: U.S. Geological Survey Water-Supply Paper 1365, 105 p.

Woodruff, C. M., Jr., 1984, Water-budget analysis for the area contributing recharge to the Edwards aquifer, Barton Springs segment, in Woodruff, C. M., Jr., and Slade, R. M., Jr., eds., Hydrogeology of the Edwards aquifer-Barton Springs segment: Austin Geological Society Guidebook no. 6, p. 36-42.

Young, K. P., 1977, Guidebook to the Geology of Travis County: Austin, University of Texas, Student Geological Society, $171 \mathrm{p}$. 


\section{GLOSSARY}

The glossary is composed of three separate sections having the following subject-related matter:

Glossary I Geologic and hydrogeologic terms

Glossary II Surface-water and hydrologic-measurements related terms

Glossary III Water-quality related terms

Definitions used in these glossaries are derived from the following publications: American Geological Institute, 1980; Langbein and Iseri, 1960; Lohman, 1972; Monroe, 1970; and U.S. Geological Survey, 1983. 
alluvium or alluvial deposits - Sediments deposited by streams; includes floodplain deposits. aquifer - A formation, group of formations, or part of a formation that is water-bearing. An underground stratum that will yield water in sufficient quantity to be of value as a source of supply.

calcite - A common rock-forming mineral - $\mathrm{CaCO}_{3}$; it is the major constituent of Timestone.

cavernous porosity - A pore system having large, cavernous openings.

cone of depression - Depression of the potentiometric surface surrounding a discharging well which is more or less the shape of an inverted cone.

confined aquifer - artesian aquifer - An aquifer which is overlain (confined) by a relatively impermeable layer so that the water is under hydrostatic pressure. The water in an artesian well will rise above the top of the aquifer to the level of the potentiometric surface; however, the well may or may not flow. confining bed or formation - One which, because of its position and its low permeability relative to that of the aquifer, keeps the water in the aquifer under pressure.

dip of rocks - The angle or amount of slope at which a bed is inclined from the horizontal; direction is also expressed (such as 1 degree southeast; or 90 feet per mile southeast).

drawdown - The lowering of the potentiometric surface caused by pumping or flow. It is the difference, in feet, between the static level and the pumping level.

electric log - A geophysical log showing the electrical properties of the rocks and their fluid contents penetrated in a well. The electrical properties are natural potentials and resistivities to induced electrical currents, some of which are modified by the presence of the drilling mud in and near the borehole. fault - A fracture or fracture zone in a rock or body of rock, along which there has been displacement of the two sides relative to one another, parallel to the fracture.

fluvial - of or pertaining to a river or rivers; produced by the action of a stream or river.

formation - A body of rock that is sufficiently homogeneous or distinctive to be regarded as a mappable unit at scales of 1:25,000 or are traceable in the subsurface.

geophysical $\log$ - A graphic record of the measured or computed physical characteristics of the rock section encountered in a well, plotted as a continuous function of depth.

ground water - Water in the ground that is in the zone of saturation from which wells, springs, and seeps are supplied.

head, or hydrostatic pressure - The height of the water table or potentiometric surface above an arbi trary datum.

hydraulic conductivity - The rate at which a unit volume of water per unit time, will flow through a cross section of unit area, measured at right angles to the direction of flow, under a unit hydraulic gradient, usually expressed as a unit length per unit time.

hydraulic gradient - The slope of the potentiometric surface, usually given in feet per mile.

infiltration - The flow of a fluid into a substance through pores or small openings. It connotes flow into a substance in contradistinction to the word percolation, which connotes flow through a porous substance. 
outcrop - That part of a rock which appears at the 1 and surface.

percolation - The movement, under hydrostatic pressure, of water through the interstices of a rock or soil, except the movement through large openings such as caves.

permeable - Pervious or having a texture that permits water to move through it perceptibly under the head differences ordinarily found in subsurface water. A permeable rock has communicating interstices of capillary or super-capillary size.

porosity - The ratio of the aggregate volume of interstices (openings) in a rock or soil to its total volume, usually stated as a percentage.

potentiometric surface - In a water-table aquifer, the potentiometric surface is the water table. In a confined aquifer, the potentiometric surface is the level to which water will rise in tightly cased wells.

recharge - The process by which water is absorbed and is added to the zone of saturation. Al so used to designate the quantity of water that is added to the zone of saturation.

resistivity (electrical $\mathrm{log}$ ) - The resistance of the rocks and their fluid content penetrated in a well to induced electrical currents. Permeable rocks containing fresh water have high resistivities.

secondary porosity - The porosity developed in a rock after its deposition or emplacement, through such processes as solution or fracturing.

sinkhole - A circular depression in a karst area - its drainage is subterranean, and it is commonly funnel-shaped.

specific capacity - The rate of yield of a well per unit of drawdown, usually expressed as gallons per minute per foot of drawdown. If the yield is 250 gallons per minute and the drawdown is 10 feet, the specific capacity is 25 gallons per minute per foot.

specific yield - The quantity of water that an aquifer will yield by gravity if it is first saturated and then allowed to drain; the ratio expressed in percentage of the volume of water drained to volume of the aquifer that is drained. storage - The volume of water in an aquifer, usually given in acre-feet.

storage coefficient - The volume of water an aquifer releases from or takes into storage per unit of surface area of the aquifer per unit change in the component of head normal to that surface.

strike - The direction or trend taken by a structural surface, e.g., a bedding or fault plane, as it intersects the horizontal.

transmissivity - The rate at which water is transmitted through a unit width of the aquifer under a unit hydraulic gradient. It is the product of the hydraulic conductivity and the saturated thickness of the aquifer and usually is expressed as a unit area per unit time.

unconformity - A boundary between rock units that represents a period of nondeposition or erosion during formation, signifying a fundamental change in the environment or a tectonic event.

vug - A small cavity in a vein or in rock.

vugular porosity - Porosity resulting from the presence of openings (vugs) from the size of a small pea upwards; it is usually used with reference to limestones.

water level - Usually expressed as the altitude of the potentiometric surface above National Geodetic Vertical Datum of 1929. Under artesian conditions the water level may be below or above the land surface.

water table - The upper boundary of an unconfined zone of saturation.

water-table aquifer (unconfined aquifer) - An aquifer in which the water is unconfined; the upper surface of the zone of saturation is under atmospheric pressure only and the water is free to rise or fall in response to the changes 
in the volume of water in storage. A well penetrating an aquifer under watertable conditions becomes filled with water to the level of the water table.

yield of a well - The rate of discharge, usually expressed in gallons per iminute.

zone of sacuration - The zone in which the permeable rocks are saturated with water under hydrostatic pressure. Water in the zone of saturation will flow into a well and is called ground water. 
acre-foot (AC-FT, acre-ft) - A quantity of water required to cover 1 acre to a depth of 1 foot and is equivalent to 43,560 cubic feet, about 326,000 gallons, or 1,233 cubic meters.

cubic foot per second (CFS, $\mathrm{ft}^{3} / \mathrm{s}$ ) - The rate of discharge representing a volume of 1 cubic foot passing a given point during 1 second of time. This rate is equivalent to approximately 7.48 gallons per second, 448.8 gallons per minute, or 0.02832 cubic meters per second.

cubic foot per second per square mile (CFSM) - The average number of cubic feet of water flowing per second from each square mile of area drained, assuming that the runoff is distributed uniformly in time and area.

discharge - The volume of water (or more broadly, volume of fluid plus suspended sediment), that passes a given point within a given period of time.

mean discharge (MEAN) - The arithmetic mean of individual daily-mean discharges during a specific period.

instantaneous discharge - The discharge at a particular instant of time. drainage area - A drainage area of a stream at a specified location is that area, measured in a horizontal plane, enclosed by a topographic divide from which direct surface runoff from precipitation normally drains by gravity into the stream upstream from the specified location.

drainage basin - A part of the surface of the earth that is occupied by a drainage system, which consists of a surface stream or a body of impounded surface water together with all tributary surface streams and bodies of impounded surface water.

evaporation - The process by which water is changed from the liquid or the solid state into the vapor state. In hydrology, evaporation is vaporization that takes place at a temperature below the boiling point.

evapotranspiration - Water withdrawn from a land area by evaporation from water surfaces and moist soil and plant transpiration.

gage height (G.HT.) - The water-surface elevation referred to some arbitrary gage datum. Gage height is often used interchangeably with the more general term "stage," al though gage height is more appropriate when used with a reading on a gage.

gaging station - A particular site on a stream, canal, lake, or reservoir where systematic observations of hydrologic data are obtained.

hydrograph - A graph showing stage, discharge, velocity, or other properties of water with respect to time.

intermittent stream - One which flows only at certain times of the year when it receives water from springs or from some surface source.

micrograms per $1 i$ ter $(U G / L, \mu \mathrm{g} / \mathrm{L})$ - A unit for expressing the concentration of chemical constituents in solution as mass (micrograms) of solute per unit volume (1iter) of water. One thousand micrograms per liter is equivalent to 1 milligram per 1iter.

milligrams per liter $(\mathrm{MG} / \mathrm{L}, \mathrm{mg} / \mathrm{L})$ - A unit for expressing the concentration of chemical constituents in solution. Milligrams per liter represent the mass of solute per unit volume (1iter) of water. Concentration of suspended sediment also is expressed in $\mathrm{mg} / \mathrm{L}$, and is based on the mass of sediment per liter of water-sediment mixture.

National Geodetic Vertical Datum of 1929 (NGVD of 1929) - A geodetic datum derived from a general adjustment of the first-order level nets of both the United States and Canada, formerly called "mean sea level." 
runoff - That part of the precipitation that appears in surface streams. It is the same as streamflow unaffected by artificial diversions, storage, or other works of man in or on the stream channels.

runoff in inches (IN, in.) - Shows the depth to which the drainage area would be covered if alt the runoff for a given time period were uniformly distributed on it.

steady flow - 0ccurs when the discharge at a given point remains unchanged with time.

streamflow - Is the discharge that occurs in a natural channel. Although the term "discharge" can be applied to the flow of a canal, the word "streamflow" uniquely describes the discharge in a surface stream course. The term "streamflow" is more general than "runoff" as streamflow may be applied to discharge whether or not it is affected by diversion or regulation.

transpiration - The quantity of water absorbed and transpired and used directly in the building of plant tissue, in a specified time. It does not include soil evaporation. The process by which water vapor escapes from the living plant, principally the leaves, and enters the atmosphere.

unsteady flow - Occurs when the discharge at a given point changes with time. watershed - Drainage basin. 


\section{GLOSSARY II I \\ Water-Quality Related Terms $1 /$}

bacteria - Microscopic unicellular organisms, typically spherical, rodlike, or spiral and threadlike in shape, often clumped into colonies. Some bacteria cause disease, others perform an essential role in nature in the recycling of materials; for example, by decomposing organic matter into a form available for reuse by plants.

total-coliform bacteria - A particular group of bacteria that are used as indicators of possible sewage pollution. They are characterized as aerobic or facultative anaerobic, gram-negative, nonspore-forming, rod-shaped bacteria which ferment lactose with gas formation within 48 hours at $35^{\circ} \mathrm{C}$. Their concentrations are expressed as number of colonies per 100 milliliters of sample. fecal-coliform bacteria - Bacteria that are present in the intestines or feces of warm-blooded animats. They are often used as indicators of the sanitary quality of the water. Their concentrations are expressed as number of colonies per 100 milliliters of sample.

fecal-streptococcal bacteria - Bacteria found in intestines of warm-blooded animals. Their presence in water is considered to verify fecal pollution.

They are characterized as gram-positive, cocci bacteria which are capable of growth in brain-heart infusion broth. Their concentrations are expressed as number of colonies per 100 milliliters of sample.

biochemical-oxygen demand (BOD) - A measure of the quantity of dissolved oxygen, in milligrams per liter, necessary for the decomposition of organic matter by microorganisms, such as bacteria.

dissolved - Refers to that material in a representative water sample which passes through a 0.45-micrometer membrane filter. This is a convenient operational definition used by Federal agencies that collect water data. Determinations of "dissolved" constituents are made on subsamples of the filtrate.

hardness - A physical-chemical characteristic of water that is commoniy recognized by the increased quantity of soap required to produce lather. It is attributable to the presence of alkaline earths (principally calcium and magnesium) and is expressed as equivalent calcium carbonate $\left(\mathrm{CaCO}_{3}\right)$.

specific conductance - A measure of the ability of a water to conduct an electrical current. It is expressed in microsiemens per centimeter at $25^{\circ} \mathrm{C}$. Specific conductance is related to the type and concentration of ions in solution and can be used for approximating the dissolved-solids concentration in the water. Commoniy, the concentration of dissolved solids (in milligrams per liter) is about 65 percent of the specific conductance (in microsiemens). This relation is not constant from well to well or from stream to stream, and it may vary in the same source with changes in the composition of the water.

suspended, total - Refers to the total amount of a given constituent in the part of a representative water-suspended sediment sample that is retained on a 0.45-micrometer membrane filter. This term is used only when the analytical procedure assures measurement of at least 95 percent of the constituent determined. A knowledge of the expected form of the constituent in the sample, as well as the analytical methodology used, is required to determine when the results should be reported as "suspended, total." Determinations of "sus-

17 A summary of standards for selected water-quality constituents and properties for public water systems is presented in table 8 . The source and significance of selected water-quality constituents and properties is presented in table 9. 
pended, total" constituents are made either by analyzing parts of the material collected on the filter or, more commonly, by difference, based on determinations of (1) dissolved and (2) total concentrations of the constituents.

turbidity - The reduction of transparency due to the presence of suspended particulate matter. Such material may consist of clay or silt, finely divided organic matter, plankton, or other microscopic organisms. 
SUPPLEMENTAL INFORMATION

(Tables 3 and 9)

$-105-$ 


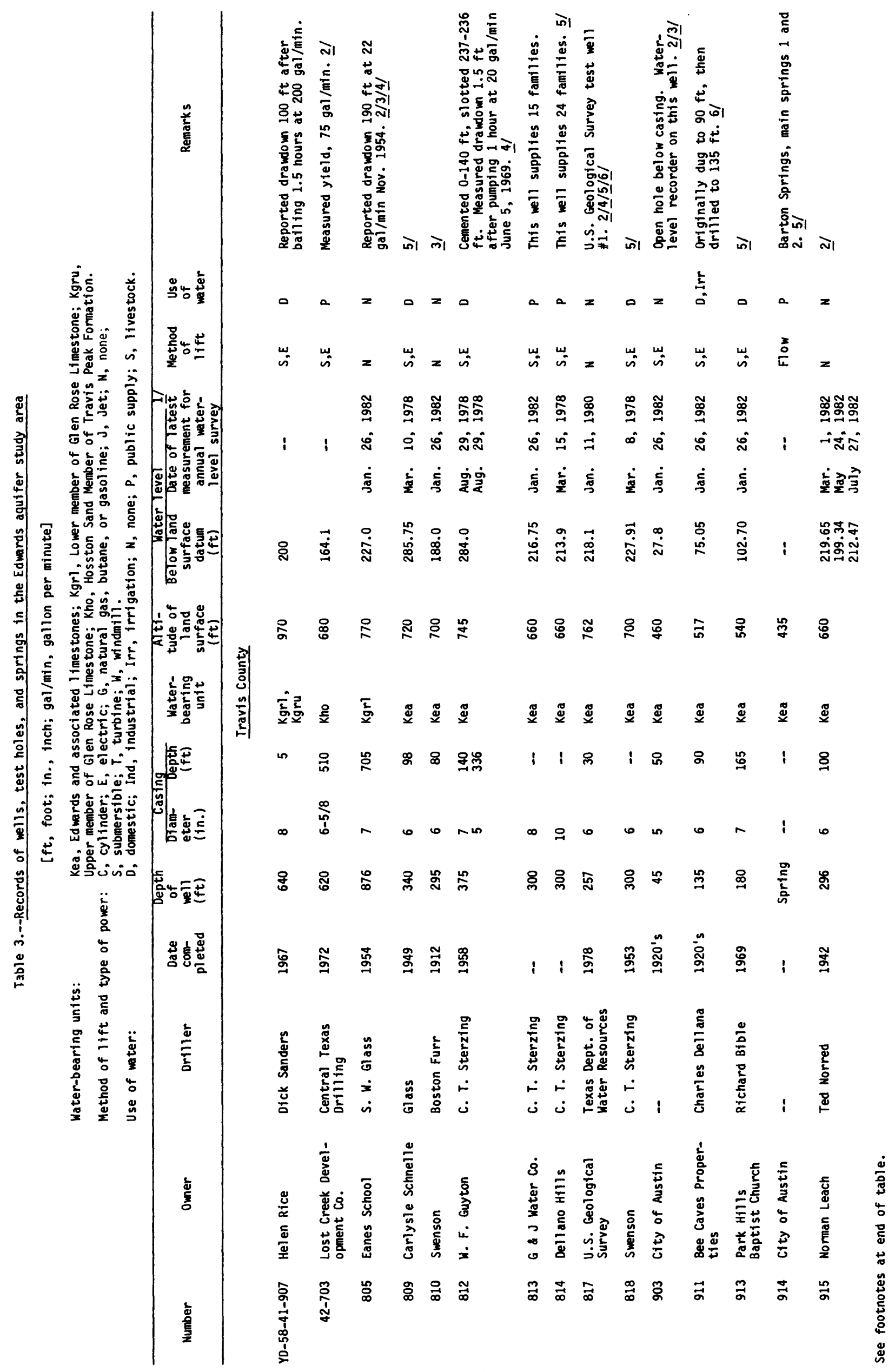




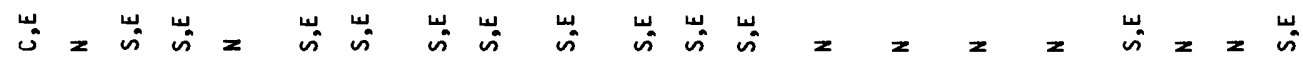

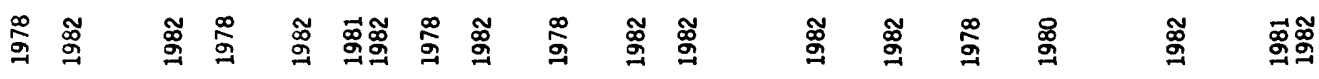
ذं।

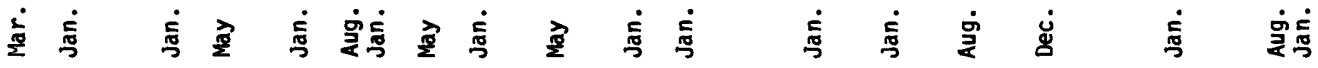

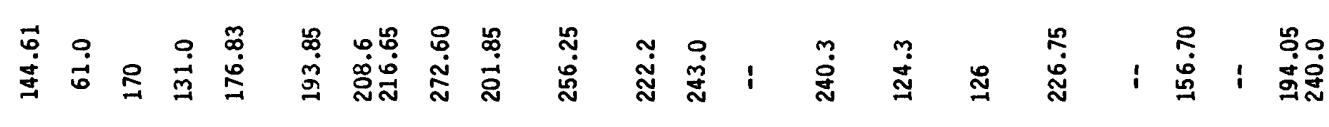

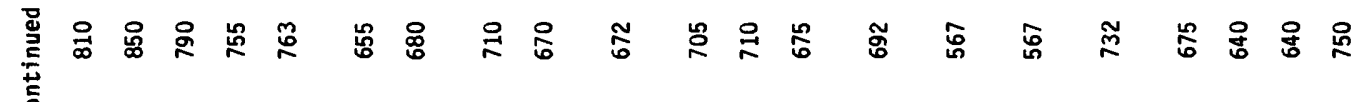

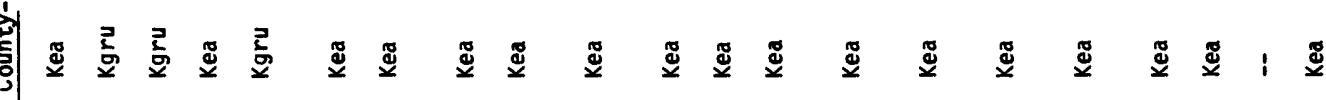

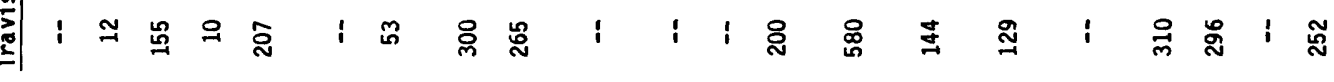

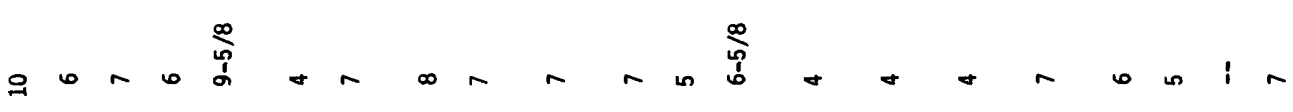

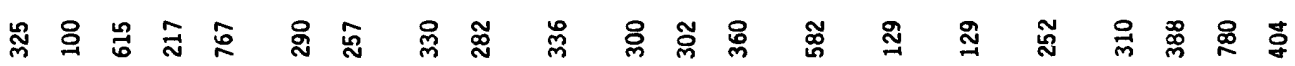

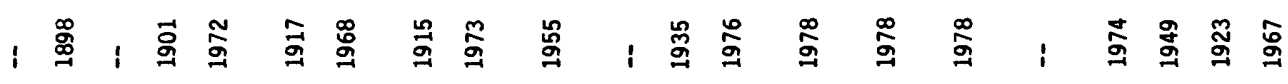

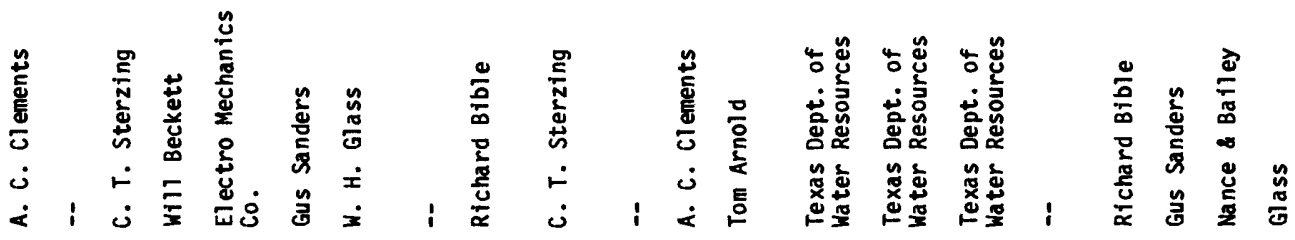

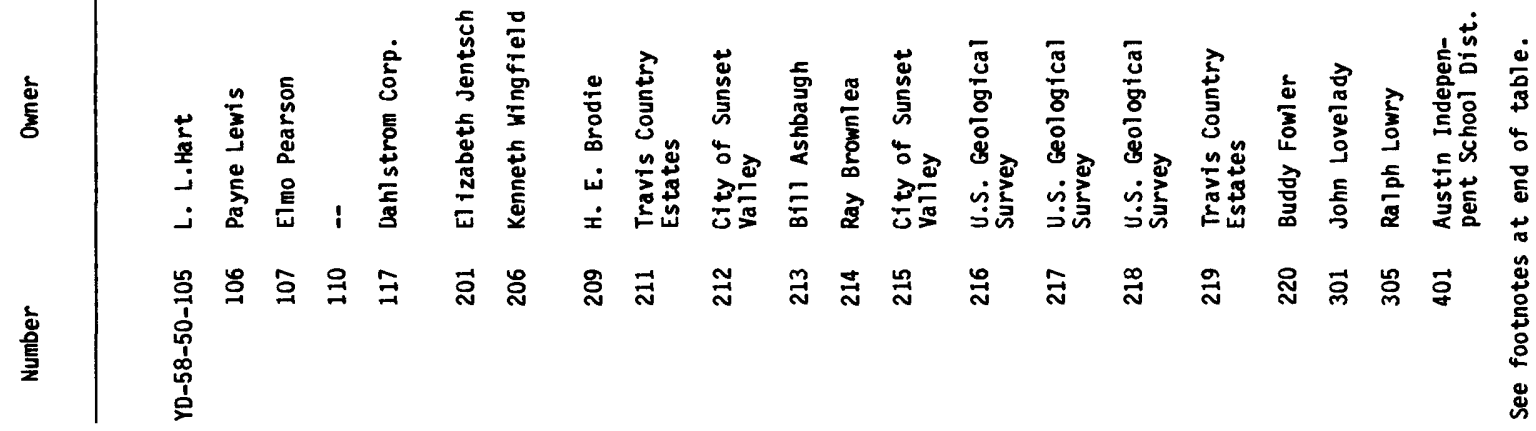




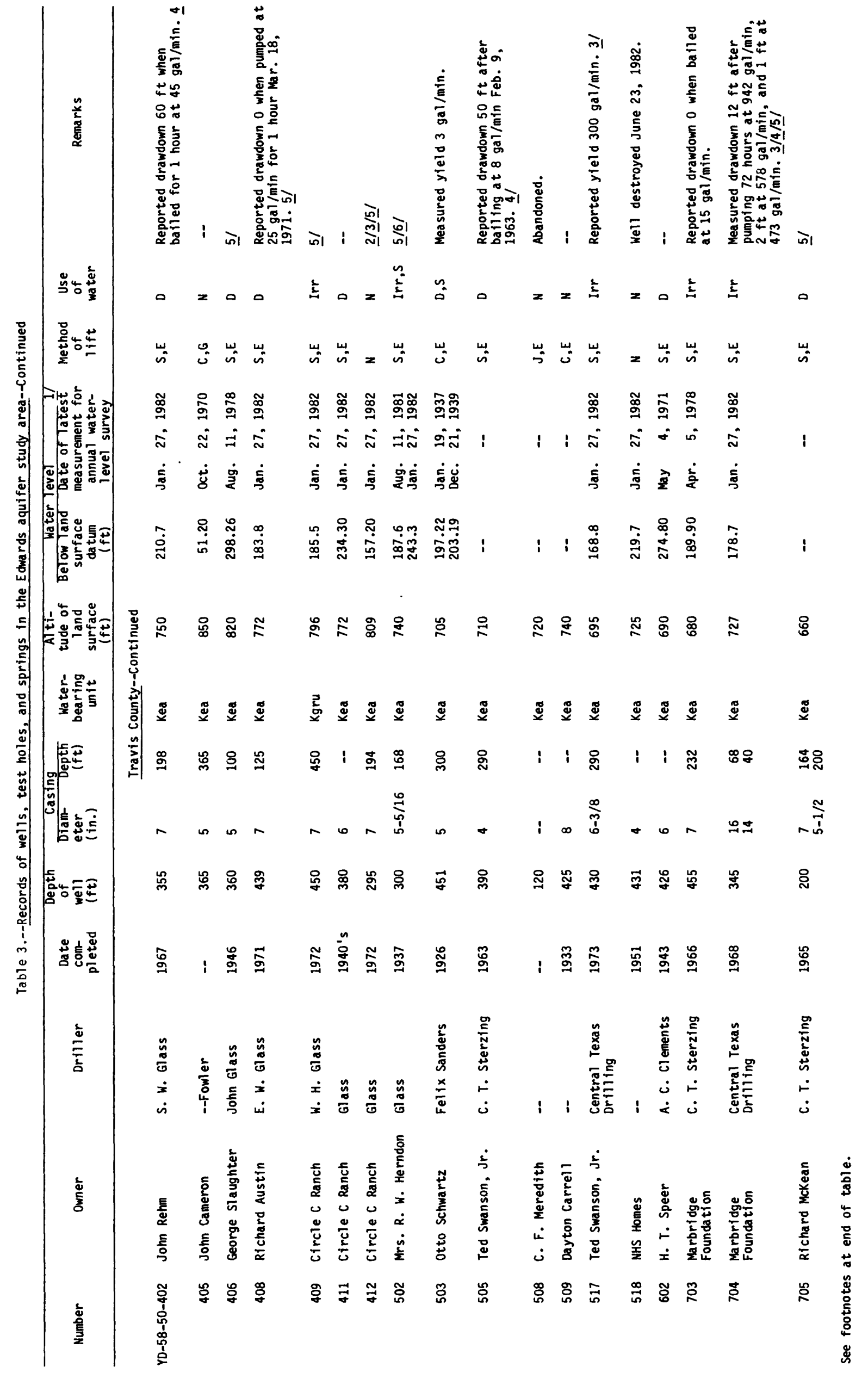




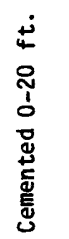

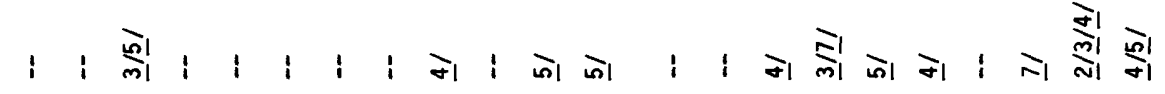

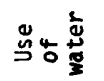

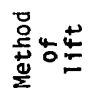

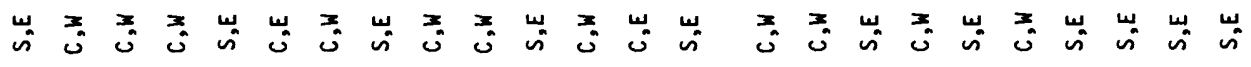

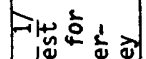

స

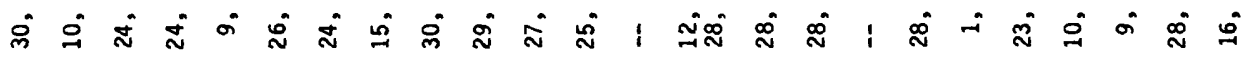

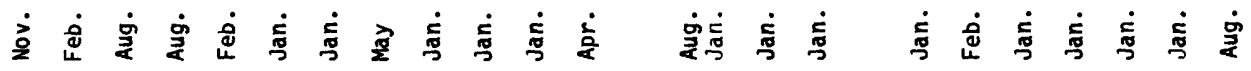
菅芒

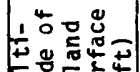

ڤ̊

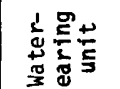

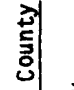

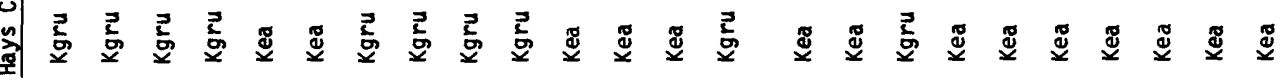

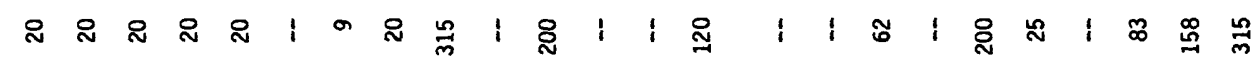

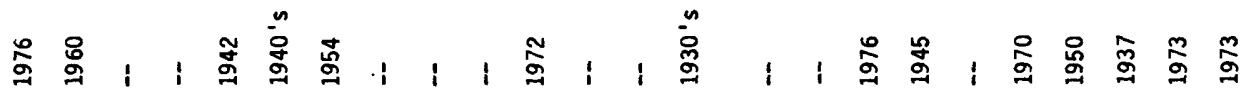

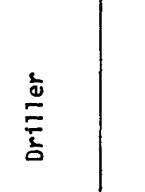

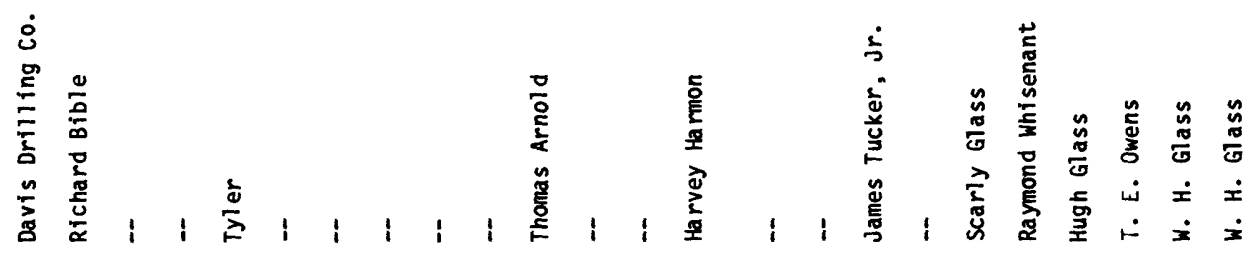

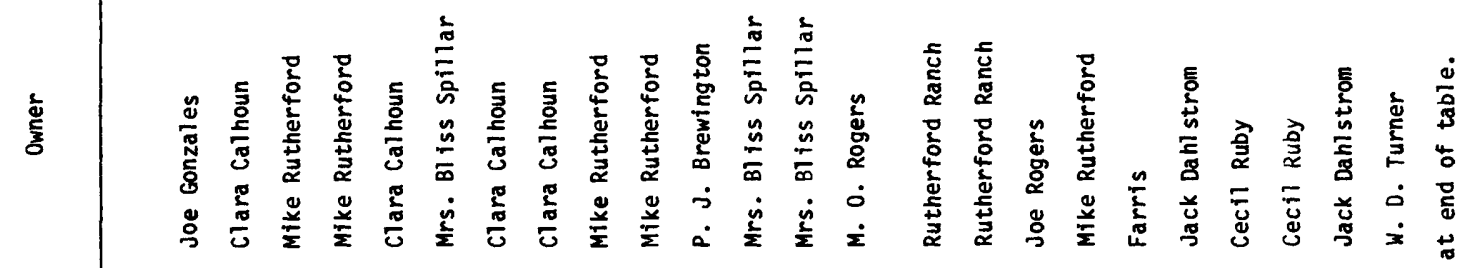

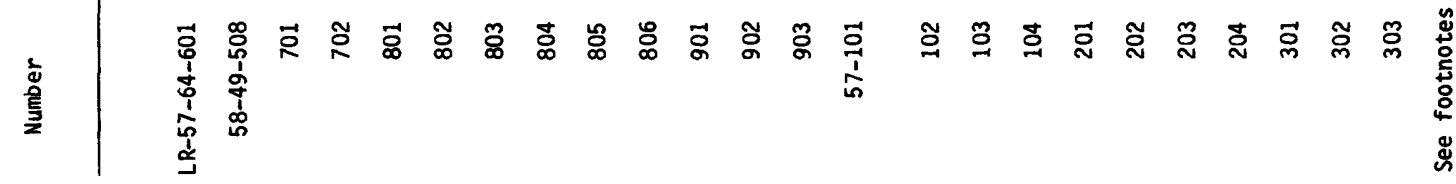




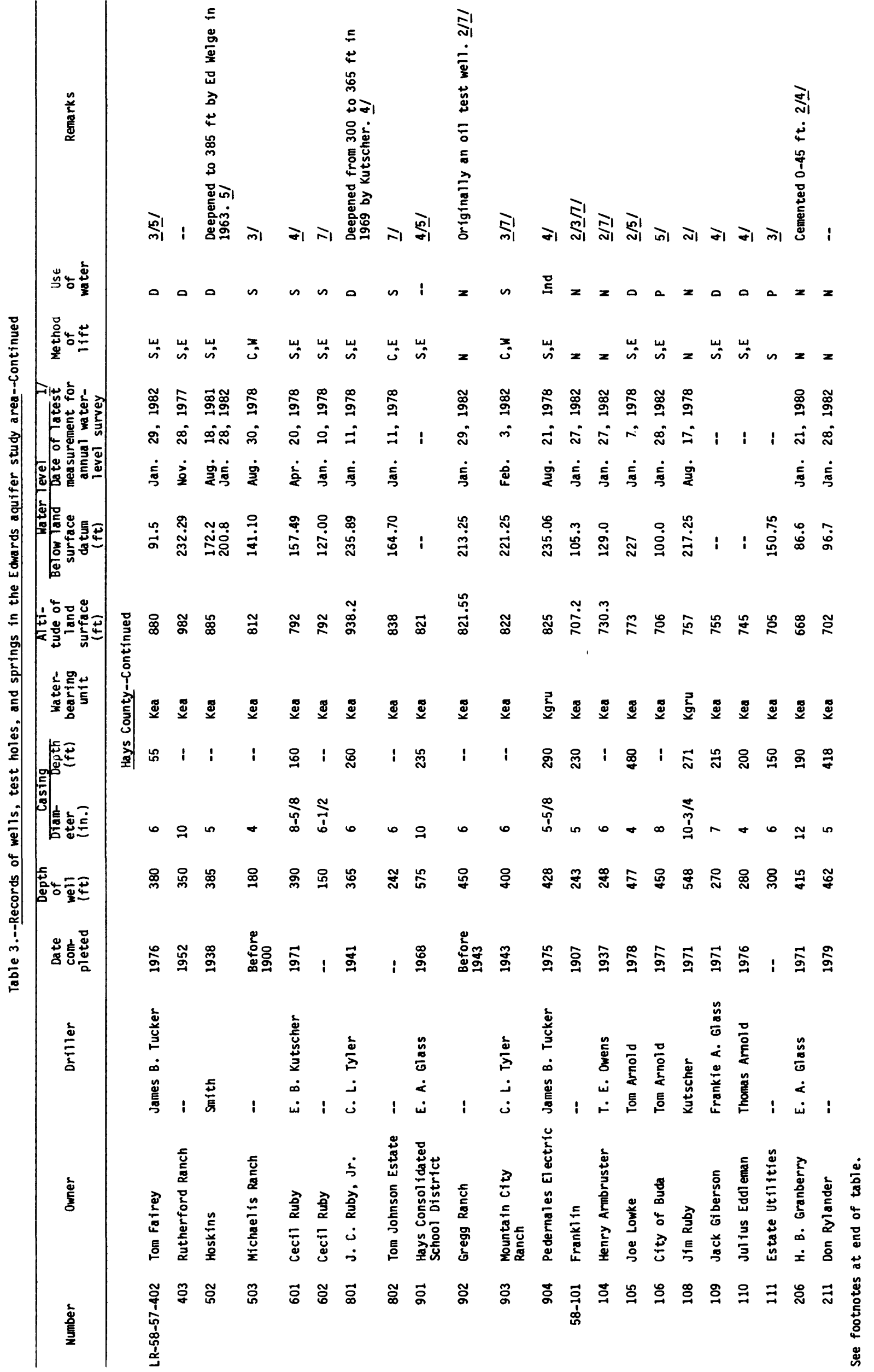




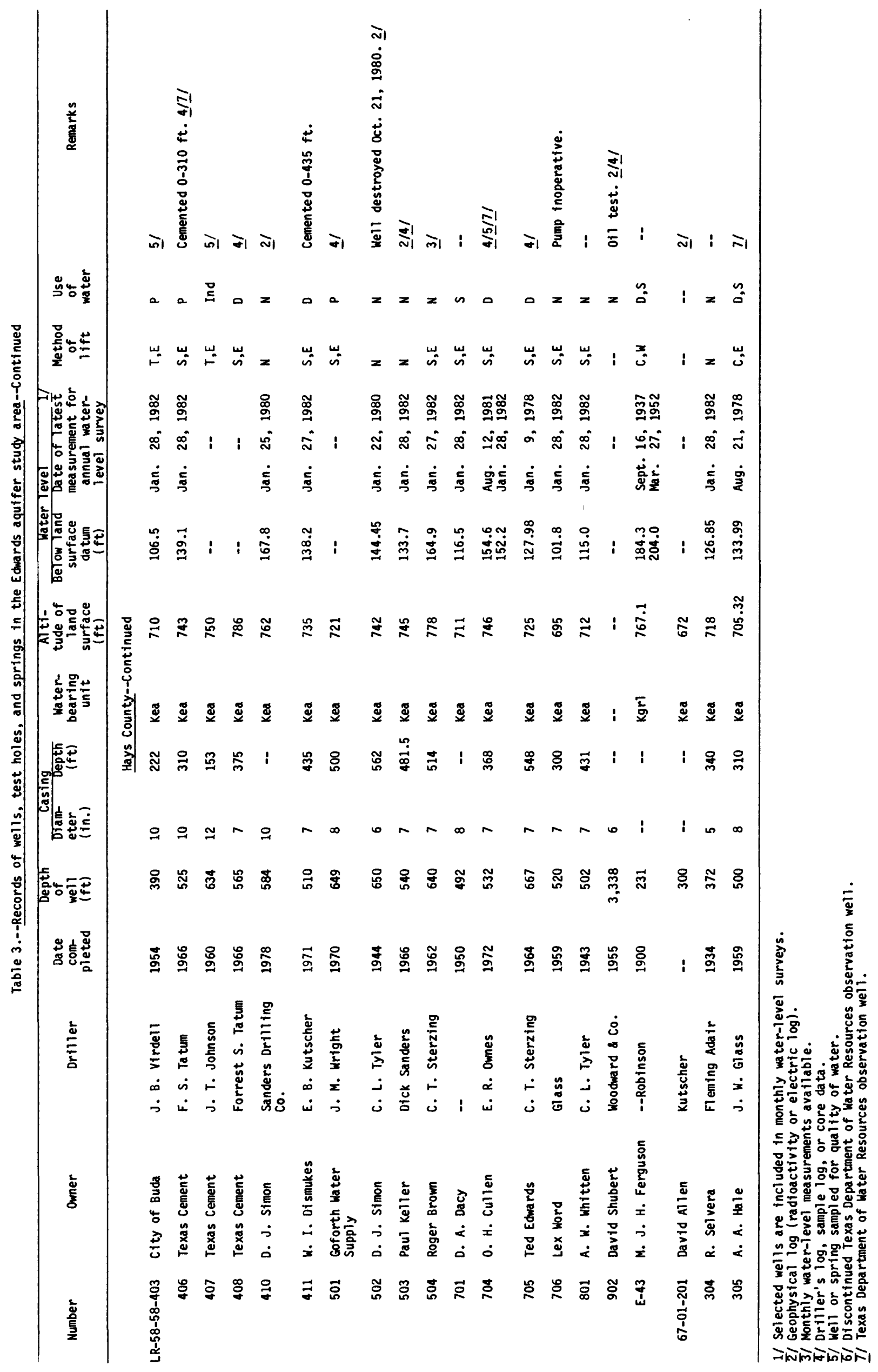


Table 9.--Source and significance of selected constituents and properties commonly reported in water analyses II

[mg/L, milligram per liter; $\mu \mathrm{g} / \mathrm{L}$, microgram per liter; microsiemens, microsiemens per centimeter at $25^{\circ}$ Celsius]

Constituent

or property

Silica

$\left(\mathrm{SiO}_{2}\right)$

Iron

(Fe)

Calcium

(Ca)

Magnesium

$(\mathrm{Mg})$

Sodium

(Na)
Source or cause

Significance
Silicon ranks second only to oxygen in abundance in the Earth's crust. Contact of natural waters with silica-bearing rocks and soils usually results in a concentration range of about 1 to 30 $\mathrm{mg} / \mathrm{L}$; but concentrations as 1arge as $100 \mathrm{mg} / \mathrm{L}$ are common in waters in some areas.

Iron is an abundant and widespread constituent of many rocks and soils. Iron concentrations in natural waters are dependent upon several chemical equilibria processes including oxidation and reduction; precipitation and solution of hydroxides, carbonates, and sulfides; complex formation especially with organic material; and the metabolism of plants and animals. Dissolved-iron concentrations in oxygenated surface waters seldom are as much as $1 \mathrm{mg} / \mathrm{L}$. Some ground waters, unoxygenated surface waters such as deep waters of stratified lakes and reservoirs, and acidic waters resulting from discharge of industrial wastes or drainage from mines may contain considerably more iron. Corrosion of iron casings, pumps, and pipes may add iron to water pumped from wells.

Calcium is widely distributed in the common minerals of rocks and soils and is the principal cation in many natural freshwaters, especially those that contact deposits or soils originating from limestone, dolomite, gypsum, and gypsiferous shale. Calcium concentrations in freshwaters usually range from zero to several hundred milligrams per liter. Larger concentrations are not uncommon in waters in arid regions, especially in areas where some of the more soluble rock types are present.

Magnesium ranks eight among the elements in order of abundance in the Earth's crust and is a common constituent in natural water. Ferromagnesian minerals in igneous rock and magnesium carbonate in carbonate rocks are two of the more important sources of magnesium in natural waters. Magnesium concentrations in freshwaters usually range from zero to several hundred milligrams per liter; but larger concentrations are not uncommon in waters associated with limestone or dolomite.

Sodium is an abundant and widespread constituent of many soils and rocks and is the principal cation in many natural waters associated with argillaceous sediments, marine shales, and evaporites and in sea water. Sodium salts are very soluble and once in solution tend to stay in solution. Sodium concentrations in natural waters vary from less than $1 \mathrm{mg} / \mathrm{L}$ in stream runoff from areas of high rainfall to more than $100,000 \mathrm{mg} / \mathrm{L}$ in ground and surface waters associated with halite deposits in arid areas. In addition to natural sources of sodium, sewage, industrial effluents, oilfield brines, and deicing salts may contribute sodium to surface and ground waters.
Although silica in some domestic and industrial water supplies may inhibit corrosion of iron pipes by forming protective coatings, it generally is objectionable in industrial supplies, particularly in boiler feedwater, because it may form hard scale in boilers and pipes or deposit in the tubes of heaters and on steamturbine blades.

Iron is an objectionable constituent in water supplies for domestic use because it may adversely affect the taste of water and beverages and stain laundered clothes and plumbing fixtures. According to the National Secondary Drinking Water Regulations proposed by the U.S. Environmental Protection Agency (1977a), the secondary maximum contamination level of iron for public water systems is $300 \mu \mathrm{g} / \mathrm{L}$. Iron al so is undesirable in some industrial water supplies, particularly in waters used in highpressure boilers and those used for food processing, production of paper and chemicals, and bleaching or dyeing of textiles.

Calcium contributes to the total hardness of water. Small concentrations of calcium carbonate combat corrosion of metallic pipes by forming protective coatings. Calcium in domestic water supplies is objectionable because it tends to cause incrustations on cooking utensils and water heaters and increases soap or detergent consumption in waters used for washing, bathing, and laundering. Calcium also is undesirable in some industrial water supplies, particularly in waters used by electroplating, textile, pulp and paper, and brewing industries and in water used in high-pressure boilers.

Magnesium contributes to the total hardness of water. Large concentrations of magnesium are objectionable in domestic water supplies because they can exert a cathartic and diuretic action upon unacclimated users and increase soap or detergent consumption in waters used for washing, bathing, and laundering. Magnesium also is undesirable in some industrial supplies, particularly in waters used by textile, puip and paper, and brewing industries and in water used in high-pressure boilers.

Sodium in drinking water may impart a salty taste and may be harmful to persons suffering from cardiac, renal, and circulatory diseases and to women with toxemias of pregnancy. Sodium is objectionable in boiler feedwaters because it may cause foaming. Large sodium concentrations are toxic to most plants; and a large ratio of sodium to total cations in irrigation waters may decrease the permeability of the soil, increase the pH of the soil solution, and impair drainage. 
Table 9.- Source and significance of selected constituents and properties commonly reported in water analyses--Continued

Constituent

or property

Potassium

(K)

1kalinity

Sulfate

$\left(\mathrm{SO}_{4}\right)$

Chloride

(C1)

Fluoride

(F)

Source or cause

Significance

Al though potassium is only slightly less common than sodium in igneous rocks and is more abundant in sedimentary rocks, the concentration of potassium in most natural waters is much smaller than the concentration of sodium. Potassium is 1 iberated from silicate minerals with greater difficulty than sodium and is more easily adsorbed by clay minerals and reincorporated into solid weathering products. Concentrations of potassium more than $20 \mathrm{mg} / \mathrm{L}$ are unusual in natural freshwaters, but much larger concentrations are not uncommon in brines or in water from hot springs.

Alkalinity is a measure of the capacity of a water to neutralize a strong acid, usually to $\mathrm{pH}$ of 4.5 , and is expressed in terms of an equivalent concentration of calcium carbonate $\left(\mathrm{CaCO}_{3}\right)$. Alkalinity in natural waters usually is caused by the presence ob bicarbonate and carbonate ions and to a lesser extent by hydroxide and minor acid radicals such as borates, phosphates, and silicates. Carbonates and bicarbonates are common to most natural waters because of the abundance of carbon dioxide and carbonate minerals in nature. Direct contribution to alkalinity in natural waters by hydroxide is rare and usually can be attributed to contamination. The alkalinity of natural waters varies widely but rarely exceeds 400 to $500 \mathrm{mg} / \mathrm{L}$ as $\mathrm{CaCO}_{3}$.

Sulfur is a minor constituent of the Earth's crust but is widely distributed as metallic sulfides in Igneous and sedimentary rocks. Weathering of metallic sulfides such as pyrite by oxygenated water yields sulfate ions to the water. Sulfate is dissolved al so from solls and evaporite sediments containing gypsum or anhydrite. The sulfate concentration in natural freshwaters may range from zero to several thousand milligrams per liter. Drainage from mines may add sulfate to waters by virtue of pyrite oxidation.

Chloride is relatively scarce in the Earth's crust but is the predominant anion in sea water, most petroleum-associated brines, and in many natural freshwaters, particularly those associated with marine shales and evaporites. Chloride salts are very soluble and once in solution tend to stay in solution. Chloride concentrations in natural waters vary from less than 1 $\mathrm{mg} / \mathrm{L}$ in stream runoff from humid areas to more than $100,000 \mathrm{mg} / \mathrm{L}$ in ground and surface waters associated with evaporites in arid areas. The discharge of human, animal, or industrial wastes and irrigation return flows may add significant quantities of chloride to surface and ground waters.

Fluoride is a minor constituent of the Earth's crust. The calcium fluoride mineral fluorite is a widespread constituent of resistate sediments and igneous rocks, but its solubility in water is negligible. Fluoride commonly is associated with volcanic gases, and volcanic emanations may be important sources of fluoride in some areas. The
Large concentrations of potassium in drinking water may impart a salty taste and act as a cathartic, but the range of potassium concentrations in most domestic supplies seldom cause these problems. Potassium is objectionable in boller feedwaters because it may cause foaming. In irrigation water, potassium and sodium act similarly upon the soil, al though potassium generally is considered less harmful than sodium.

Alkaline waters may have a distinctive unpleasant taste. Alkal inity is detrimental in several industrial processes, especially those involving the production of food and carbonated or acid-fruit beverages. The alkalinity in irrigation waters in excess of alkaline earth concentrations may increase the $\mathrm{pH}$ of the soil solution, leach organic material and decrease permeability of the soil, and impair plant growth.

Sulfate in drinking water may impart a bitter taste and act as a laxative on unacclimated users. According to the National Secondary Drinking Water Regulations proposed by the Environmental Protection Agency (1977a) the secondary maximum contaminant level of sulfate for public water systems is $250 \mathrm{mg} / \mathrm{L}$. Sulfate also is undesirable in some industrial supplies, particularly in waters used for the production of concrete, ice, sugar, and carbonated beverages and in waters used in high-pressure botlers.

Chloride may impart a salty taste to drinking water and may accelerate the corrosion of metals used in water-supply systems. According to the National Secondary Drinking Water Reguations proposed by the Environmental Protection Agency (1977a), the secondary maximum contaminant level of chloride for public water systems is $250 \mathrm{mg} / \mathrm{L}$. Chloride also is objectionable in some industrial supplies, particularly those used for brewing and food processing, paper and steel production, and textile processing. Chloride in irrigation waters generally is not toxic to most crops but may be injurious to citrus and stone fruits.

Fluoride in drinking water decreases the incidence of tooth decay when the water is consumed during the period of enamel calcification. Excessive quantities in drinking water consumed by children during the period of enamel calcification may cause a characteristic discoloration (mottling) of the teeth. According to the 
Table 9.--Source and significance of selected constituents and properties

commonly reported in water analyses--Continued

Constituent or property

Source or cause

Significance

Fluoride-Cont.

Nitrogen

(N)

Phosphorus (P)

Dissolved solids fluoride concentration in fresh surface waters usually is less than $1 \mathrm{mg} / \mathrm{L}$; but larger concentrations are not uncommon in saline water from oil wells, ground water from a wide variety of geologic terranes, and water from areas affected by volcanism.
A considerable part of the total nitrogen of the Earth is present as nitrogen gas in the atmosphere. Small amounts of nitrogen are present in rocks, but the element is concentrated to a greater extent in soils or biological material. Nitrogen is a cyclic element and may occur in water in several forms. The forms of greatest interest in water in order of increasing oxidation state, include organic nitrogen, ammonia nitrogen $\left(\mathrm{NH}_{4}-\mathrm{N}\right)$, nitrite nitrogen $\left(\mathrm{NO}_{2}-\mathrm{N}\right)$ and nitrate nitrogen $\left(\mathrm{NO}_{3}-\mathrm{N}\right)$. These forms of nitrogen in water may be derived naturally from the leaching of rocks, soils, and decaying vegetation; from rainfall; or from biochemical conversion of one form to another. Other important sources of nitrogen in water include effluent from wastewater treatment plants, septic tanks, and cesspools and drainage from barnyards, feed lots, and fertilized fields. Nitrate is the most stable form of nitrogen in an oxidizing environment and is usually the dominant form of nitrogen in natural waters and in polluted waters that have undergone self-purification or aerobic treatment processes. Significant quantities of reduced nitrogen often are present in some ground waters, deep unoxygenated waters of stratified lakes and reservoirs, and waters containing partially stabilized sewage or animal wastes.

Phosphorus is a major component of the mineral apatite, which is widespread in igneous rock and marine sediments. Phosphorus al so is a component of household detergents, fertilizers, human and animal metabolic wastes, and other biological material. Al though small concentrations of phosphorus may occur naturally in water as a result of leaching from rocks, soils, and decaying vegetation, larger concentrations are likely to occur as a result of pollution.

Theoretically, dissolved solids are anhydrous residues of the dissolved substance in water. In reality, the term "dissolved solids" is defined by the method used in the determination. In most waters, the dissolved solids consist predominantly of silica, calcium, magnesium, sodium, potassium, carbonate, bicarbonate, chloride, and sulfate with minor or trace amounts of other inorganic and organic constituents. In regions of high rainfall and relatively insoluble rocks, waters may contain dissolved-solids concentrations of less than $25 \mathrm{mg} / \mathrm{L}$; but saturated sodium chloride brines in other areas may contain more than $300,000 \mathrm{mg} / \mathrm{L}$.

National Interim Primary Drinking Water Regulations established by the Environmental Protection Agency (1976) the maximum contaminant level of fluoride in drinking water varies from 1.4 to $2.4 \mathrm{mg} / \mathrm{L}$, depending upon the annual average of the maximum daily air temperature for the area in which the water system is located. Excessive fluoride is also objectionable in water supplies for some industries, particularly in the production of food, beverages, and pharmaceutical items.

Concentrations of any of the forms of nitrogen in water significantly greater than the local average may suggest poliution. Nitrate and nitrite are objectionable in drinking water because of the potential risk to bottle-fed infants for methemoglobinemia, a sometimes fatal illness related to the impairment of the oxygen-carrying ability of the blood. According to the National Interim Primary Drinking Water Regulations (U.S. Environmental Protection Agency, 1976), the maximum contaminant level of nitrate (as N) in drinking water is 10 $\mathrm{mg} / \mathrm{L}$. Although a maximum contaminant level for nitrite is not specified in the drinking water regulations, Appendix A to the regulations (U.S. Environmental Protection Agency, 1976) indicates that waters with nitrite concentrations (as $N$ ) greater than $1 \mathrm{mg} / \mathrm{L}$ should not be used for infant feeding. Excessive nitrate and nitrite concentrations are al so objectionable in water supplies for some industries, particularly in waters used for the dyeing of wool and silk fabrics and for brewing.

Phosphorus stimulates the growth of algae and other nuisance aquatic plant growth, which may impart undesirable tastes and odor to the water, become aesthetically unpleasant, alter the chemistry of the water supply, and affect water treatment processes.

Dissolved-solids values are used widely in evaluating water quality and in comparing waters. The following classification based on the concentratrations of dissolved solids commonly is used by the Geological Survey (Winslow and Kister, 1956).

Classification Fresh

slightly sal ine Moderately saline

Very saline

Brine

The National Secondary Drinking Regulations

(U.S. Environmental Protection Agency, 1977a) 
Table 9.--Source and significance of selected constituents and properties commonly reported in water analyses--Continued

\section{Constituent} or property

Dissolved-

sol ids--

Cont.

Specific conductance (microsiemens)

Hardness as $\mathrm{CaCO}_{3}$
Specific conductance is a measure of the ability of water to transmit an electrical current and depends on the concentrations of ionized constituents dissolved in the water. Many natural waters in contact only with granite, well-leached soil, or other sparingly soluble material have a conductance of less than 50 microsiemens. The specific conductance of some brines exceed several hundred thousand micromhos.

Hardness of water is attributable to all polyvalent metals but principally to calcium and magnesium ions expressed as $\mathrm{CaCO}_{3}$ (calcium carbonate). Water hardness results naturally from the solution of calcium and magnesium, both of which are widely distributed in common minerals of rocks and soils. Hardness of waters in contact with limestone commonly exceeds $200 \mathrm{mg} / \mathrm{L}$. In waters from gypsiferous formations, a hardness of $1,000 \mathrm{mg} / \mathrm{L}$ is not uncommon.
The $\mathrm{pH}$ of a solution is a measure of its hydrogen ion activity. By definition, the $\mathrm{pH}$ of pure water at a temperature of $25^{\circ} \mathrm{C}$ is 7.00 . Natural waters contain dissolved gases and minerals, and the $\mathrm{pH}$ may deviate significantly from that of pure water. Rainwater not affected significantly by atmospheric pollution generally has a $\mathrm{pH}$ of 5.6 due to the solution of carbon dioxide from the atmosphere. The $\mathrm{pH}$ range of most natural surface and ground waters is about 6.0 to 8.5. Many natural waters are slightly basic ( $\mathrm{pH}$ $>7.0)$ because of the prevalence of carbonates and bicarbonates, which tend to increase the $\mathrm{pH}$. set a dissolved-solids concentration of 500 $\mathrm{mg} / \mathrm{L}$ as the secondary maximum contaminant level for public water systems. This level was set primarily on the basis of taste thresholds and potential physiological effects, particularly the laxative effect on unacclimated users. A) though drinking waters containing more than $500 \mathrm{mg} / \mathrm{L}$ are undesirable, such waters are used in many areas where less mineralized supplies are not available without any obvious $i 11$ effects. Dissolved solids in industrial water supplies can cause foaming in boilers; interfere with clearness, color, or taste of many finished products; and accelerate corrosion. Uses of water for irrigation al so are limited by excessive dissolved-solids concentrations. Dissolved solids in irrigation water may adversely affect plants directly by the development of high osmotic conditions in the soil solution and the presence of phytoxins in the water or indirectly by their effect on soils.

The specific conductance is an indication of the degree of mineralization of a water and may be used to estimate the concentration of dissolved solids in the water.

Hardness values are used in evaluating water quality and in comparing waters. The following classification is commonly used by the Geological Survey.

$\begin{array}{ccl}\text { Hardness }\left(\mathrm{mg} / \mathrm{L} \text { as } \mathrm{CaCO}_{3}\right) & \text { Classification } \\ 00-60 & \text { Soft } \\ 61-120 & \text { Moderately hard } \\ 121-180 & \text { Hard } \\ >180 & \text { Very hard }\end{array}$

Excessive hardness of water for domestic use is objectionable because it causes incrustations on cooking utensils and water heaters and increased soap or detergent consumption. Excessive hardness is undesirable also in many industrial supplies. (See discussions concerning calcium and magnesium.)

The $\mathrm{pH}$ of a domestic or industrial water supply is significant because it may affect taste, corrosion potential, and water-treatment processes. Acidic waters may have a sour taste and cause corrosion of metals and concrete. The National Secondary Drinking Water Regulations (U.S. Environmental Protection Agency, 1977a) set a $\mathrm{pH}$ range of 6.5 to 8.5 as the secondary maximum contaminant level for public water systems.

1/ Most of the material in this table has been summarized from several references. For a more thorough discussion of the source and significance of these and other water-quality properties and constituents, the reader is referred to the following additional references: American Public Health Association and others (1975); Hem (1970); McKee and Wolf (1963); National Academy of Sciences, National Academy of Engineering (1973); National Technical Advisory Committee to the Secretary of the Interior (1968); Texas Department of Health, Division of Water Hygiene (1977); Texas Department of Water Resources (1981); and U.S. Environmental Protection Agency (1977b). 